\title{
NÍVEIS DE NITROGÊNIO EM ARROZ PRÉ-GERMINADO
}

\section{OMAR VIEIRA VILLELA}

Engenheiro Agrônomo

Orientador: Dr. GERALDO JOSÉ APARECIDO DARIO

Dissertação apresentada à Escola Superior de Agricultura "Luiz de Queiroz", da Universidade de São Paulo, para obtenção do título de Mestre em Agronomia, Área de Concentração: Fitotecnia.

PIRACICABA

Estado de São Paulo - Brasil

fevereiro - 2000 
Dados Internacionais de Catalogação na Publicação (CIP) DIVISÃo DE BIBLIOTECA E DOCUMENTAÇÃO - Campus "Luiz de Queiroz"/USP

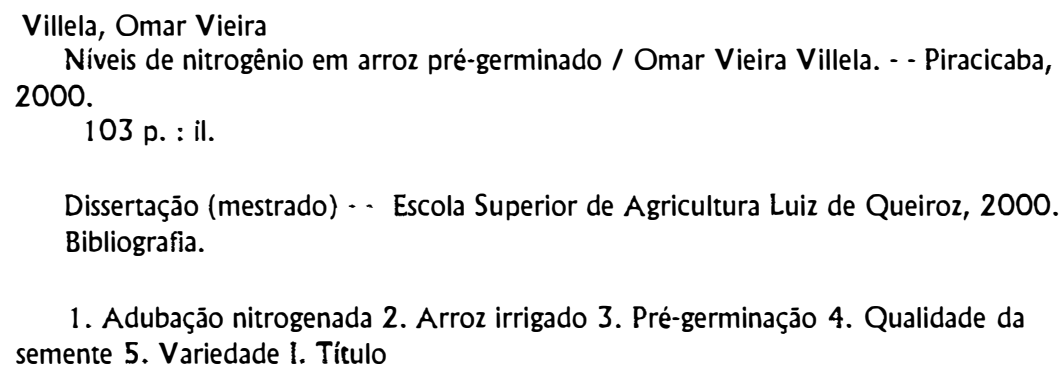

CDD 633.18

"Permitida a cópia total ou parcial deste documento, desde que citada a fonte - O autor" 


\author{
À minha esposa Vera Alice \\ e meus filhos Daniel e Felipe \\ pelo amor, dedicação, solidariedade e estímulo \\ DEDICO
}

Aos meus pais Gélio e Cornélia

(in memorian)

pelo exemplo de vida 


\section{Agradecimentos}

Aos funcionários da Estação Experimental de Agronomia de Pindamonhangaba, pelo esmero e dedicação.

Aos colegas de trabalho do Instituto Agronômico, pela cooperação.

Ao Professor Doutor Geraldo José Aparecido Dario, pelo apoio e amizade.

À Secretaria de Agricultura e Abastecimento e ao Instituto Agronômico, pela oportunidade de aperfeiçoamento. 


\section{SUMÁRIO}

LISTA DE TABELAS $\ldots \ldots \ldots \ldots$

Página

2.1. Efeitos do N sobre os componentes da produção de grãos de arroz .......... 6

2.2. Efeitos do $\mathrm{N}$ sobre o rendimento de arroz .......................................... 7

2.3. Efeitos do $\mathrm{N}$ sobre a qualidade de grãos de arroz ............................... 11

2.4. Efeitos do $\mathrm{N}$ sobre a qualidade de sementes de arroz .......................... 12

2.5. Eficiência e utilização do $\mathrm{N}$ pelas plantas de arroz ................................ 12

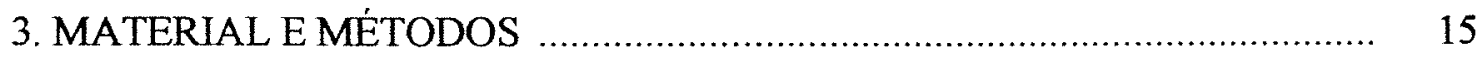

3.1. Local do Experimento .......................................................... 15

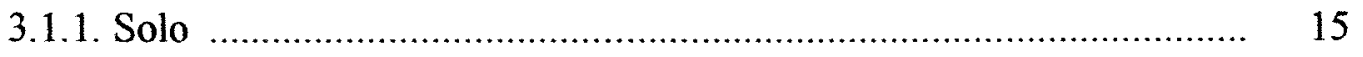

3.1.2. Clima …......................................................................... 16

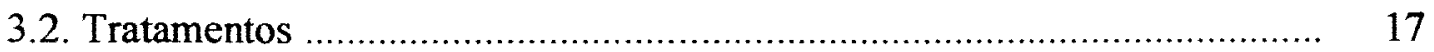

3.2.1. Cultivares de arroz (Fator A) ............................................. 17

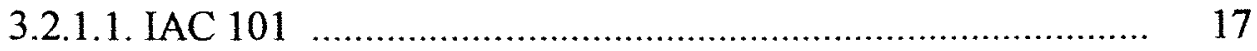

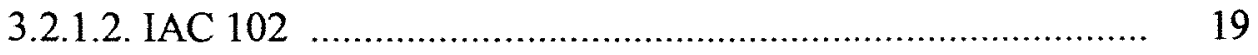

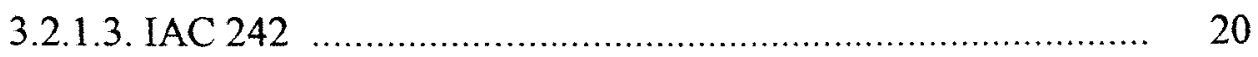

3.2.2. Níveis de nitrogênio (Fator B) ............................................ 21

3.2.2.1. Fonte de nitrogênio ..................................................... 22

3.3. Delineamento experimental ........................................................ 22

3.4. Instalação e condução do experimento ............................................. 23

3.4.1. Preparo do solo .................................................................... 23

3.4.2. Adubação de plantio ........................................................ 25 
3.4.3. Controle de plantas daninhas ..................................................... 25

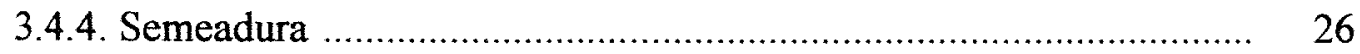

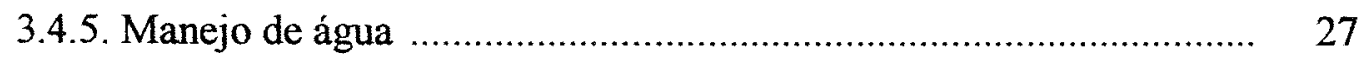

3.4.6. Colheita e preparo de sementes ................................................... 27

3.4.7. Análises Estatísticas ................................................................... 28

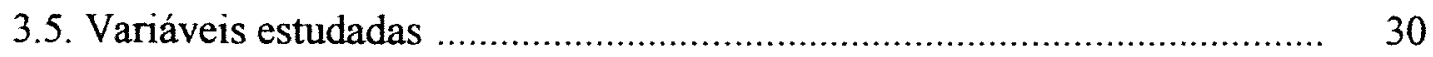

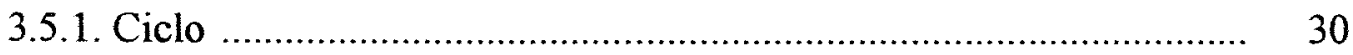

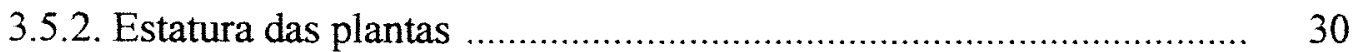

3.5.3. Número de panículas $/ \mathrm{m}^{2}$..................................................... 31

3.5.4. Comprimento de panícula .......................................................... 31

3.5.5. Número de grãos por panícula ...................................................... 31

3.5.6. Número de grãos granados por panícula ........................................ 31

3.5.7. Número de grãos fanados por panícula …….................................. 31

3.5.8. Peso de grãos por panícula .......................................................... 31

3.5.9. Peso de grãos granados por panícula ………………………......... 32

3.5.10. Peso de grãos fanados por panícula ............................................. 32

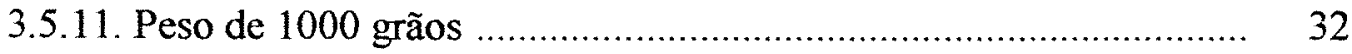

3.5.12. Dimensões dos grãos .............................................................. 32

3.5.13. Produção de grãos em casca ....................................................... 32

3.5.14. Rendimento de grãos no beneficiamento ..................................... 32

3.5.15. Produção de grãos inteiros beneficiados ...................................... 33

3.5.16. Produção de grãos quebrados benefíciados ................................. 33

3.5.17. Germinação das sementes .......................................................... 33

3.5.18. Vigor das sementes ............................................................ 34

3.5.19. Massa seca de 100 sementes .................................................... 34

3.5.20. Peso hectolítrico .................................................................... 34

4. RESULTADOS …...................................................................... 35

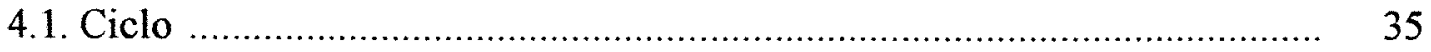




\section{Página}

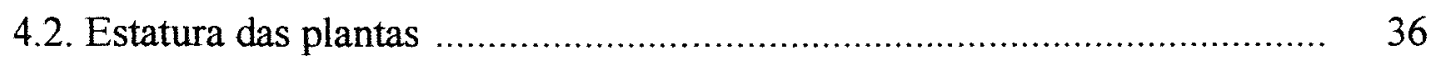

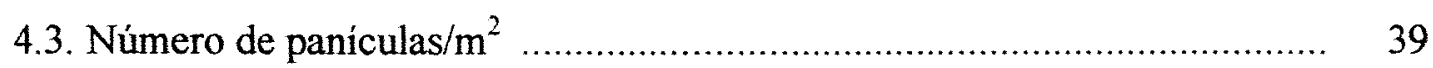

4.4. Comprimento da panícula ......................................................... 40

4.5. Número de espiguetas por panícula ................................................. 42

4.6. Número de grãos granados por panícula ........................................ 45

4.7. Número de grãos fanados por panícula .......................................... 48

4.8. Peso de grãos por panícula ............................................................ 50

4.9. Peso de grãos granados por panícula .............................................. 52

4.10. Peso de grãos fanados por panícula .......................................... 55

4.11. Peso de 1000 grãos ................................................................... 57

4.12. Dimensões dos grãos ............................................................ 59

4.12.1. Comprimento de grãos ................................................ 59

4.12.2. Largura de grãos …...................................................... 61

4.12.3. Espessura de grãos ..................................................... 62

4.13. Produção de grãos em $\mathrm{kg} / \mathrm{ha}$............................................................. 62

4.14. Rendimento de grãos no beneficiamento ....................................... 65

4.14.1. Peso de grãos inteiros beneficiados ................................... 65

4.14.2. Peso de grãos quebrados beneficiados ................................ 67

4.14.3. Renda do beneficiamento .................................................. 69

4.15. Produção de grãos inteiros beneficiados .......................................... 71

4.16. Produção de grãos quebrados beneficiados ..................................... 73

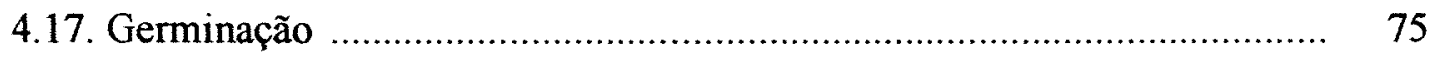

4.17.1. Plântulas normais ......................................................... 75

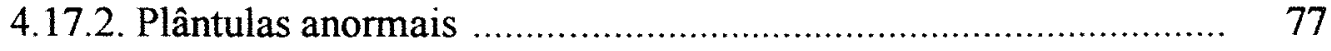

4.17.3. Plântulas infectadas ............................................... 78

4.17.4. Sementes mortas ........................................................ 80

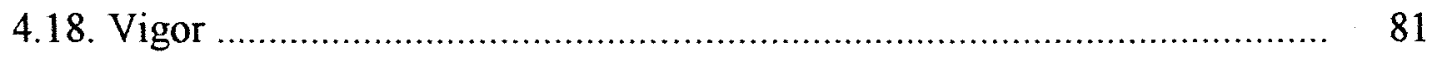

4.18.1. Plântulas normais ................................................... 81 
4.18.2. Plântulas anormais .............................................................. 82

4.18.3. Plântulas infectadas .............................................................. 83

4.18.4. Sementes mortas ................................................................ 84

4.19. Massa seca de 100 sementes ……………………........................... 85

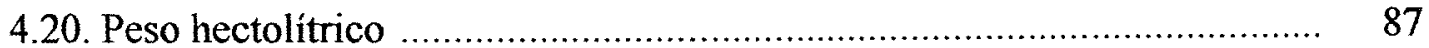

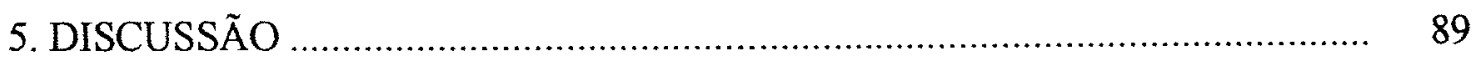

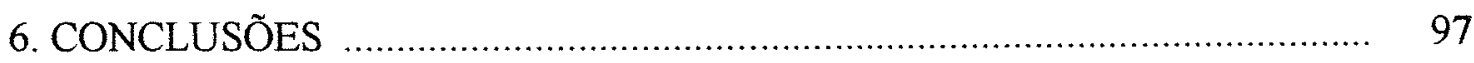

REFERÊNCIAS BIBLIOGRÁFICAS .......................................................... 98 


\section{LISTA DE TABELAS}

Página

Tabela 1. Normais climatológicas do município de Pindamonhangaba, período de 30 anos 


\section{LISTA DE QUADROS}

\section{Página}

Quadro 1. Esquema da análise da variância .................................................... 29

Quadro 2. Esquema da análise da regressão polinomial .................................. 30

Quadro 3. Dados médios de ciclo, em dias ..................................................... 36

Quadro 4. Médias de estatura, em $\mathrm{cm}$, para 12 tratamentos ............................. 37

Quadro 5. Médias de número de panículas $/ \mathrm{m}^{2}$, para 12 tratamentos .............. 39

Quadro 6. Médias de comprimento de panícula, em $\mathrm{cm}$, para 12

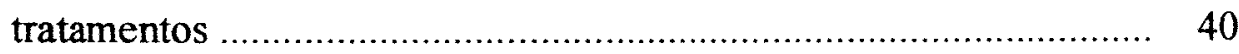

Quadro 7. Médias de número de espiguetas por panícula, para 12

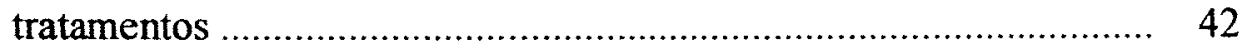

Quadro 8. Médias de número de grãos granados por panícula, para 12

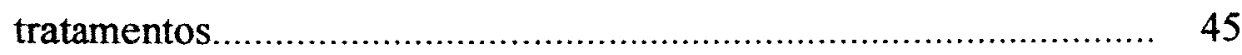

Quadro 9. Médias de número de grãos fanados por panícula, para 12

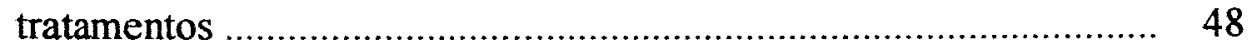

Quadro 10. Médias de peso de grãos por panícula, em gramas, para 12

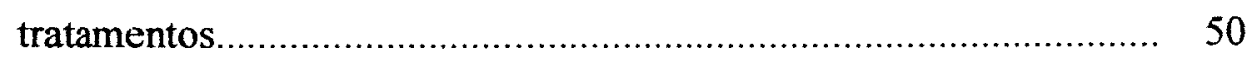

Quadro 11. Médias de peso de grãos granados por panícula, em gramas, para 12 tratamentos

Quadro 12. Médias de peso de grãos fanados por panícula, em gramas, para 12 tratamentos

Quadro 13. Médias de peso de 1000 grãos, em gramas, para 12 tratamentos

Quadro 14. Médias de comprimento de grãos, em milimetros, para 12 tratamentos 
Quadro 15. Médias de largura de grãos, em milímetros, para 12 tratamentos

Quadro 16. Médias de espessura de grãos, em milímetros, para 12 tratamentos

Quadro 17. Produção de arroz, em kg/ha, para 12 tratamentos

Quadro 18. Médias do peso de grãos inteiros beneficiados, em gramas, para 12 tratamentos

Quadro 19. Médias de peso de grãos quebrados beneficiados, em gramas, para 12 tratamentos

Quadro 20. Médias da renda do beneficiamento (peso de grãos inteiro mais peso de grãos quebrados), em gramas, para 12 tratamentos

Quadro 21. Produção de grãos inteiros de arroz, em $\mathrm{kg} / \mathrm{ha}$, para 12 tratamentos

Quadro 22. Médias de produção de grãos quebrados beneficiados, em $\mathrm{kg} / \mathrm{ha}$, para 12 tratamentos

Quadro 23. Porcentagens médias de plântulas normais, para 12 tratamentos transformados em arco seno $\sqrt{ } \mathrm{x} / 100$

Quadro 24. Porcentagens médias de plântulas anormais, para 12 tratamentos transformados em arco seno $\sqrt{x}_{\mathrm{x}} / 100$

Quadro 25. Porcentagens médias de plântulas infectadas, para 12 tratamentos, transformados em arco seno $V_{x} / 100$

Quadro 26. Porcentagens médias de sementes mortas, para 12 tratamentos, transformados em arco seno $\sqrt{x}_{\mathrm{x}} / 100$ 
Quadro 27. Porcentagens médias de plântulas normais, para 12 tratamentos, transformados em arco seno $\sqrt{x} / 100$.

Quadro 28. Porcentagens médias de plântulas anormais, para 12 tratamentos, transformados em arco seno $\sqrt{x} / 100$

Quadro 29. Porcentagens médias de plântulas normais, para 12 tratamentos, transformados em arco seno $\sqrt{ } \mathrm{x} / 100$

Quadro 30. Porcentagens médias de sementes mortas, para 12 tratamentos, transformados em arco seno $\mathrm{V}_{\mathrm{x}} / 100$

Quadro 31. Médias de massa seca de 100 sementes, em gramas, para 12 tratamentos.

Quadro 32. Médias de peso hectolitrico, em gramas, para 12 tratamentos 


\section{LISTA DE FIGURAS}

Página

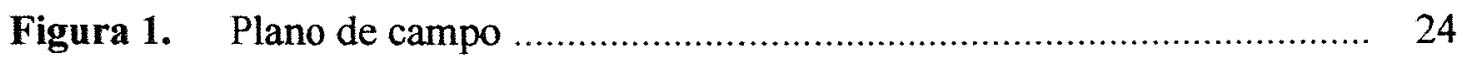

Figura 2. Curvas de resposta em estatura, dos cultivares estudados .............. 38

Figura 3. Curva de resposta do comprimento médio de panícula dos três cultivares de arroz irrigado aos quatro níveis de nitrogênio

Figura 4. Curva de resposta do número de grãos por panícula dos três cultivares aos quatro níveis de nitrogênio

Figura 5. Curva de resposta do número de grãos granados por panícula de três cultivares de arroz irrigado à quatro níveis de nitrogênio

Figura 6. Curva de resposta de grãos fanados por panícula de três cultivares de arroz irrigado, submetidos a quatro níveis de fertilização nitrogenada

Figura 7. Curva de resposta do peso médio de grãos por panícula de três cultivares aos quatro niveis de nitrogênio

Figura 8. Curvas de resposta do peso de grãos granados por panícula dos cultivares IAC 102 e IAC 242 .....

Figura 9. Curva de resposta do peso de grãos fanados por panícula dos três cultivares estudados 56

Figura 10. Curva de resposta, em peso de 1000 grãos, de três cultivares de arroz irrigado, submetidos a diferentes níveis de nitrogênio 58

Figura 11. Curva de resposta dos cultivares IAC 101, IAC 102 e IAC 242 aos quatro niveis de nitrogênio

Figura 12. Curva de resposta de produção de grãos em casca dos cultivares aos quatro níveis de nitrogênio 
Figura 13. Curva de resposta do peso de grãos inteiros beneficiados dos três cultivares de arroz aos quatro níveis de nitrogênio

Figura 14. Curva de resposta dos pesos de grãos quebrados beneficiados dos cultivares de arroz aos níveis crescentes de nitrogênio

Figura 15. Curva de resposta de produção de grãos inteiros beneficiados dos três cultivares aos quatro níveis de nitrogênio

Figura 16. Produções de grãos quebrados de três cultivares de arroz no beneficiamento

Figura 17. Médias de plântulas normais apresentadas pelos cultivares de arroz estudados

Figura 18. Médias de plântulas infectadas, apresentadas pelos cultivares estudados

Figura 19. Médias de massa seca de 100 sementes apresentadas pelos três cultivares de arroz estudados

Figura 20. Curva de resposta do peso hectolítrico dos três cultivares aos quatro niveis de nitrogênio 
xiii.

\section{NÍVEIS DE NITROGÊNIO EM ARROZ PRÉ-GERMINADO}

Autor: OMAR VIEIRA VILLELA

Orientador: DR. GERALDO JOSÉ APARECIDO DARIO

\section{RESUMO}

O presente trabalho teve como objetivo avaliar os efeitos de quatro niveis de nitrogênio aplicados ao solo sobre o rendimento de grãos, componentes da produção e qualidade de grãos e sementes de três cultivares de arroz irrigado, plantados pelo método de sementes pré-germinadas.

O experimento foi instalado em 8 de dezembro de 1996, em solo de várzea irrigada por inundação da Estação Experimental de Agronomia do Instituto Agronômico, no município de Pindamonhangaba, São Paulo, latitude $22^{\circ} 55^{\prime}$ sul, longitude $47^{\circ} 27^{\prime}$ oeste, e altitude de $560 \mathrm{~m}$.

Foram escolhidos os cultivares IAC 101, IAC 102 e IAC 242, submetidos à $0,50,100$ e $150 \mathrm{~kg}$ de $\mathrm{N} /$ ha na forma de uréia, aplicados em três épocas: $1 / 3$ no início do desenvolvimento das plantas, $1 / 3$ em pleno perfilhamento e $1 / 3$ na formação do primórdio floral. Adotou-se esquema fatorial com 12 tratamentos em blocos ao acaso com 3 repetições.

A fertilização nitrogenada influenciou positivamente a estatura das plantas, o número e o peso de grãos por panícula, o peso de 1000 grãos, as dimensões dos grãos, a produção de grãos e o rendimento de grãos inteiros no beneficiamento. 
O número de grãos granados por panícula foi o componente de produção que mais influenciou no aumento de rendimento de grãos.

As maiores respostas à fertilização nitrogenada ocorreram entre os níveis 0 e $50 \mathrm{~kg}$ de N/ha, e para níveis acima de $100 \mathrm{~kg}$ de N/ha ocorreu redução de eficiência de utilização de N.

O ciclo dos cultivares e as caracteristicas fisiológicas das sementes não foram influenciadas pela fertilização nitrogenada. 


\title{
LEVELS OF NITROGEN IN RICE PRE-GERMINATED
}

\author{
Author: OMAR VIEIRA VILLELA
}

Adviser: DR. GERALDO JOSÉ APARECIDO DARIO

\section{SUMMARY}

The present work had as objective to evaluate the effects of four applied rates of $\mathrm{N}(0,50,100$ and $150 \mathrm{~kg} / \mathrm{ha})$ to the soil surface, on the revenue of grain yield, yield components, grain and seed qualities of three irrigated rice cultivars (IAC 101, IAC 102 and IAC 242) planted by the method of pre-germinated seeds.

A series of studies was conducted at Pindamonhangaba Rice Research Station of the Agronomic Institute, in a low land Gley Humil Soil with latitude $22^{\circ} 55^{\prime} \mathrm{S}$, longitude $47^{\circ} 27^{\prime} \mathrm{W}$ and altitude of $560 \mathrm{~m}$. The $\mathrm{N}$ source was applied in a urea form split in three times: $1 / 3$ in the panicle initiation. The experimental design was in a factorial with 12 treatments in a randomized complete block with three replications.

Plant height, grains per panicle, percent of head rice, 1000 grain weight, grain shape and yield production were influenced positively by the $\mathrm{N}$ rate.

The best yield component to estimate the effect of $\mathrm{N}$ rate was filled grains, and the best response to the $N$ application occur between the rates 0 and $50 \mathrm{~kg} / \mathrm{ha}$, but rates over $100 \mathrm{~kg} /$ ha showed a reduction of nitrogen efficiency.

Cultivars growth duration and physiologic characteristics of the seeds were not influenced by the nitrogen fertilization. 


\section{INTRODUÇÃO}

O arroz é o principal componente da alimentação de aproximadamente $40 \%$ da população mundial, sendo produzido em mais de uma centena de países.

Ocupa uma área global em torno de 150 milhões de hectares, estando seu plantio concentrado no continente asiático, tendo a Índia e a República Popular da China como principais produtores e consumidores mundiais.

A produção mundial de arroz, de 270 milhões de toneladas em 1965, saltou para 540 milhões em 1990, devido principalmente a seleção de cultivares de nova arquitetura, que caracterizam-se pelo porte reduzido, alto perfilhamento, colmos fortes, folhas eretas, de coloração verde-escuras.

Entretanto nos últimos dez anos, os ganhos mundiais de produtividade de arroz diminuíram, encontrando-se próximos de $1 \%$, enquanto que a taxa de aumento das populações dos países consumidores de arroz é praticamente o dobro desse valor, indicando que no início do próximo século a demanda por arroz será maior que a produção. Assim, para inverter essa tendência é preciso cultivares com rendimentos mais elevados e práticas de manejo mais adequadas e dentre estas destaca-se o uso de fertilizantes nitrogenados.

No Brasil, segundo Chabarieberry \& Martins (1998), a situação não é diferente, com produção média no período de 1995 a 1998, de 9,3 milhões de toneladas para um consumo médio de 11,59 milhões de toneladas. 
Em São Paulo, de acordo com o Instituto de Economia Agrícola - IEA (1997), o arroz ocupa área de 80.000 hectares para uma produção de 170.000 toneladas, sendo desse total, 17.700 irrigados, produzindo 68.000 toneladas.

O Vale do Paraiba é o principal produtor de arroz irrigado do Estado de São Paulo, com 55.337 toneladas (safra de 1997/1998), produzidas em 13.500 hectares de várzea, distribuidos principalmente em áreas situadas às margens do Rio Paraíba. Nessas áreas predominam os métodos de semeadura mecanizada em solo drenado, utilizado desde o início do século quando o arroz foi introduzido na Região, e a semeadura de sementes pré-germinadas, amplamente adotada a partir dos meados da década de oitenta e que apresenta custos de produção mais reduzidos, maior eficiência no controle de plantas daninhas, e tem proporcionado ganhos de rendimento que podem ser ampliados pela utilização adequada de fertilizantes, pois observa-se com frequência em lavouras de arroz pré-germinado, sintomas de carência de nitrogênio como também áreas de acamamento, decorrentes do uso excessivo ou inadequado de fertilizantes nitrogenados.

É muito vasta a literatura sobre adubação nitrogenada, indicando que o arroz responde, quase que universalmente, às aplicações de nitrogênio, com incrementos no rendimento de grãos e na produção da matéria seca. Entretanto, no Estado de São Paulo, os poucos estudos que foram feitos nessa área, utilizaram cultivares de arroz de porte alto, com baixa capacidade de resposta à aplicação de nitrogênio, semeados em solo drenado, (Furlani et al., 1977; Hiroce et al., 1985; Leite et al., 1970a; Leite et al., 1970b; Leite et al., 1970c; Schmidt \& Gargantini, 1963; Schmidt \& Gargantini, 1966). 
O uso de cultivares modernos de arroz irrigado, de porte baixo, folhas eretas e elevada capacidade de perfilhamento, em experimentos de adubação nitrogenada no Vale do Paraíba foi adotado somente por Cantarella et al. (1986) pelo método de transplantio manual de mudas e por Perpétuo et al. (1989), utilizando semeadura em linhas em solo drenado.

Diante da necessidade de estudos regionais mais atualizados, propôs-se verificar os efeitos de quatro níveis de nitrogênio aplicado ao solo, sobre os componentes de produção, rendimentos de grãos, qualidade de grãos e qualidade de sementes de três cultivares de arroz irrigado recomendados para o Estado de São Paulo, (IAC 101, IAC 102 e IAC 242) plantados pelo método de sementes pré-germinadas. 


\section{REVISÃO DE LITERATURA}

A atmosfera, cuja composição o nitrogênio corresponde a aproximadamente $80 \%$, é a fonte natural desse nutriente, que é transferido para o solo e para as plantas superiores através dos processos de fixação simbiótica e fixação industrial, principalmente. Na planta, o nitrogênio tem as funções de componente da molécula de clorofila, aminoácidos, proteínas, enzimas, bases nitrogenadas (púricas e pirimídicas), vitaminas, coenzimas e pigmentos. Também é essencial para utilização dos carboidratos e estimula o desenvolvimento e a atividade das raizes, beneficiando a absorção de outros nutrientes.

Plantas com deficiência de nitrogênio apresentam clorose generalizada das folhas, iniciando-se pelas mais velhas. Estas apresentam efeito mais intenso da deficiência pela função estrutural do $\mathrm{N}$ na molécula de clorofila, que é degradada pela planta e retransloca o nitrogênio para regiões de crescimento ativo, em situação de restrição do fornecimento via solo.

A coloração amarelada das plantas deficientes em $\mathrm{N}$ está associada com a menor produção de clorofila e com modificações na forma de cloropastos.

Em arroz, além dos sintomas de deficiência de nitrogênio descritos, a lâmina da folha mais baixa morre da ponta para a base da folha, ficando o tecido morto com uma coloração chocolate. 
O nitrogênio é o nutriente que apresenta melhores efeitos sobre os rendimentos do arroz, podendo ser considerado como determinante de uma boa produção. Segundo Fageria (1984) o arroz necessita de nitrogênio durante a fase vegetativa para aumentar o número de perfilhos e, consequentemente o número de panículas. Durante a fase reprodutiva o nitrogênio aumenta o número de espiguetas por panícula e na maturação é importante para manter as folhas verdes para o processo de fotossíntese, consequentemente aumentando a porcentagem de grãos granados.

Heeman \& Bacon (1987) atribuem melhores rendimentos de colheita obtidos com aplicações mais tardias de $\mathrm{N}$ (iniciação da panícula) à maior porcentagem de grãos granados, comparados às produções resultantes de aplicações no início do ciclo, que causaram excesso de desenvolvimento vegetativo e auto-sombreamento.

De acordo com Furlani et al. (1977) e Hiroce et al. (1985), o nitrogênio é o terceiro nutriente mais absorvido pelo arroz, sendo no entanto o mais removido pela colheita, devido à maiores concentrações de $\mathrm{N}$ nos grãos em relação a colmos e folhas. Os autores observaram diferenças varietais para respostas aos niveis de $\mathrm{N}$ em relação à produção de grãos, acúmulo de matéria seca e quantidades absorvidas pelas plantas. Os percentuais de nitrogênio exportados pelas colheitas em relação ao $\mathrm{N}$ aplicado ao solo e absorvido pelas plantas, somados a outros fatores, evidenciam a necessidade de utilização de elevadas quantidades de $\mathrm{N}$ para obtenção de altos rendimentos de colheita. 


\subsection{Efeitos do N sobre os componentes da produção de grãos de arroz}

Iglesias \& Vargas (1980), em trabalho realizado na cidade de Palmira, Colombia, no qual foi testado o cultivar de arroz irrigado CICA 8, pelo método de transplantio manual de mudas, em quatro níveis de nitrogênio, de 0 a $200 \mathrm{~kg} / \mathrm{ha}$, observaram diferença significativa no rendimento de grãos entre os diferentes niveis de nitrogênio, com a maior produção para o nivel máximo. O número de panículas por unidade de área e o número de grãos granados por panícula, foram os componentes do rendimento de grãos mais influenciados pela aplicação de nitrogênio, com respostas positivas para níveis crescentes de nitrogênio. O peso de 1000 grãos produziu resposta significativa com aplicação de $150 \mathrm{~kg}$ de N/ha.

Mueller (1980), estudando o efeito de 5 níveis de nitrogênio sobre os cultivares de arroz irrigado E.E.A.-406, Bluebelle e BR IRGA-409, não verificou aumentos significativos de produção de grãos para os dois últimos, com apenas o primeiro cultivar apresentando produção máxima para $45 \mathrm{~kg}$ de N/ha. Constatou-se que os acréscimos de níveis de $\mathrm{N}$ aplicados induziram aumentos em estatura das plantas dos três cultivares estudados. As diferenças observadas no número de panículas por metro quadrado foram significativas apenas para cultivares. O comprimento das paniculas, o número de grãos por panícula e a porcentagem de grãos estéreis aumentaram com os acréscimos de nitrogênio. $O$ peso de 100 grãos não apresentou nenhum efeito significativo para os cultivares Bluebelle e BR IRGA-409 em função da variação de níveis de nitrogênio, enquanto que o cultivar E.E.A.-406 mostrou efeito negativo para niveis crescentes de N. Analisando estes resultados o autor concluiu ter havido uma compensação numérica entre os componentes do rendimento nos três cultivares estudados. 
Carvalho et al. (1995), estudando o efeito de 4 níveis de $\mathrm{N}$ sobre a produção de grãos e componentes da produção de 4 cultivares de arroz de sequeiro semeados em vaso em casa de vegetação, observaram que a estatura das plantas, comprimento das panículas, número de espiguetas por panícula e a produção de grãos, variou numa relação quadrática em função dos diferentes níveis de nitrogênio, havendo também diferenças significativas entre cultivares para essas variáveis. Os diferentes níveis de nitrogênio não influenciaram a porcentagem de grãos cheios, porém o peso 100 grãos apresentou um decréscimo linear com o aumento da dose de nitrogênio.

Andrade \& Amorim Neto (1996), em experimento de campo com os cultivares de arroz irrigado, INCA e PESAGRO 104, e 5 níveis de nitrogênio, entre 0 e $160 \mathrm{~kg}$ de $\mathrm{N} / \mathrm{ha}$, na forma de uréia, observaram respostas similares para ambos os cultivares, com efeito quadrático positivo para produção de grãos. A altura de plantas, o número de panículas por metro quadrado e o número de grãos cheios por panícula, também apresentaram incremento de valores para níveis crescentes de nitrogênio.

\subsection{Efeitos do $\mathrm{N}$ sobre o rendimento de arroz}

Schmidt \& Gargantini (1963), em estudo de diferentes épocas de aplicação do nitrogênio em arroz, no Vale do Paraíba, observaram grande reação da cultura, com aumento acentuado na estatura das plantas e produção de grãos. Os mesmos autores (1966), avaliando o efeito de 5 níveis de nitrogênio e 4 níveis de fósforo aplicados sobre o cultivar de arroz Iguape Agulha, verificaram aumentos lineares e significativos de produção de grãos somente para nitrogênio. 
LEITE et al. (1970a), estudando o efeito de 3 niveis de nitrogênio e 3 tipos de fertilizantes nitrogenados, em arroz irrigado em solo argiloso de várzea no Vale do Paraiba, obtiveram resultados que mostram grande efeito da adubação nitrogenada no aumento da produção do arroz. Em outros estudos os mesmos autores (1970b), testando os níveis de 0,40 e $80 \mathrm{~kg}$ de $\mathrm{N} / \mathrm{ha}$, em cultivares utilizados na mesma região, conduziram 13 experimentos em diversas localidades, abrangendo a maioria dos solos utilizados para a cultura do arroz irrigado e concluíram que o efeito do nitrogênio sobre a produção de grãos foi linear positivo, tanto nos solos orgânicos como nos solos argilosos, porém somente os últimos apresentaram efeito altamente significativo.

Ainda, Leite et al. (1970c), estudando os efeitos da adubação nitrogenada sobre a cultura do arroz irrigado em solos de várzea tipicamente argilosos, conduziram 6 experimentos em diferentes localidades no Vale do Paraíba, concluindo que 4 experimentos apresentaram respostas altamente significativas em produção de grãos à adubação nitrogenada.

Alvarenga et al. (1979), trabalhando com os cultivares de arroz IAC 435 (de porte alto) e IR 841 (porte baixo e folhas eretas), em 4 níveis de nitrogênio, de 0 a $160 \mathrm{~kg}$ de N/ha, concluíram que o cultivar IR 841 respondeu melhor à adubação nitrogenada do que o IAC 435, situando-se em torno de 65 e $85 \mathrm{~kg}$ de $\mathrm{N} / \mathrm{ha}$ respectivamente, os niveis de nitrogênio que propiciaram o máximo rendimento para os dois cultivares. Os autores observaram também que apenas o IAC 435 apresentou aumento da estatura das plantas, com incrementos dos niveis de nitrogênio, sendo que ambos os cultivares não apresentaram diferenças significativas quanto ao peso de 1000 grãos. O cultivar IR 841 mostrou efeito negativo de níveis crescentes de nitrogênio sobre o número de grãos por panícula, enquanto que o cultivar IAC 435 apresentou ganhos somente para $40 \mathrm{~kg}$ de N/ha. 
Valdivieso et al. (1980), estudando os cultivares CICA 8 e IR 22, duas distâncias de transplantio de mudas $(20 \times 20$ e $30 \times 30 \mathrm{~cm})$ e três níveis de nitrogênio $(0,80$ e $160 \mathrm{~kg} / \mathrm{ha})$ obtiveram resultados que mostraram efeitos positivos da adubação nitrogenada na produção de grãos. O cultivar CICA 8 foi superior ao $\operatorname{IR~} 22 \mathrm{em}$ todos os níveis de nitrogênio, porém ambos apresentaram drástica redução de ganhos de produção de grãos para níveis superiores a $80 \mathrm{~kg}$ de $\mathrm{N} / \mathrm{ha}$, nos dois espaçamentos estudados.

Hiroce et al. (1985) estudando os efeitos de 5 níveis de nitrogènio, fósforo e potássio sobre três cultivares de arroz, concluíram que o efeito da adubação nitrogenada na produção de grãos, de matéria seca da parte aérea nas diferentes fases de crescimento, e na concentração do respectivo nutriente nessas partes da planta, foi mais acentuado do que os efeitos isolados das adubações fosfatada e potássica, havendo também diferenças entre cultivares em relação as quantidades de nutrientes absorvidos.

Cantarella et al. (1986), utilizando cultivares modernos de arroz, de porte baixo e elevado perfilhamento, plantados pelo método de transplantio manual de mudas, verificaram ganhos significativos de produção de grãos para níveis de 0 a $180 \mathrm{~kg}$ de $\mathrm{N} / \mathrm{ha}$.

Perpétuo et al. (1989), em estudo de época de aplicação de nitrogênio sobre o cultivar de arroz irrigado IR 8-288-3, plantado pelo método de transplantio de mudas, durante 4 anos agrícolas, concluíram que a época mais adequada para aplicação do nitrogênio foi a distribuição de metade da dose no barro, junto com o fósforo e potássio, antes do transplantio das mudas de arroz, e outra metade no primórdio da panícula. 
Dario et al. (1989), estudando os efeitos de doses e épocas de aplicação de nitrogênio sobre o cultivar de arroz irrigado INCA, semeado em duas áreas de várzea, obtiveram resposta positiva para produção de grãos, em solo com alto teor de matéria orgânica e boa fertilidade, apenas para dose mínima de $\mathrm{N}$, não apresentando segundo os autores, viabilidade de adubação nitrogenada. Em outra área, submetida a grande movimentação de terra durante o processo de sistematização, os autores não encontraram significância entre os tratamentos para as variáveis: produção de grãos e componentes da produção.

Lopes (1989), utilizando 8 fertilizantes nitrogenados sólidos, na dose de $60 \mathrm{~kg}$ de N/ha aplicados logo após a irrigação e na diferenciação do primórdio floral, e dois fertilizantes liquidos com $5 \% \mathrm{~N}$ aplicado na dose de 8 litros/ha aos 45 dias da emergência, na diferenciação do primórdio floral e no florescimento do cultivar BR-IRGA 412, observou que as aplicações de nitrogênio favoreceram a produção de grãos, a estatura das plantas e o número de panículas $/ \mathrm{m}^{2}$, não havendo diferenças entre os produtos aplicados, para estas variáveis.

Lopes et al. (1993), em trabalho para estudar a influência de 4 niveis de nitrogênio $(40,70,100$ e $130 \mathrm{~kg}$ de $\mathrm{N} / \mathrm{ha}$ ), aplicados em 3 épocas, sobre o cultivar BR IRGA 416, encontraram respostas positivas no rendimento de grãos, somente para niveis de $\mathrm{N}$.

Spanu \& Pruneddu (1997), estudando o efeito de 6 níveis de nitrogênio entre 0 e $250 \mathrm{~kg}$ de $\mathrm{N} / \mathrm{ha}$, aplicados em diferentes combinações, nas fases de semeadura, perfilhamento e emissão de panículas, em arroz irrigado por aspersão, obtiveram aumento de produção de grãos de 5,4 ton/ha sem nitrogênio, para 10,3 ton/ha para o nivel máximo de N. As maiores produções de grãos foram obtidas para niveis de nitrogênio acima de $150 \mathrm{~kg} / \mathrm{ha}$, aplicados nas três fases do ciclo do arroz. 


\subsection{Efeitos do $\mathrm{N}$ sobre a qualidade de grãos de arroz}

Bernal et al. (1985), em estudo para determinar o efeito dos métodos de plantio de sementes pré-germinadas e transplantio manual de mudas de arroz, e de dois niveis de nitrogênio ( 0 e $150 \mathrm{~kg}$ de N/ha) sobre o rendimento de grãos de 6 cultivares encontraram diferenças significativas para todos os fatores estudados. A produção de grãos mostrando-se fortemente influenciada pela adubação nitrogenada, sendo observadas diferenças significativas para número de panículas $/ \mathrm{m}^{2}$, número de grãos por panícula, comprimento da panícula e estatura das plantas, para níveis de nitrogênio, cultivares e métodos de plantio.

Também observou-se que o rendimento industrial apresentou diferenças altamente significativas para níveis de nitrogênio, com $60,2 \%$ de grãos inteiros para o nível de $150 \mathrm{~kg}$ de $\mathrm{N} / \mathrm{ha}$ e $57,8 \%$ sem aplicação de nitrogênio, não havendo diferenças para cultivares e para métodos de plantio.

Silva \& Brandão (1987), em trabalho realizado para avaliar algumas caracteristicas de grãos de seis cultivares de arroz irrigado, em função de niveis de nitrogênio, constataram que o $\mathrm{N}$ não teve efeito significativo sobre o comprimento, largura e relação comprimento x largura dos grãos, entretanto entre os genótipos foram encontradas diferenças significativas para essas caracteristicas. Sendo o rendimento em grãos inteiros no beneficiamento influenciado pelo nitrogênio apenas para os cultivares "De Abril" e IR 665, diminuindo com níveis crescentes de adubação nitrogenada, para o "De Abril" e com aumento para o cultivar IR 665. 


\subsection{Efeitos do $\mathrm{N}$ sobre a qualidade de sementes de arroz}

Costa (1978), em estudo da influência de 4 níveis de nitrogênio $(30,60,90$ e $120 \mathrm{~kg}$ de $\mathrm{N} / \mathrm{ha}$ ) aplicados em 4 épocas, sobre os cultivares E.E.A.-406 Formosa, IAC 12-9, Bluebelle e IRGA 408, constatou que níveis, épocas e interação níveis $\mathrm{x}$ épocas não exerceram influência significativa sobre a qualidade fisiológica das sementes, germinação e vigor, avaliado através do envelhecimento rápido e de velocidade de emergência.

\subsection{Eficiência e utilização do $\mathbf{N}$ pelas plantas de arroz}

Fageria \& Barbosa Filho (1982), utilizando niveis de 25 e $80 \mathrm{~kg}$ de $\mathrm{N} / \mathrm{ha}$, avaliaram 60 cultivares de arroz irrigado para maior eficiência de utilização de nitrogênio, através do parâmetro $\mathrm{EN}$ ( $\mathrm{kg}$ de grãos $/ \mathrm{kg} \mathrm{N}$ ). Encontraram diferenças que permitiram a separação dos cultivares em quatro grupos quanto a eficiência de utilização de nitrogênio: eficientes não responsivos, eficientes responsivos, não eficientes responsivos e não eficientes não responsivos, devendo ser eliminados os cultivares pertencentes ao $3 .^{\circ} \mathrm{e} 4 .^{\circ}$ grupo.

Furlani et al. (1986), avaliando cultivares e linhagens de arroz de sequeiro e irrigado quanto a eficiência na absorção e utilização de nitrogênio em solução nutritiva, aos 41 e 50 dias de idade, respectivamente, observaram que os materiais irrigados apresentaram maiores variações na produção de matéria seca da parte aérea e das raízes do que os materiais de sequeiro, entretanto, todos os materiais de arroz se mostraram eficientes na absorção de $\mathrm{N}$, encontrando-se pequena variação entre eles quanto ao conteúdo total de $\mathrm{N}$, que variou de $70 \mathrm{a} 100 \%$ do $\mathrm{N}$ adicionado à solução nutritiva. 
Quanto à utilização do $\mathrm{N}$, os materiais de sequeiro se mostraram mais eficientes (46 a $115 \mathrm{mg} \mathrm{MS} / \mathrm{mg} \mathrm{N}$ ) que os materiais de irrigado (26 a $84 \mathrm{mg} \mathrm{MS} / \mathrm{mg} \mathrm{N}$ ), e os cultivares irrigados IAC 1278 e IAC 4440 classificaram-se como ineficiente e mediamente eficiente, respectivamente.

Resultados obtidos por Sudjadi et al. (1987), revelam que a menor eficiência de utilização de $\mathrm{N}$ pelas plantas de arroz e a diminuição nos ganhos de produção de grãos, estão associados aos níveis crescentes de nitrogênio. Confirmam também que a alta porcentagem de grãos fanados está associada às elevadas concentrações de $\mathrm{N}$ na planta.

Fernandes et al. (1990), em experimento sob condições controladas de luminosidade e temperatura, estudou a absorção de assimilação de nitrogênio em dois cultivares de arroz usando-se $\mathrm{NO}_{3}{ }^{-}$ou $\mathrm{NH}_{4}{ }^{+}$em doses de 5, 20 e $150 \mathrm{ppm}$. Observou que os tratamentos com $\mathrm{NH}_{4}^{+}$afetaram negativamente o peso fresco das plantas. Plantas sob $\mathrm{NH}_{4}{ }^{+}$apresentaram niveis mais elevados de $\mathrm{N}$-amino livre na parte aérea que plantas sob $\mathrm{NO}_{3}{ }^{\circ}$. Os níveis de açúcares solúveis foram mais elevados nas plantas que receberam $\mathrm{NO}_{3}^{-}$que naquelas que receberam $\mathrm{NH}_{4}^{+}$. Observando-se correlações negativas entre peso fresco das plantas, e os teores de $\mathrm{N}$-amino e $\mathrm{NH}_{4}{ }^{+}$nos tecidos com queda exponencial do peso das plantas. Em circunstâncias de uso prolongado de fontes de $\mathrm{N}$ amoniacal, segundo o autor, exige um manejo que permita a compatibilização entre as disponibilidades de carbono e de nitrogênio nas plantas.

Silveira \& Machado (1990), estudando a mobilização de fotossintetizados no desenvolvimento de panículas dos cultivares de arroz irrigado IAC 4440 e IAC 120, observaram senescência mais precoce do primeiro cultivar ter sido diretamente relacionada às maiores taxas de acúmulo de proteínas e de amido nas fases iniciais do crescimento das panículas, devido elevada intensidade de síntese protéica durante a 
formação do embrião. $\mathrm{O}$ acúmulo de $\mathrm{N}$ na panícula mostrou-se contínuo, tendo sido mais intenso entre o $6 .^{\circ} \mathrm{e} 25 .^{\circ}$ dia após o florescimento no "IAC 4440 ", e entre o $13 .^{\circ} \mathrm{e}$ $35^{\circ}$ dia após o florescimento, no IAC 120.

Soares et al. (1994), em experimento conduzidos em casa de vegetação, com 5 cultivares de arroz de sequeiro, plantados em vasos, sob 4 niveis de nitrogênio, verificaram que ocorreu aumento no teor de nitrogênio da raiz, palha e grão, à medida que se aumentaram as doses de $\mathrm{N}$ e que a parte da planta que apresentou maior teor de $\mathrm{N}$ foi o grão, seguido pela palha e pela raiz. Em termos de $\mathrm{N}$ exportado pelos grãos os cultivares diferiram dentro de cada nível de $\mathrm{N}$, com um percentual de exportação de nitrogênio que variou de 40 a $60 \%$.

A medida que se aumentaram os niveis de $\mathrm{N}$, as quantidades de nitrogênio extraídas reduziram proporcionalmente, embora tenham aumentado em valores absolutos, logo, as plantas utilizam mais o nitrogênio do solo quando baixos níveis de $\mathrm{N}$ foram aplicados, indicando que nem sempre o uso de maiores quantidades devem ser preferidas, e concluindo-se que existe um ponto de equilibrio, no qual a quantidade ideal de $\mathrm{N}$ aplicado deve ser a que proporciona maior retorno econômico.

Lopes et al. (1996), estudando respostas de 2 cultivares e 2 linhagens promissoras de arroz irrigado com diferentes ciclos, sob 6 níveis de fertilização nitrogenada $(0,30,60,90,120$ e $150 \mathrm{~kg}$ de $\mathrm{N} / \mathrm{ha})$, constataram que todos os genótipos responderam positivamente, em produção de grãos, à aplicação de nitrogênio, encontrando-se diferentes valores de incremento na produção de grãos em casca para cada unidade de nitrogênio aplicado, que variaram de 23 a 14 para os genótipos estudados. Observaram também aumento significativos na estatura das plantas com o incremento dos níveis de nitrogênio, e o número de panículas $/ \mathrm{m}^{2}$ aumentou somente para o cultivar BR IRGA 416. 


\section{MATERIAL E MÉTODO}

\subsection{Local do experimento}

O experimento foi instalado em solo de várzea da Estação Experimental de Agronomia, do Instituto Agronômico, localizada no município de Pindamonhangaba, região leste do Estado de São Paulo, cujas coordenadas geográficas são $22^{\circ} 55^{\prime}$ de latitude Sul e $45^{\circ} 30^{\prime}$ de longitude Oeste, com altitude de $560 \mathrm{~m}$.

\subsubsection{Solo}

O solo utilizado foi identificado como Glei Pouco Húmico, de acordo com levantamento realizado pelo Pesquisador Científico Dr. Rinaldo de Oliveira Calheiros. ${ }^{1}$

As análises da fertilidade do solo foram realizadas pelo laboratório de análises do Centro de Solos e Recursos Agroambientais do Instituto Agronômico de Campinas e revelaram os seguintes resultados:

\begin{tabular}{cccccccc}
\hline $\mathbf{P}$ & $\mathbf{M O}$ & $\mathbf{p H}$ & $\mathbf{K}$ & $\mathbf{C a}$ & $\mathbf{M g}$ & $\mathbf{H}+\mathbf{A l}$ & $\mathbf{V}$ \\
\hline $\mathrm{mg} \mathrm{dm}^{-3}$ & $\%$ & & $\ldots$ & - mmol $_{\mathrm{c}} \mathrm{dm}^{-3}$ & & & \\
38 & 2,0 & 4,1 & 1,8 & 15 & 7,0 & 64 & 27 \\
\hline
\end{tabular}

\footnotetext{
${ }^{1}$ Informação Pessoal. Pesq. Científico do Centro de Ecofisiologia e Biofísica. Instituto Agronómico, Campinas - SP.
} 


\subsubsection{Clima}

O clima do município de Pindamonhangaba, segundo classificação climática internacional de Koeppen é do tipo CWA: clima tropical de altitude com temperatura média do mês mais quente superior a $22^{\circ} \mathrm{C}$, temperatura média do mês mais frio inferior a $18^{\circ} \mathrm{C}$, verão quente e úmido e inverno seco.

$\mathrm{Na}$ Tabela 1 são apresentadas normais climatológicas, colhidas no Posto Meteorológico da Estação Experimental de Agronomia de Pindamonhangaba, do Instituto Agronômico, referentes ao periodo de 1961 a 1990.

Tabela 1. Normais climatológicas do município de Pindamonhangaba, período de 30 anos.

\begin{tabular}{lccccc}
\hline \multirow{2}{*}{ Meses } & \multicolumn{2}{c}{ Temperaturas } & Precipitaçōes & VR Média & $\begin{array}{c}\text { Insolação } \\
\text { Médias diárias }\end{array}$ \\
\cline { 2 - 3 } & Máxima & Mínima & mm & $\%$ & horas \\
\hline Jan & 32,4 & 18,5 & 209,7 & 80,2 & 5,6 \\
Fev & 32,9 & 18,6 & 169,5 & 80,1 & 6,2 \\
Mar & 32,0 & 17,9 & 154,4 & 80,6 & 6,2 \\
Abr & 29,8 & 15,5 & 76,1 & 80,7 & 6,3 \\
Mai & 27,4 & 12,1 & 57,6 & 80,8 & 6,1 \\
Jun & 26,0 & 9,8 & 38,2 & 79,8 & 6,2 \\
Jul & 26,1 & 9,0 & 25,0 & 77,5 & 6,6 \\
Ago & 27,9 & 10,8 & 33,4 & 74,7 & 6,8 \\
Set & 28,6 & 13,4 & 62,8 & 74,4 & 5,9 \\
Out & 29,8 & 15,5 & 114,0 & 75,7 & 5,7 \\
Nov & 31,0 & 16,7 & 129,2 & 76,1 & 5,9 \\
Dez & 31,2 & 17,9 & 189,5 & 79,4 & 5,1 \\
\hline Média anual & $\mathbf{2 9 , 6}$ & $\mathbf{1 4 , 6}$ & $\mathbf{1 2 5 9 , 4}$ & $\mathbf{7 8 , 3}$ & $\mathbf{6 , 0}$ \\
\hline
\end{tabular}

Fonte: Centro de Ecofisiologia e Biofisica - IAC 


\subsection{Tratamentos}

\subsubsection{Cultivares (Fator $\mathbf{A})$}

A escolha dos cultivares IAC 101, IAC 102 e IAC 242, dentre os demais recomendados para plantio em condições de várzea irrigada no Estado de São Paulo, baseou-se em resultados de produção de qualidade industrial e culinária dos grãos obtidos em ensaios regionais de competição de arroz irrigado instalados pelo IAC.

As sementes pertencentes à classe genética foram obtidas na Estação Experimental de Agronomia de Pindamonhangaba, do Instituto Agronômico de Campinas, e tiveram origem a partir de campos de multiplicação instalados pelo sistema de panícula por linha, fator fundamental para manutenção da pureza varietal em arroz.

As avaliações de germinação das amostras de sementes dos cultivares estudados foram realizadas no Núcleo de Produção de Sementes de Taubaté, da Coordenadoria de Assistência Técnica Integral (CATI), de acordo com as regras para análise de sementes (Brasil, 1992), cujo resultados obtidos foram: 84, 82 e 79\% para os cultivares IAC 102, IAC 101 e IAC 242, respectivamente.

\subsubsection{IAC-101}

É a denominação comercial da linhagem CNA 5721, introduzida do Centro Internacional de Agricultura Tropical (CIAT) da Colômbia, pelo Centro Nacional de Arroz e Feijão (CNPAF/EMBRAPA), e corresponde à linhagem P3293-F - 27-1P-1M-1B, originária do cruzamento 5738/3224/Costa Rica. Avaliada pelo Instituto Agronômico desde 1986, foi lançada em 1991 (Bastos et al., 1991). 
Suas principais características são descritas abaixo:

Rendimento de grãos:

$6302 \mathrm{~kg} / \mathrm{ha}$ (média de 23 ensaios)

\section{Características da planta:}

\begin{tabular}{|c|c|}
\hline Altura da planta ....... & $\ldots 89 \mathrm{~cm}$ \\
\hline Ciclo de maturação. & $\ldots 145$ dias \\
\hline 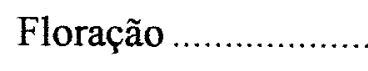 & $\ldots 114$ dias \\
\hline Acamamento ............ & ... resistente \\
\hline Arista & .... ausente \\
\hline 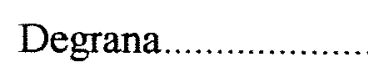 & ... moderada \\
\hline Cor das glumelas ..... & .... amarelo-palha \\
\hline Cor do apículo ........ & .... amarelo-claro \\
\hline Folhas........................ & .... eretas e pubescentes \\
\hline Glumelas .......................... & .... pubescentes \\
\hline Reação à brusone na & .... moderadamente suscetível \\
\hline Reaçãc & .... resistente \\
\hline
\end{tabular}

\section{Características de grãos:}

Tipo de grão .............................................. longo fino

Peso de 100 grãos (com casca) ................... 3,4 g

Comprimento ……................................ 7,92 mm

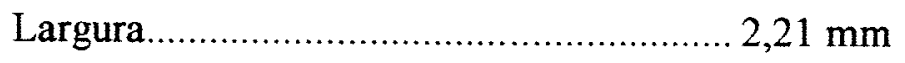

Espessura ............................................ 1,83 mm

Relação comprimento/largura ..................... 3,58

Rendimento no beneficiamento .................58,3\% 


\subsubsection{IAC-102}

Cultivar de ciclo intermediário, é o nome comercial da linhagem 1085, proveniente do cruzamento $P_{2} S_{1} 37-38 / L A C ~ 899$, realizado no Núcleo Experimental de Campinas, em 1984 e lançado em 1993 (Bastos et al., 1993).

\section{Rendimento de grãos:}

$6367 \mathrm{~kg} / \mathrm{ha}$ (média de 27 ensaios)

\section{Características da planta:}

Altura da planta $96 \mathrm{~cm}$

Ciclo de maturação 125 dias

Floração 92 dias

Acamamento mediamente resistente

Arista. grão múltico ou microaristado

Degrana moderada

Cor das glumelas amarelo-palha

Cor do apículo claro

Glumelas pubescentes

Folhas eretas e pubescentes

Comprimento da panícula $25 \mathrm{~cm}$

Número de grãos por panícula 135

Reação à brusone na panícula resistente

Reação à brusone na folha moderadamente suscetivel 


\section{Características de grãos:}

Tipo de grão longo fino

Peso de 100 grãos (com casca) $3,25 \mathrm{~g}$

Comprimento $7,98 \mathrm{~mm}$

Largura $2,10 \mathrm{~mm}$

Espessura $1,86 \mathrm{~mm}$

Relação comprimento/largura. 3,8

Rendimento de grãos inteiros $54,7 \%$ no beneficiamento

\subsubsection{IAC-242}

Descendente da linha P 3299- $\mathrm{F}_{4}^{-} 33-2$, obtida em 1984 pelo Instituto Agronômico, e melhorada a partir de população segregante introduzida no Centro Internacional de Agricultura Tropical (CIAT) da Colômbia, com base no cruzamento 5685/3250/IRAT 8, foi lançada em 1988 (Schmidt et al., s.d.).

\section{Rendimento de grãos:}

$6190 \mathrm{~kg} / \mathrm{ha}$ (média de 13 ensaios)

\section{Características da planta:}
Altura da planta
$105 \mathrm{~cm}$
Ciclo de maturação
140 dias
Floração 110 dias
Acamamento resistente
Arista. grão múltico ou microaristado 
Degrana ................................................ moderada

Cor das glumelas amarelo-palha

Cor do apículo claro

Glumelas pubescentes

Folhas eretas e pubescentes

Comprimento da panícula. $25 \mathrm{~cm}$

Número de grãos por panícula 152

Reação à brusone na panícula. resistente

Reação à brusone na folha resistente

\section{Características de grãos:}

Tipo de grão longo fino

Peso de 100 grãos (com casca) $3,4 \mathrm{~g}$

Comprimento $7,25 \mathrm{~mm}$

Largura $2,40 \mathrm{~mm}$

Espessura $1,85 \mathrm{~mm}$

Relação comprimento/largura 3,58

Rendimento em beneficiamento $57,9 \%$

\subsubsection{Níveis de nitrogênio (Fator B)}

$\mathrm{N}_{0}-0 \mathrm{~kg} \mathrm{~N} / \mathrm{ha}$

$\mathrm{N}_{1}-50 \mathrm{~kg} \mathrm{~N} / \mathrm{ha}$

$\mathrm{N}_{2}-100 \mathrm{~kg} \mathrm{~N} / \mathrm{ha}$

$\mathrm{N}_{3}-150 \mathrm{~kg} \mathrm{~N} / \mathrm{ha}$ 
As doses do fertilizante nitrogenado, correspondentes aos niveis de nitrogênio adotados, foram aplicadas em três frações de pesos iguais, sendo o fertilizante distribuído manualmente à lanço. A primeira fração foi aplicada 14 dias após a emergência das plantas, 4 dias após a inundação permanente das parcelas; a segunda fração foi aplicada no início do estádio de desenvolvimento dos perfilhos, 39 dias após a emergência das plantas, e a terceira fração no estádio de diferenciação do primórdio floral, de acordo com os ciclos dos cultivares, correspondendo a 67,63 e 67 dias após a emergência das plantas, para os cultivares IAC 101, IAC 102 e IAC 242, respectivamente.

\subsubsection{Fonte de nitrogênio}

O fertilizante utilizado como fonte de nitrogênio foi a uréia comercial perolada, que contém $45 \%$ de nitrogênio. Esta apresenta menor custo por unidade de nitrogênio, não produz resíduos ácidos e é de fácil manuseio, sendo obtida pela reação: $\mathrm{NH}_{3}+\mathrm{CO}_{2} \rightarrow(\mathrm{CONH})_{2}$

\subsection{Delineamento Experimental}

Para estudo dos efeitos dos niveis de fertilização nitrogenada sobre os cultivares de arroz irrigado adotou-se o esquema fatorial ( 4 níveis de $\mathrm{N} \times 3$ cultivares), com 12 tratamentos em blocos ao acaso em 3 repetições.

Das combinações possiveis entre os 3 cultivares e 4 niveis de nitrogênio resultaram os seguintes tratamentos:
1. $\mathrm{C}_{1} \mathrm{~N}_{0}$
4. $\mathrm{C}_{1} \mathrm{~N}_{1}$
7. $\mathrm{C}_{1} \mathrm{~N}_{2}$
10. $\mathrm{C}_{1} \mathrm{~N}_{3}$
2. $\mathrm{C}_{2} \mathrm{~N}_{0}$
5. $\mathrm{C}_{2} \mathrm{~N}_{1}$
8. $\mathrm{C}_{2} \mathrm{~N}_{2}$
11. $\mathrm{C}_{2} \mathrm{~N}_{3}$
3. $\mathrm{C}_{3} \mathrm{~N}_{0}$
6. $\mathrm{C}_{3} \mathrm{~N}_{1}$
9. $\mathrm{C}_{3} \mathrm{~N}_{2}$
12. $\mathrm{C}_{3} \mathrm{~N}_{3}$ 
As parcelas apresentaram 4 metros de largura e 5 metros de comprimento, com área total de $20 \mathrm{~m}^{2}$, sendo considerado como área útil $10 \mathrm{~m}^{2}(2,5 \times 4,0 \mathrm{~m})$.

As parcelas foram isoladas por taipas de terra, compactada para impedir a circulação da água entre as mesmas. Construiu-se condutores de água de irrigação e canais de drenagem para garantir o manejo independente da água entre as parcelas, conforme plano de campo (Figura 1).

\subsection{Instalação e condução do experimento}

\subsubsection{Preparo do solo}

O preparo do solo foi realizado com emprego de ferramentas manuais, com o objetivo de preservar a estrutura dos camalhões que separavam as parcelas, bem como os condutores de água de irrigação e os canais de drenagem.

Inicialmente o solo de cada parcela foi resolvido com auxílio de enxadões e destorroado com enxadas, simulando as operações de aração e gradagem, respectivamente, que compõem o preparo convencional do solo.

Com o solo previamente preparado, as parcelas foram inundadas, sendo solo e água misturados, empregando-se rastelos e enxadas para promover a formação do "barro".

As irregularidades na superficie do solo barrento foram corrigidas pela operação de aplainamento, realizada com a utilização de enxadas de tamanho grande, mas sempre tendo-se uma lâmina de água de $4-5 \mathrm{~cm}$ como referência de nível.

Concluído o preparo, e observando-se o efeito idêntico ao obtido pela utilização de máquinas, em lavouras comerciais de arroz pré-germinado, a espessura da lâmina de água foi ampliada para $10 \mathrm{~cm}$ e as parcelas consideradas prontas para as próximas operações. 
.24 .

PLANO DE CAMPO

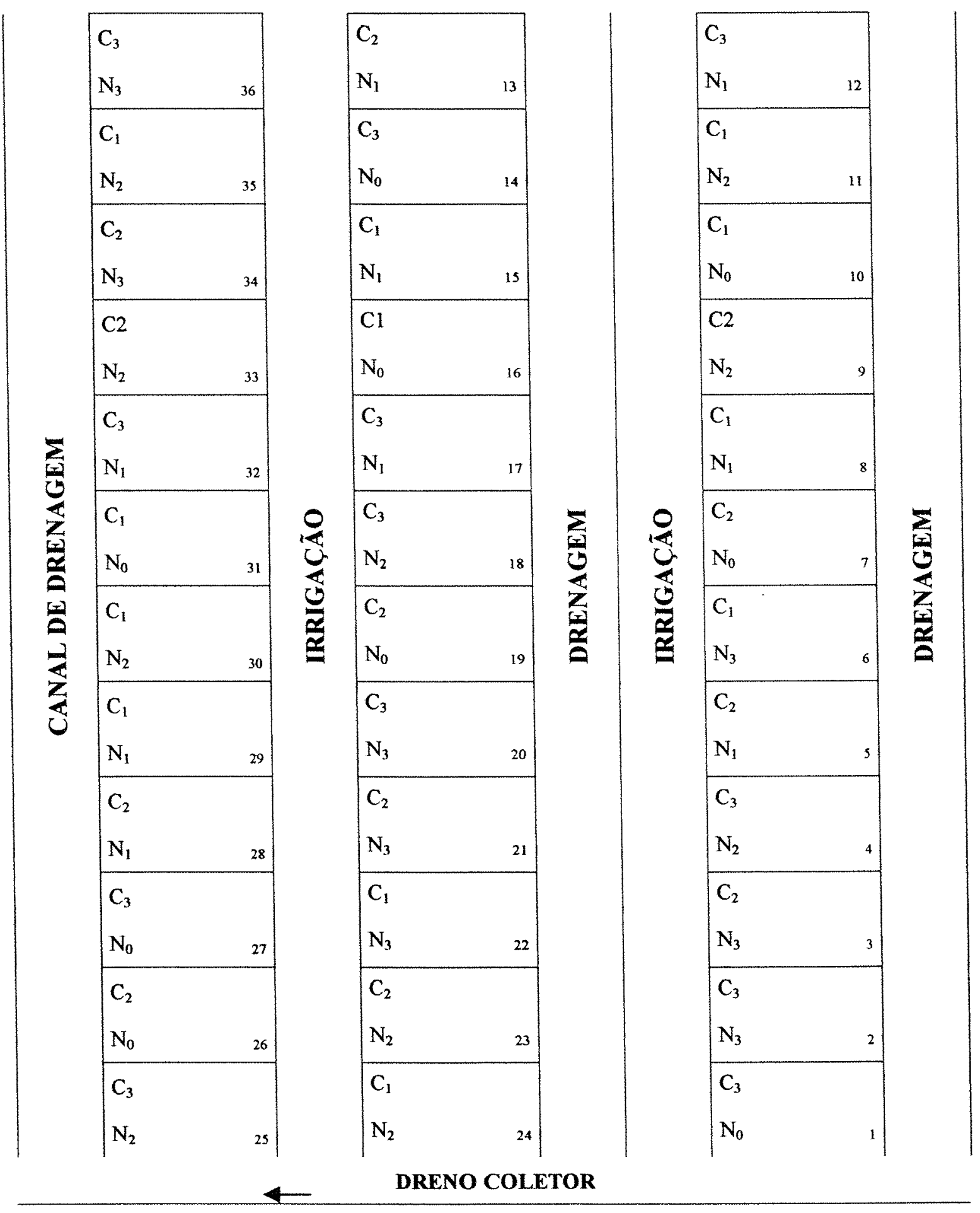

Figura 1. Plano de campo. 


\subsubsection{Adubação de plantio}

Constou da aplicação de $60 \mathrm{~kg}$ de $\mathrm{P}_{2} \mathrm{O}_{5} / \mathrm{ha}$ e $80 \mathrm{~kg}$ de $\mathrm{K}_{2} \mathrm{O} / \mathrm{ha}$, nas formas de superfosfato triplo e cloreto de potássio, respectivamente. A aplicação foi efetuada aos 14 dias após a emergência do arroz, juntamente com o primeiro terço da adubação nitrogenada.

\subsubsection{Controle de plantas daninhas}

As plantas daninhas de maior ocorrência na ocasião da instalação do experimento eram Echinochloa crusgalli e Ischaemum rugosum, controladas através do emprego conjunto de herbicida, manejo de água de irrigação e roguing.

Utilizou-se o herbicida Oxadiazon na dose de 2,5 litros/ha, aplicado em benzedura, sobre a lâmina de água 8 dias sem circulação de água, apenas com reposição. Um dia antes da semeadura, conforme recomendação do fabricante do herbicida foi feita a drenagem da água, para evitar efeitos fitotóxicos do produto sobre as sementes pré-germinadas de arroz.

Além da aplicação do herbicida a própria lâmina de água medida a $8 \mathrm{~cm}$ de espessura consistiu como um eficiente método de controle de plantas daninhas, devido, principalmente ao reduzido nível de oxigênio e acúmulo de dióxido de carbono produzido pela decomposição anaeróbica da matéria orgânica, que inibem a germinação das sementes das mesmas.

Também foi efetuada a eliminação manual, sempre que necessário, das plantas daninhas não controladas pelo herbicida e pela lâmina de água, evidenciando-se as plantas daninhas de multiplicação vegetativa, e algumas espécies aquáticas, além de misturas varietais de arroz oriundas de plantios anteriores todas com baixos niveis de infestação. 
O emprego conjunto desses três métodos de controle garantiu a eliminação praticamente total das plantas daninhas, presentes na área do ensaio não permitindo sua influência sobre os resultados obtidos no experimento.

\subsubsection{Semeadura}

A semeadura manual e a lanço de sementes pré-germinadas sobre o "barro" ocorrida em 8 de dezembro de 1996, logo após a retirada da lâmina d'água das parcelas (drenagem superficial) garantiu boa emergência e enraizamento das plantas de arroz. Adotou-se a densidade de 550 sementes por metro quadrado, sendo que aos 5 dias após a semeadura, a emergência das plântulas havia sido completa para os três cultivares .

A pré-germinação das sementes é o processo mediante o qual as sementes de arroz são hidratadas e logo ao serem postas em condições favoráveis de ambiente, a radícula e o coleoptilo iniciam seu desenvolvimento Centro Internacional de Agricultura Tropical - CIAT (1978).

Para hidratação, as sementes correspondentes a cada parcela experimental, foram embaladas em pequenos sacos de pano e deixadas por 24 horas no interior de um recipiente com água. Após esse periodo, as sementes foram incubadas por 36 horas em local sombreado, tomando-se os cuidados para mantê-las sempre úmidas, sendo consideradas apropriadas para semeadura quando a radícula e o coleoptilo apresentavam aproximadamente $2 \mathrm{~mm}$ de comprimento. 


\subsubsection{Manejo de água}

Nos 15 dias que sucederam a semeadura o solo foi mantido saturado, sendo após esse periodo, reinundado gradativamente conforme o desenvolvimento das plantas de arroz, até a lâmina d'água atingir 6 a $8 \mathrm{~cm}$ de espessura, para ser retirada somente aos 20 dias que antecederam a colheita.

Essa prática de manejo da água de irrigação proporcionou bom desenvolvimento inicial das plântulas de arroz, com estande adequado, complementou o controle inicial das plantas daninhas obtido pelo uso do herbicida, bem como, colaborou para redução de perdas de nitrogênio por volatilização, que ocorrem em consequêencia das reações de nitrificação e denitrificação.

\subsubsection{Colheita e preparo de sementes}

A colheita das parcelas, ocorreu 33 dias após o florescimento, quando as plantas de arroz apresentavam-se completamente maduras.

Inicialmente procedeu-se a demarcação da área útil das parcelas $\left(2,5 \times 4,0 \mathrm{~m}=10,0 \mathrm{~m}^{2}\right)$ com estacas de madeira e arame, para conferir exatidão aos trabalhos.

Da área útil foram colhidas 4 subamostras ao acaso, usando-se um quadrado de madeira de $0,25 \mathrm{~m}^{2}(0,5 \times 0,5 \mathrm{~m})$ para determinação do número de panículas $/ \mathrm{m}^{2}$, comprimento de panícula, número e peso de grãos granados e fanados por panícula.

Os remanescentes, $9 \mathrm{~m}^{2}$ da área útil foram colhidos manualmente, cortando-se as plantas a $30-35 \mathrm{~cm}$ de altura do solo e colocadas no interior de sacos de polipropileno trançado. 
As plantas de arroz foram trilhadas em uma pequena máquina de acionamento elétrico projetada e construída pelo Centro de Mecanização Agrícola, do Instituto Agronômico, Campinas-SP. O equipamento, na sua parte superior é dotado de um cilindro batedor semelhante ao encontrado em colhedoras automotrizes e na porção inferior uma caixa metálica para receber os grãos de arroz contendo impurezas, que foram separadas por peneiramento e ventilação manuais, em peneiras de malha apropriada.

As sementes, no interior de sacos de polipropileno trançados e devidamente identificados, foram secas ao sol, em terreiro de concreto, até atingirem $13 \%$ de umidade, determinada em aparelho da marca Eaton modelo Dole 400, de leitura direta em disco com escala.

Após o preparo, pesagem em balança da marca Gehaka, modelo BG 2000 e homogenização, o material foi embalado em sacos de papel pardo tipo kraft de $10 \mathrm{e}$ $15 \mathrm{~kg}$, identificados com o número da parcela correspondente e armazenados em local seco e ventilado.

Desta forma garantiu-se a disponibilidade de arroz em casca para avaliações da qualidade de sementes e de grãos.

\subsubsection{Análises Estatísticas}

As análises estatísticas dos resultados seguiu o modelo experimental adotado, fatorial $\mathrm{A} \times \mathrm{B}$, delineado em blocos ao acaso, compostos de doze tratamentos $\mathrm{e}$ três repetições. 
Utilizou-se o teste de Tukey para comparar as médias dos tratamentos A (cultivares) e as médias dos mesmos dentro de cada nivel do fator $\mathrm{B}$, quando houve interação A x B. A análise de regressão polinomial foi aplicada para as médias dos tratamentos B (níveis de N). O estudo da equação de regressão polinomial para cada cultivar foi efetuado quando houve significância da interação A x B (cultivares $x$ niveis $\operatorname{de} N$ ).

Nos casos em que não se verificou significância estatística da interação $\mathrm{A} \times \mathrm{B}$ foram determinadas equações polinomiais, tomando-se a média dos três cultivares.

O esquema da análise da variância, com aplicação do Teste $F$ para os cultivares (fator qualitativo), niveis de nitrogênio (fator quantitativo) e interação cultivares x nitrogênio, para o experimento em questão, está descrito no Quadro 1 e o esquema da análise de regressão polinomial para níveis de nitrogênio com aplicações do Teste F, está descrito no Quadro 2.

Quadro 1. Esquema da análise da variância.

\begin{tabular}{lccccc}
\hline Causas de Variação & G.L. & S.Q. & Q.M. & Valor F & Prob.> F \\
\hline Blocos & 2 & & & \\
Variedade & 2 & & & \\
Nitrogênio & 3 & & \\
Variedades x Nitrogênio & 6 & & \\
Residuo & 22 & & \\
\hline Total & 35 & & \\
\hline
\end{tabular}


Quadro 2. Esquema da análise da regressão polinomial.

\begin{tabular}{lccccc}
\hline Causas da Variação & GL & S.Q. & Q.M. & Valor F & Prob. > F \\
\hline Regressão linear & 1 & & & \\
Regressão quadrática & 1 & & \\
Desvios de regressão & 1 & & \\
Residuo & 22 & & \\
\hline
\end{tabular}

Para garantir a homogeneidade de variâncias e consequentemente a validade do teste $\mathrm{F}$ e dos testes de comparações múltiplas, adotou-se as funções de transformação de dados: arco seno da raiz de $\mathrm{x} / 100$ e raiz de $(\mathrm{x}+0,5)$.

\subsection{Variáveis estudadas}

\subsubsection{Ciclo}

Foi considerado como ciclo o número de dias contados da emergência das plântulas até o florescimento. No período de emissão das panículas todas as parcelas foram inspecionadas para determinação da data do florescimento, isto é, do estádio de antese, em aproximadamente $50 \%$ das espiguetas.

\subsubsection{Estatura das plantas}

Medida desde a superficie do solo até o ápice da panícula mais alta, excluindo-se as aristas, tomada ao acaso de 10 plantas da área útil das parcelas, após completada a maturação ou estádio 9 no ciclo vegetativo (CIAT, 1983). Os dados são expressos em centímetros usando-se somente números inteiros. 


\subsubsection{Número de panículas $/ \mathrm{m}^{2}$}

Obtido pela soma dos resultados da contagem direta das 40 panículas colhidas em 4 subamostras de $0,25 \mathrm{~m}^{2}$ demarcadas na área útil das parcelas.

\subsubsection{Comprimento da panícula}

Medida tomada em centímetros, da base ou nó ciliar até o ápice da panícula. (CIAT, 1983), correspondendo a média de 40 medições por parcela, realizadas em grupos de 10 panículas tomadas ao acaso das 4 subamostras demarcadas na área útil das parcelas.

\subsubsection{Número de espiguetas por panícula}

Média do número de espiguetas das 40 panículas amostradas para avaliar o comprimento.

\subsubsection{Número de grãos granados por panícula}

Média do número de granadas, separadas e contadas manualmente, das 40 panículas utilizadas para avaliar o comprimento.

\subsubsection{Número de grãos fanados por panícula}

Média do número de espiguetas fanadas, separadas e contadas manualmente, das 40 panículas utilizadas para avaliar o comprimento.

\subsubsection{Peso de grãos por panícula}

Média dos pesos, em gramas, das espiguetas, das 40 panículas utilizadas para avaliar o comprimento. 


\subsubsection{Peso de grãos granados por panícula}

Média dos pesos, em gramas, das espiguetas granadas, separadas manualmente, das 40 panículas utilizadas para avaliar o comprimento.

\subsubsection{Peso de grãos fanados por panícula}

Média dos pesos, em gramas, das espiguetas fanadas, separadas manualmente, das 40 panículas utilizadas para avaliar o comprimento.

\subsubsection{Peso de 1000 grãos}

Média dos pesos, em gramas, de 4 lotes de mil grãos granados, contados manualmente, dos grupos de 10 panículas tomadas ao acaso das subamostras de $0,25 \mathrm{~m}^{2}$.

\subsubsection{Dimensões dos grãos}

Comprimento, largura e espessura, em milímetros, determinados em 100 grãos com casca por parcela, por meio de paquímetro, com leitura para duas casas decimais.

\subsubsection{Produção de grãos em casca}

Conversão, para quilos por hectare, dos resultados de pesagem das produções da área útil $\left(10 \mathrm{~m}^{2}\right)$ das parcelas.

\subsubsection{Rendimento de grãos no beneficiamento}

Obtido 50 dias após o armazenamento. As amostras de 100 gramas de arroz em casca, foram pesadas em balança eletrônica de precisão de duas casas decimais 
da marca Gehaka, modelo BG 2000, e beneficiadas em moinho de provas da marca Suzuki modelo MT-87. O tempo de permanência de cada amostra no órgão brunidor foi de 1 minuto, conforme especificação do fabricante, sendo a separação de grãos inteiros e grãos quebrados feita em cilindro "Trier" acoplado ao equipamento. Foram determinados o peso de grãos inteiros e de grãos quebrados no beneficiamento e a renda do beneficiamento que compreende a soma do peso de grãos inteiros e grãos quebrados.

\subsubsection{Produção de grãos inteiros beneficiados}

É o produto do peso de grãos inteiros beneficiados, em porcentagem, pela produção em quilos por hectare de grãos em casca, sendo os resultados expressos em quilos por hectare.

\subsubsection{Produção de grãos quebrados beneficiados}

É o produto do peso de grãos quebrados beneficiados, dado em porcentagem, pela produção em quilos por hectare de grãos em casca, sendo os resultados expressos em quilos por hectare.

\subsubsection{Germinação das Sementes}

As avaliações de germinação foram realizadas com 100 sementes e 4 repetições distribuidas em dois rolos com 50 sementes cada (Brasil, 1992). As sementes contidas em rolo de papel especial e mantidas em germinador a temperaturas alternadas de $20^{\circ} \mathrm{C}$ por 16 horas e $30^{\circ} \mathrm{C}$ por 8 horas. A primeira avaliação foi feita aos cinco dias e a segunda aos quatorze dias após a instalação do teste. 


\subsubsection{Vigor das sementes}

As determinações de vigor foram conduzidas também com 100 sementes e 4 repetições e consistiram no envelhecimento acelerado, de acordo com métodos e técnicas descritos por Delouche \& Baskin (1973) e Marcos Filho et al. (1987), utilizando caixas tipo gerbox, mantida em câmara especial a $42^{\circ} \mathrm{C}$ e $100 \%$ de umidade relativa por 168 horas, e posteriormente as sementes foram colocadas para germinar à semelhança a descrita em 3.5.17 (Wetzel, 1972 e Razera et al., 1986).

\subsubsection{Massa seca de 100 sementes}

As medições de massa seca de 100 sementes foram feitas utilizando-se 200 sementes por parcela, mantidas em estufa a $105^{\circ} \mathrm{C}$, sem circulação forçada de ar, por 24 horas (Brasil, 1992).

\subsubsection{Peso hectolítrico}

Foi determinado em balança hectolítrica especial, marca Marte, de um quarto de litro, utilizando-se para essa análise duas subamostras de $250 \mathrm{ml}$, retiradas da amostra média de cada parcela e enviada ao laboratório em recipiente hermético. As determinações, conforme as regras de análise de sementes (Brasil, 1992), foram realizadas simultaneamente para evitar efeito da variação de umidade sobre o peso hectolítrico. 


\section{RESULTADOS}

\subsection{Ciclo}

Através da análise da variância constata-se valores de F significativos para o fator A (cultivares) e altamente significativos para o fator B (niveis de nitrogênio). As médias dos ciclos, em dias, para os três cultivares, o coeficiente de variação e a diferença mínima significativa são encontradas no Quadro 3.

Verifica-se pelas médias de ciclo exibidas no quadro 3 , que os cultivares IAC 101 e IAC 242 foram iguais entre si e superiores ao IAC 102 pelo teste de Tukey $(\alpha=0,05)$

Os resultados revelam efeito de níveis de nitrogênio apenas para o cultivar IAC 242 com diminuição de ciclo para níveis crescentes de nitrogênio.

A análise de regressão polinomial para os níveis de nitrogênio revelou efeito linear significativo dado pela equação:

$$
Y=2,67522+0,0002556 x, \operatorname{com} r^{2}=0,98
$$

onde:

Y é a variável dependente (ciclo); e $\mathrm{x}$ é a variável independente (níveis de nitrogênio). 
Quadro 3. Dados médios de ciclo, em dias.

\begin{tabular}{ccccc}
\hline \multicolumn{5}{c}{ Cultivares } \\
\hline Niveis de N & IAC 101 & LAC 102 & IAC 242 & Médias \\
\hline $\mathrm{kg} / \mathrm{ha}$ & & $79 \mathrm{a}$ & $87 \mathrm{a}$ & 83 \\
0 & $84 \mathrm{a}$ & $79 \mathrm{a}$ & $84 \mathrm{~b}$ & 82 \\
50 & $84 \mathrm{a}$ & $79 \mathrm{a}$ & $84 \mathrm{~b}$ & 82 \\
100 & $84 \mathrm{a}$ & $79 \mathrm{a}$ & $85 \mathrm{~b}$ & 82 \\
150 & $84 \mathrm{a}$ & $79 \mathrm{a}$ & $85 \mathrm{a}$ & \\
\hline Médias & $84 \mathrm{a}$ & $79 \mathrm{~b}$ & & \\
\hline CV\% & 1,22 & & \\
\hline
\end{tabular}

D.M.S. (5\%) cultivar 1,04

D.M.S. ( $5 \%$ niveis de nitrogênio dentro de cultivares) 2,30

\subsection{Estatura das plantas}

A análise da variância para estatura revelou valores de $\mathrm{F}$ significativos para cultivares, níveis de nitrogênio e interação de cultivares x níveis de nitrogênio.

No Quadro 4 são apresentados as médias de estatura das plantas em metros, o coeficiente de variação e a diferença mínima significativa.

Observando-se no quadro 4 , as médias de estatura das plantas dos três cultivares, verifica-se que os cultivares IAC 102 e IAC 242 não diferiram entre si, porém superaram o cultivar IAC 101, pelo teste dá-se que os cultivares apresentaram aumento de estatura para niveis crescentes de nitrogênio, porém com comportamentos distintos.

A análise de regressão polinomial para níveis de nitrogênio revelou valor de F significativo para regressão quadrática, dado pela equação polinomial: 
$Y=0,647667+0,0024867-0,00000733 x^{2}$,

$\operatorname{com} r^{2}=1,0$

onde:

Y é a variável dependente (estatura das plantas), e

X é a variável independente (níveis de nitrogênio).

Quadro 4. Médias de estatura das plantas, em $\mathrm{cm}$, para 12 tratamentos.

\begin{tabular}{ccccc}
\hline \multicolumn{5}{c}{ Cultivares } \\
\hline Niveis de N & IAC 101 & IAC 102 & IAC 242 & Médias \\
\hline $\mathrm{kg} / \mathrm{ha}$ & & & $\mathrm{cm}$ & \\
\hline 0 & $63,3 \mathrm{a}$ & $65,0 \mathrm{a}$ & $66,0 \mathrm{a}$ & 65,0 \\
50 & $69,6 \mathrm{~b}$ & $83,3 \mathrm{a}$ & $73,0 \mathrm{~b}$ & 75,3 \\
100 & $72,0 \mathrm{~b}$ & $86,6 \mathrm{a}$ & $88,3 \mathrm{a}$ & 82,3 \\
150 & $80,0 \mathrm{~b}$ & $90,6 \mathrm{a}$ & $85,3 \mathrm{ab}$ & 85,5 \\
\hline Médias & $71,2 \mathrm{~b}$ & $81,3 \mathrm{a}$ & $78,1 \mathrm{a}$ & \\
\hline CV\% & 5,02 & & & \\
\hline
\end{tabular}

D.M.S. $(5 \%)$ cultivar 4,0

D.M.S. (5\%) cultivar dentro de niveis de nitrogênio 8,0

Em decorrência da significância apresentada pela interação cultivar $\mathbf{x}$ nitrogênio, foi realizada análise da regressão polinomial da estatura das plantas de arroz em relação aos níveis de nitrogênio, para os cultivares individualmente, sendo que para o cultivar IAC 101 obteve-se valor de F significativo para regressão linear conforme a equação polinomial:

$$
Y=0,632667+0,0010867 x, \text { com } r^{2}=0,96
$$


Para o cultivar IAC 102 a análise mostrou efeito de F significativo para regressão linear dada pela equação polinomial:

$$
Y=0,693667+0,0016067 x, \text { com }^{2}=0,96
$$

E a análise de regressão polinomial para o cultivar IAC 242 mostrou valor de F significativo para efeito quadrático dado pela equação polinomial:

$$
Y=0,646667+0,0029667 x-0,0000100 x^{2} \operatorname{com} r^{2}=0,89
$$

A Figura 2 mostra as curvas de resposta da estatura dos três cultivares IAC 101, IAC 102 e IAC 242 à níveis crescentes de nitrogênio.

Nota-se para o cultivar IAC 242 maior efeito quadrático entre os níveis 0 e $100 \mathrm{~kg} / \mathrm{ha}$, sendo mais acentuado entre 50 e $100 \mathrm{~kg}$ de $\mathrm{N} / \mathrm{ha}$ e com tendência de estabilidade da estatura para o nivel de $150 \mathrm{~kg}$ de N/ha.

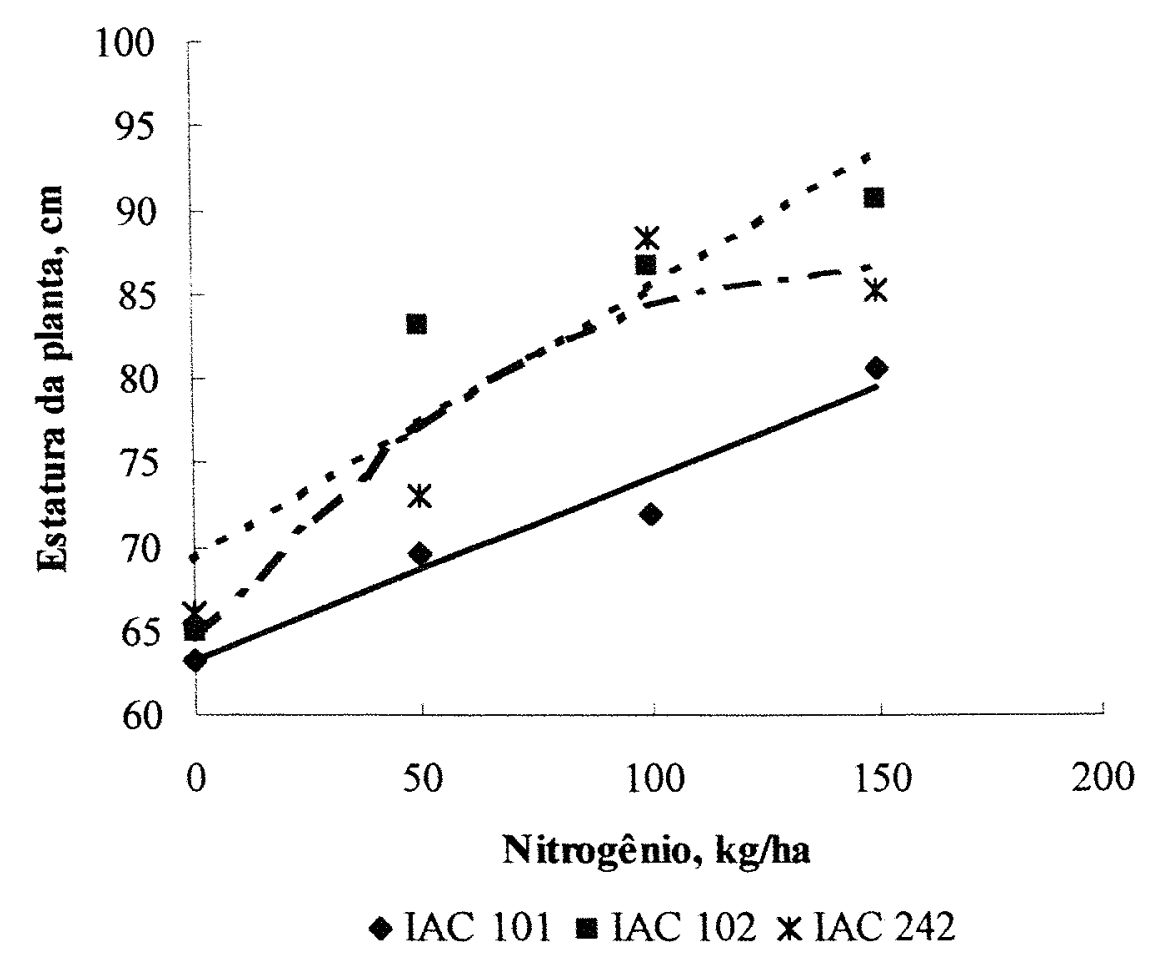

Figura 2. Curvas de resposta em estatura, dos cultivares estudados. 


\subsection{Número de panículas $/ \mathrm{m}^{2}$}

$\mathrm{Na}$ análise da variância foi encontrado valor de $\mathrm{F}$ significativo apenas para cultivares.

Os dados obtidos foram transformados, na análise estatística, em $\sqrt{ }(x+0,5)$, estando no Quadro 5 as médias originais, o coeficiente de variação e a diferença mínima significativa.

Quadro 5. Médias de número de panículas $/ \mathrm{m}^{2}$, para 12 tratamentos.

\begin{tabular}{ccccc}
\hline \multicolumn{5}{c}{ Cultivares } \\
\hline Níveis de N & IAC 101 & IAC 102 & IAC 242 & Médias (1) \\
\hline $\mathrm{kg} / \mathrm{ha}$ & & & & \\
0 & 634 & 661 & 793 & 696 \\
50 & 732 & 701 & 756 & 729 \\
100 & 686 & 650 & 824 & 720 \\
150 & 667 & 766 & 796 & 726 \\
\hline Médias (2) & $680 \mathrm{~b}$ & $694 \mathrm{~b}$ & $780 \mathrm{a}$ & \\
\hline CV\% & 11,52 & & & \\
\hline D.M.S. (5\%) & 84,94 & & & \\
\hline
\end{tabular}

O teste de Tukey $(\alpha=0,05)$ aplicado às médias de número de panículas $/ \mathrm{m}^{2}$ dos três cultivares permitiu constatar que o cultivar IAC 242 superou os demais que não diferiram entre si.

A análise da variância da regressão polinomial para níveis de nitrogênio não mostrou valores de $\mathrm{F}$ significativos para todas as causas de variação. 
.40 .

\subsection{Comprimento da panícula}

$\mathrm{Na}$ análise da variância encontrou-se valores de $\mathrm{F}$ significativos para cultivares e niveis de nitrogênio.

No Quadro 6 estão expostas as médias de comprimento da panícula, em centímetros, coeficiente de variação e diferença mínima significativa.

As médias comprimento de panícula apresentadas no quadro 6 mostram que o cultivar IAC 102 superou, os cultivares IAC 101 e IAC 242 que não diferiram entre si, pelo teste de Tukey $(\alpha=0,05)$.

Quadro 6. Médias de comprimento de panícula, em $\mathrm{cm}$, para 12 tratamentos.

\begin{tabular}{lcccc}
\hline \multicolumn{5}{c}{ Cultivares } \\
\hline Níveis de N & IAC 101 & IAC 102 & IAC 242 & Médias \\
\hline $\mathrm{kg} / \mathrm{ha}$ & & & $\mathrm{cm}$ & \\
0 & 16,33 & 17,66 & 16,33 & 16,77 \\
50 & 18,33 & 22,33 & 18,66 & 19,77 \\
100 & 18,66 & 24,00 & 20,66 & 21,11 \\
150 & 19,66 & 24,33 & 21,66 & 21,88 \\
\hline Médias & $18,25 \mathrm{~b}$ & $22,08 \mathrm{a}$ & $19,33 \mathrm{~b}$ & \\
\hline CV\% & 5,46 & & & \\
\hline D.M.S. (5\%) & 1,11 & & & \\
\hline
\end{tabular}

A análise de regressão polinomial para nível de nitrogênio revelou valor de F significativo para regressão quadrática, dado pela equação polinomial:

$$
Y=16,833333+0,0666667 x-0,00022222 x^{2}, \text { com }^{2}=0,99
$$

onde: 
Y é a variável dependente (comprimento de panícula); e

X é a variável independente (níveis de nitrogênio).

A Figura 3 exibe a curva de resposta do comprimento de panícula dos cultivares IAC 101, IAC 102 e IAC 242, submetidos à 4 níveis de nitrogênio.

Observa-se na figura 3 , maiores ganhos entre os niveis 0 e $50 \mathrm{~kg}$ de N/ha. A partir desse patamar os cultivares de arroz estudados apresentaram menores variações no comprimento de panícula.

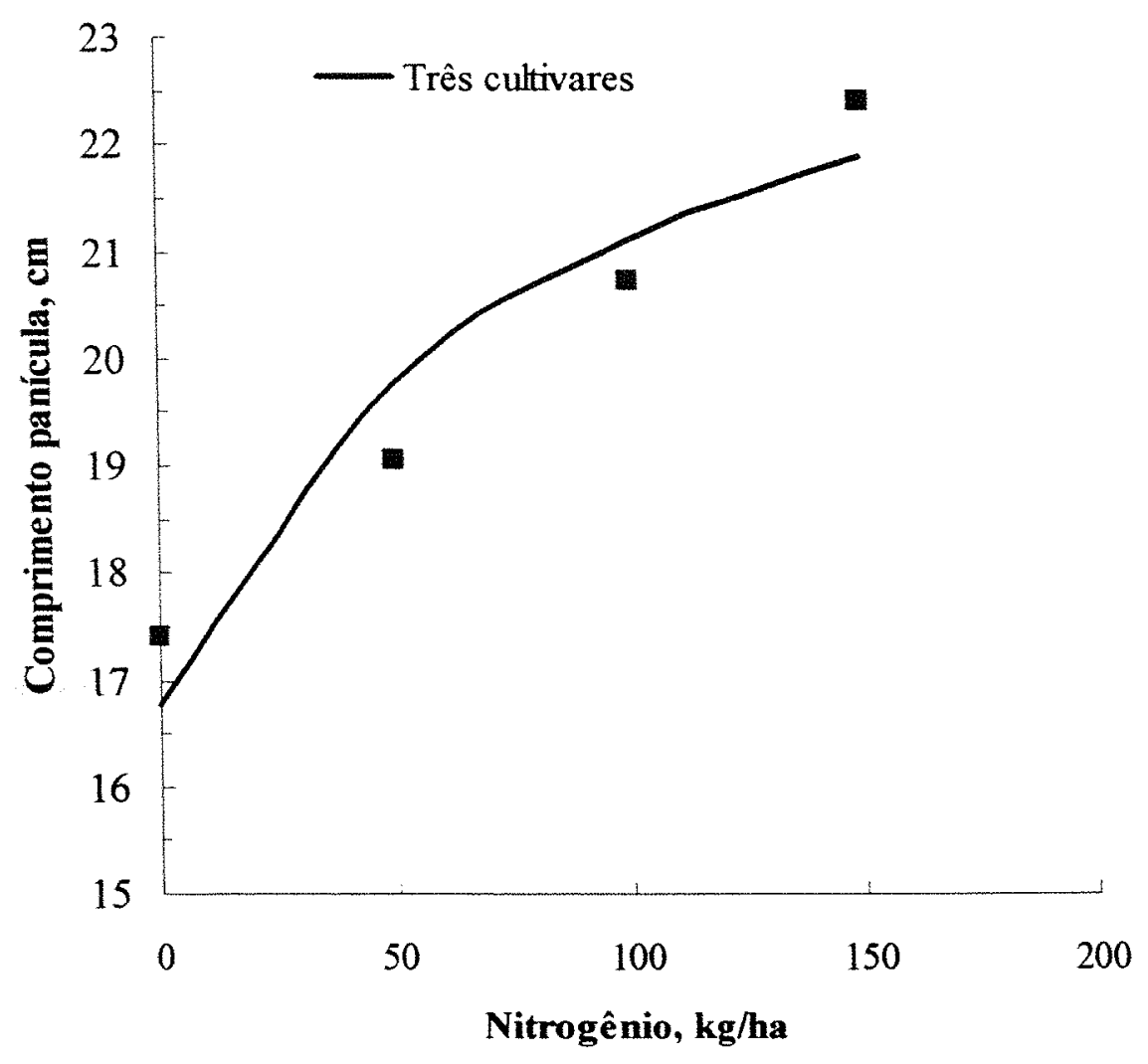

Figura 3. Curva de resposta do comprimento médio de panícula dos três cultivares de arroz irrigado aos quatro niveis de nitrogênio. 


\subsection{Número de espiguetas por panícula}

A análise da variância para o número de espiguetas por panícula acusou valores de F significativos para cultivares e níveis de nitrogênio.

$\mathrm{Na}$ análise estatística as observações foram transformadas em $\sqrt{ }(x+0,5)$, porém no Quadro 7 estão expostas as médias originais dos tratamentos, o coeficiente de variação e diferença minima significativa.

Quadro 7. Médias de número de espiguetas por panícula, para 12 tratamentos.

\begin{tabular}{lcccc}
\hline \multicolumn{5}{c}{ Cultivares } \\
\hline Níveis de N & IAC 101 & IAC 102 & IAC 242 & Médias \\
\hline kg/ha & 33,33 & 37,33 & 37,00 & 35,88 \\
0 & 45,00 & 70,33 & 50,66 & 55,33 \\
50 & 53,33 & 79,00 & 66,00 & 66,11 \\
100 & 66,00 & 85,00 & 76,66 & 75,88 \\
\hline 150 & $49,41 \mathrm{Bb}$ & $67,91 \mathrm{Aa}$ & $57,58 \mathrm{~b}$ & \\
\hline Médias & 14,82 & & & \\
\hline CV\% & 8,87 & & & \\
\hline
\end{tabular}

Examinando-se as médias de número de espiguetas por panícula dos três cultivares no quadro 7 , nota-se que o cultivar IAC 102 superou os demais, que não diferiram entre si pelo teste de Tukey $(\alpha=0,05)$.

As médias mostram aumento do número de espiguetas por panícula para niveis crescentes de nitrogênio, com maior variação para entre os níveis 0 e $50 \mathrm{~kg}$ de N/ha. 
$\mathrm{Na}$ análise da variância da regressão polinomial para niveis de nitrogênio, constatou-se valor de F significativo para regressão quadrática, conforme a equação polinomial:

$$
Y=36,272222+0,4065556 x-0,00096667 x^{2}, \text { com r }^{2}=0,99
$$

onde:

Y é a variável dependente (número de espiguetas por panícula): e X é a variável independente (níveis de nitrogênio).

As respostas dos cultivares IAC 101, IAC 102 e IAC 242 em número de espiguetas por panícula, para níveis de nitrogênio, podem ser observadas pela curva de resposta da figura 4.

A Figura 4 revela maior incremento do número de espiguetas por panícula entre os níveis 0 e $50 \mathrm{~kg}$ de $\mathrm{N} / \mathrm{ha}$, observando-se menor tendência para níveis acima de $100 \mathrm{~kg}$ de N/ha, mas que persiste até o nível de $150 \mathrm{~kg}$ de N/ha.

Derivando-se a equação de regressão polinomial (7) obteve-se o nível de $210 \mathrm{~kg}$ de N/ha como a de máxima resposta para número de espiguetas por panícula, que contribui para o número máximo de 79 espiguetas por panícula. 


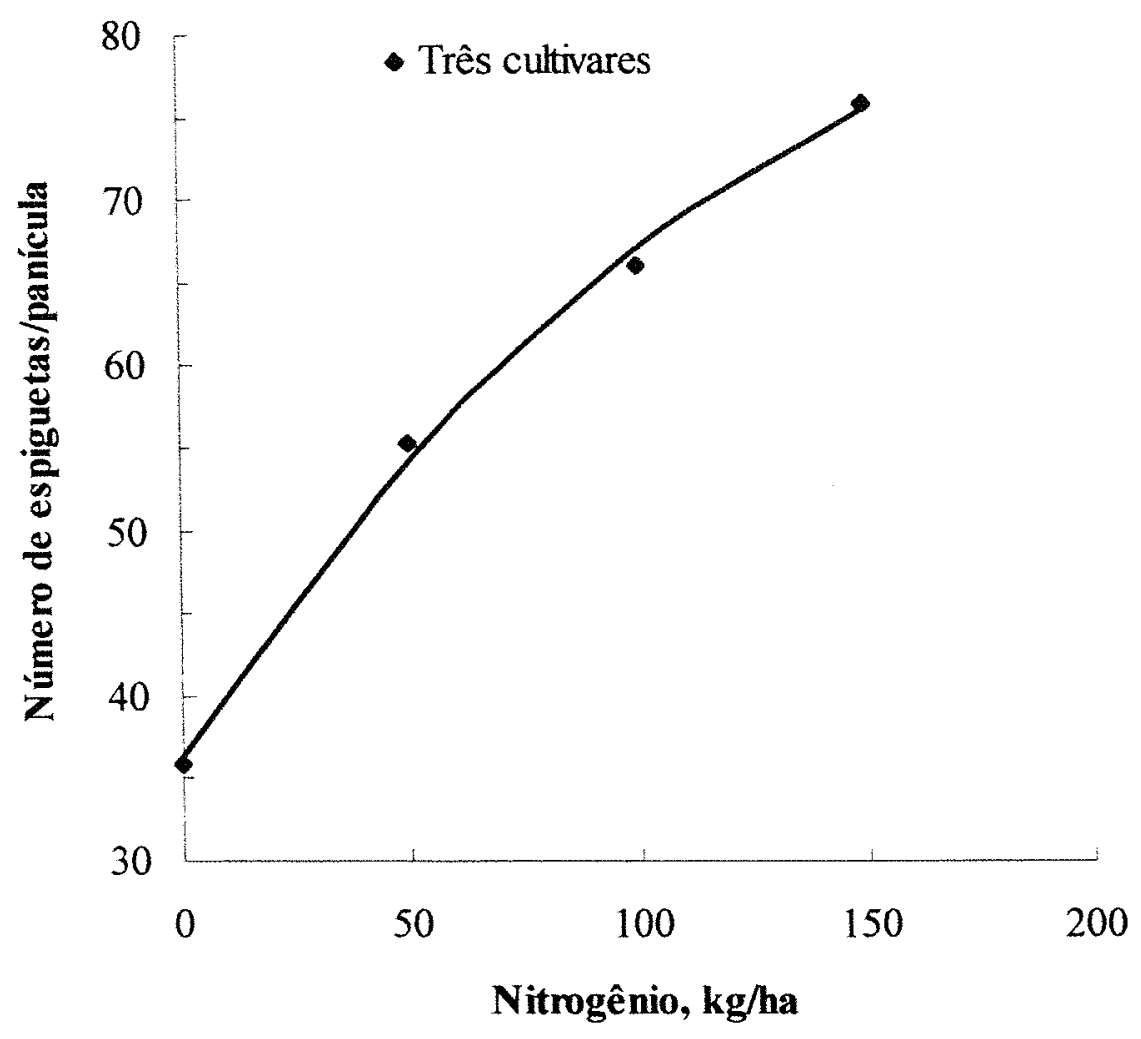

Figura 4. Curva de resposta do número de espiguetas por panícula dos três cultivares aos quatro níveis de nitrogênio. 


\subsection{Número de grãos granados por panícula}

$\mathrm{Na}$ análise da variância encontrou-se valores de $\mathrm{F}$ significativos para cultivares, nitrogênio e interação nitrogênio x cultivares.

$\mathrm{Na}$ análise estatística as observações foram transformadas em $\sqrt{ }(x+0,5)$ porém, no Quadro 8 são apresentadas as médias originais, o coeficiente de variação e a diferença mínima significativa.

Quadro 8. Médias de número de grãos granados por panícula para 12 tratamentos.

\begin{tabular}{lcccc}
\hline \multicolumn{5}{c}{ Cultivares } \\
\hline Niveis de N & IAC 101 & IAC 102 & IAC 242 & Médias (1) \\
\hline $\mathrm{kg} / \mathrm{ha}$ & & & & \\
0 & $27,33 \mathrm{a}$ & $31,66 \mathrm{a}$ & $26,33 \mathrm{a}$ & 28,44 \\
50 & $32,66 \mathrm{~b}$ & $56,00 \mathrm{a}$ & $34,66 \mathrm{~b}$ & 41,11 \\
100 & $36,33 \mathrm{~b}$ & $63,66 \mathrm{a}$ & $45,00 \mathrm{~b}$ & 48,33 \\
150 & $45,66 \mathrm{~b}$ & $68,66 \mathrm{a}$ & $48,33 \mathrm{~b}$ & 54,22 \\
\hline Médias (2) & $35,49 \mathrm{~b}$ & $54,99 \mathrm{a}$ & $38,58 \mathrm{~b}$ & \\
\hline CV\% & 12,56 & & \\
\hline D.M.S. (5\%) & 5,54 & & & \\
\hline D.M.S. (5\%) & Cultivares dentro de nitrogênio (11,09) & & \\
\hline
\end{tabular}

Verifica-se pelas médias dos três cultivares no quadro 8 , que o cultivar IAC 102 apresentou maior média de grãos granados por panícula, superando os demais cultivares, que não diferiram entre si, pelo teste de Tukey $(\alpha=0,05)$. 
Pelo teste de Tukey $(\alpha=0,05)$ aplicado às médias de número de grãos granados por panícula dos cultivares dentro de cada nivel do fator nitrogênio, verificou-se que para o nível zero os três cultivares não diferiram entre si. Para os demais níveis de nitrogênio o cultivar IAC 102 superou os cultivares IAC 101 e IAC 242 que não diferiram entre si.

A análise da variância da regressão polinomial para os níveis de nitrogênio, revelou valor de $F$ significativo para regressão quadrática, conforme a equação polinomial:

$$
Y=28,65+0,2707778 x-0,0006778 x^{2}
$$

Efeitos dos níveis de nitrogênio sobre a variável, número de grãos granados por panícula, para os cultivares IAC 101, IAC 102 e IAC 242 podem ser observados pela curva de resposta apresentada na Figura 5. 


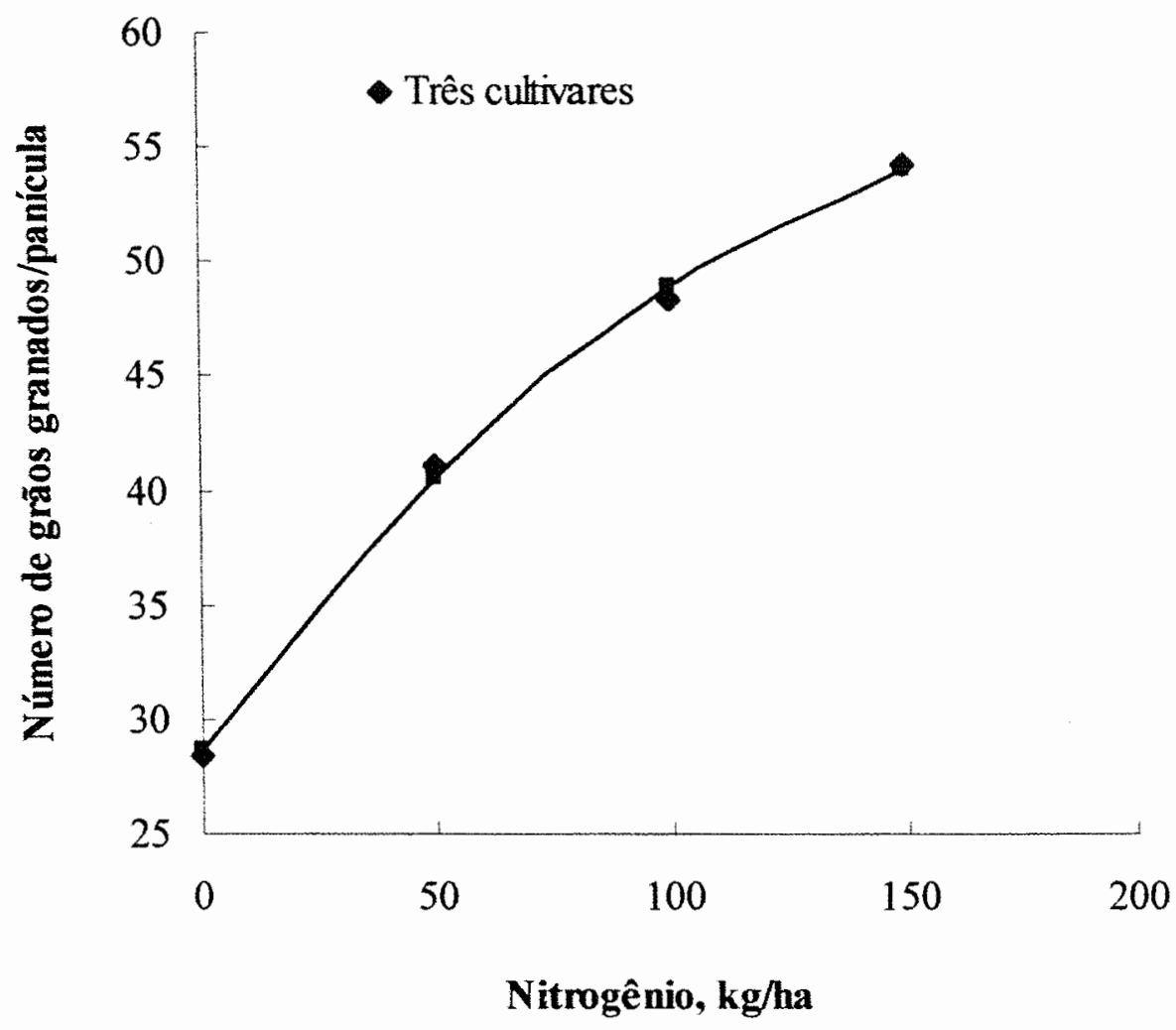

Figura 5. Curva de resposta do número de grãos granados por panícula de três cultivares de arroz irrigado à quatro níveis de nitrogênio. 


\subsection{Número de grãos fanados por panícula}

A análise da variância revelou valores de $\mathrm{F}$ significativos para cultivares e niveis de nitrogênio.

$\mathrm{Na}$ análise estatística as observações foram transformadas em $\sqrt{ }(\mathrm{x}+0,5)$, estando no Quadro 9 as médias originais dos tratamentos o coeficiente de variação e a diferença mínima significativa.

Quadro 9. Médias de número de grãos fanados por panícula, para 12 tratamentos.

\begin{tabular}{lcccc}
\hline \multicolumn{5}{c}{ Cultivares } \\
\hline Níveis de $\mathbf{~}$ & IAC 101 & IAC 102 & IAC 242 & Médias (1) \\
\hline kg/ha & 5,66 & 4,00 & 10,00 & 6,55 \\
0 & 11,33 & 13,66 & 15,00 & 13,33 \\
50 & 16,00 & 14,66 & 20,00 & 16,88 \\
100 & 19,33 & 15,66 & 27,66 & 20,88 \\
150 & $13,08 \mathrm{~b}$ & $11,99 \mathrm{~b}$ & $18,16 \mathrm{a}$ & \\
\hline Médias (2) & 28,08 & & & \\
\hline CV\% & 4,15 & & & \\
\hline D.M.S. (5\%) & & & \\
\hline
\end{tabular}

Através do teste de Tukey $(\alpha=0,05)$ aplicado às médias de número de grãos fanados por panícula do quadro 9, constatou-se que o cultivar IAC 242 superou os demais cultivares, que não diferiram entre si.

A análise da variância da regressão polinomial para níveis de nitrogênio apresentou valor de F significativo para regressão linear, com efeito positivo conforme a equação polinomial: 
$Y=7,433333+0,0931111 \times \operatorname{com}^{2}=0,99$

onde:

Y é a variável dependente (número de grãos fanados p/panícula); e

$\mathrm{X}$ é a variável independente (níveis de nitrogênio).

Os efeitos dos níveis de nitrogênio sobre os cultivares IAC 101, IAC 102 e IAC 242, em número de grãos fanados por panícula, podem ser observados pela curva de resposta da Figura 6.

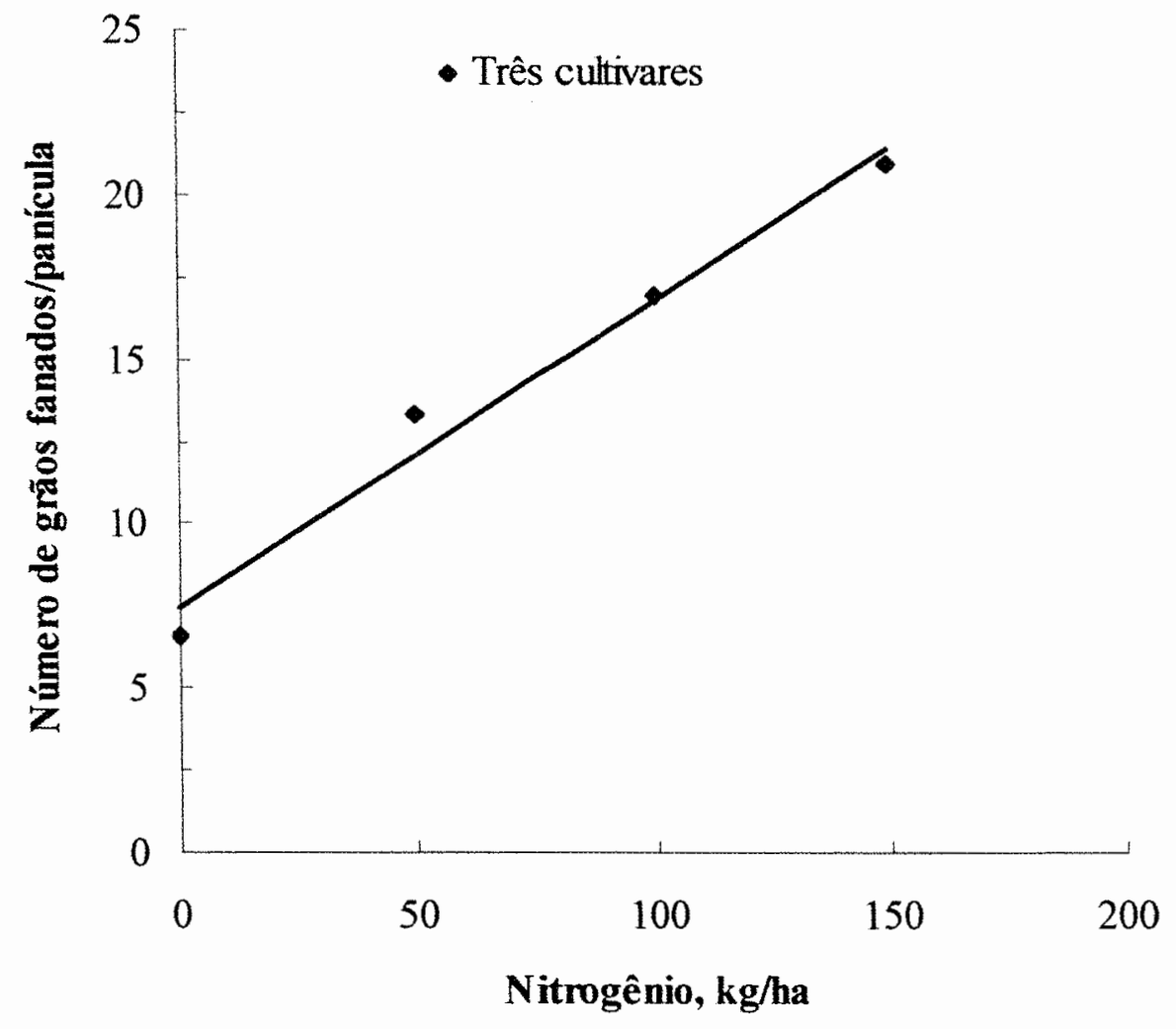

Figura 6. Curva de resposta de grãos fanados por panícula de três cultivares de arroz irrigado, submetidos a quatro niveis de fertilização nitrogenada. 


\subsection{Peso de grãos por panícula}

A análise da variância mostrou valores de $\mathrm{F}$ significativos para cultivares $\mathrm{e}$ níveis de nitrogênio.

O Quadro 10 apresenta as médias de peso em gramas de grãos por panícula, o coeficiente de variação e diferença mínima significativa.

Quadro 10. Médias de peso de grãos por panícula, para 12 tratamentos.

\begin{tabular}{lcccc}
\hline \multicolumn{5}{c}{ Cultivares } \\
\hline Niveis de N & IAC 101 & IAC 102 & IAC 242 & Médias (2) \\
\hline $\mathrm{kg} / \mathrm{ha}$ & 0,66 & 0,33 & 0,66 & 0,55 \\
0 & 1,00 & 1,33 & 1,00 & 1,11 \\
50 & 1,00 & 2,00 & 1,33 & 1,55 \\
100 & 1,33 & 2,00 & 1,33 & 1,55 \\
\hline 150 & $1,00 \mathrm{a}$ & $1,41 \mathrm{a}$ & $1,00 \mathrm{a}$ & \\
\hline Médias (1) & 37,18 & & & \\
\hline CV\% & 0,43 & & & \\
\hline D.M.S. (5\%) & & & \\
\hline
\end{tabular}

Verifica-se pelas médias apresentadas no quadro 10 que os três cultivares não diferiram significativamente entre si, pelo teste de Tukey $(\alpha=0,05)$, embora o cultivar IAC 102 tenha apresentado maior peso médio de grãos por panícula que os demais.

No nível zero de nitrogênio o cultivar IAC 102 que apresentou menor média, superou os cultivares IAC 101 e IAC 242. nos demais níveis. 
$\mathrm{Na}$ análise de regressão polinomial para níveis de nitrogênio foi encontrado valor de F significativo para regressão linear dado pela equação polinomial:

$$
\mathrm{Y}=0,655556+0,0064444 x, \text { com } \mathrm{r}^{2}=0,99
$$

onde:

Y é a variável dependente (peso de grãos por panícula); e

$\mathrm{X}$ é a variável independente (níveis de nitrogênio).

Na Figura 7 encontra-se a curva de resposta do peso de grãos por panícula, dos cultivares IAC 101, IAC 102 e IAC 242, submetidos a quatro niveis de adubação nitrogenada.

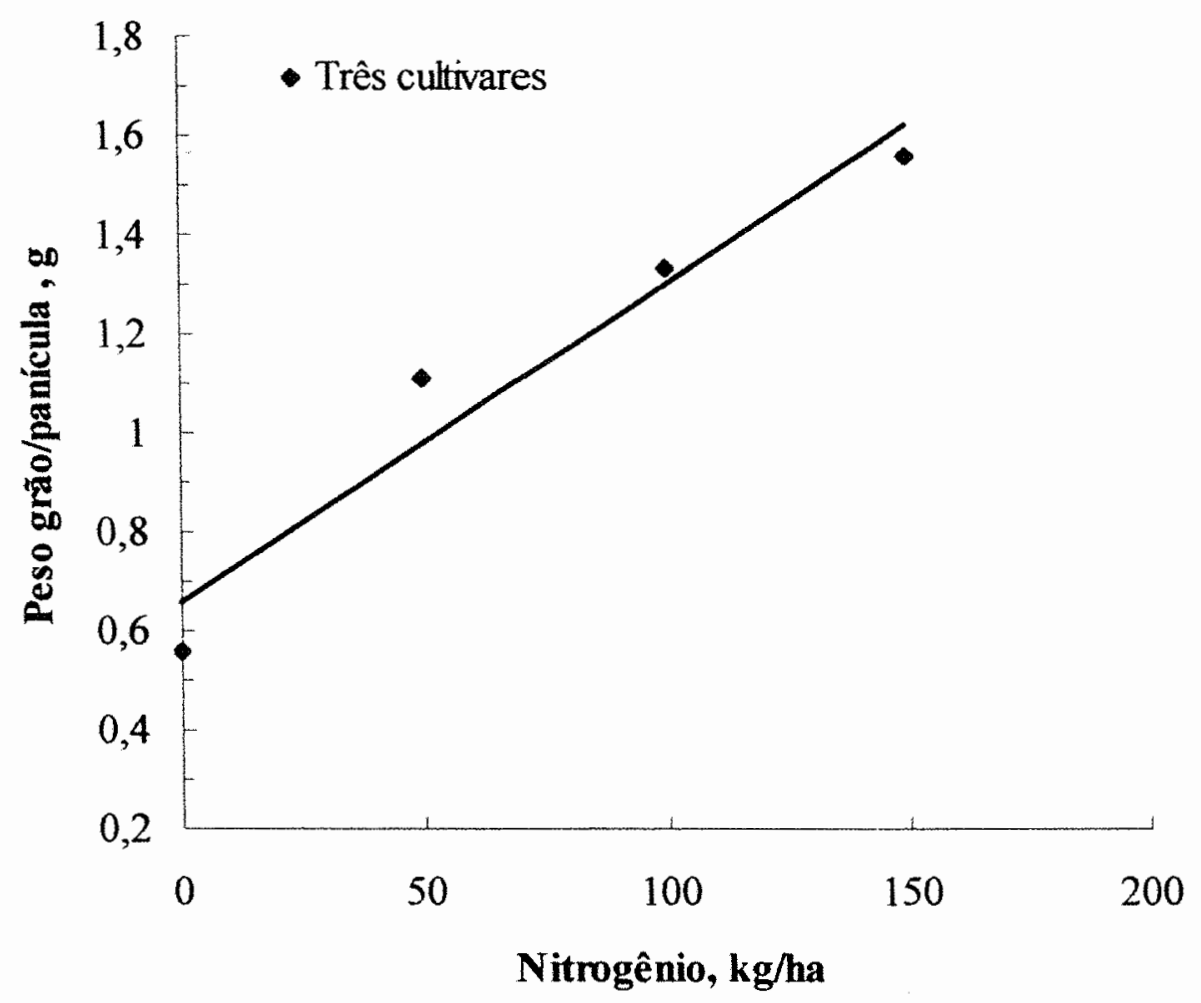

Figura 7. Curva de resposta do peso médio de grãos por panícula de três cultivares aos quatro niveis de nitrogênio. 


\subsection{Peso de grãos granados por panícula}

$\mathrm{Na}$ análise da variância foram encontrados valores de $\mathrm{F}$ significativos para cultivares, níveis de nitrogênio e interação cultivares x nitrogênio.

No Quadro 11 estão expostas as médias de três repetições de peso de grãos granados por panícula, em gramas, o coeficiente de variação e a diferença mínima significativa.

Quadro 11. Médias de peso de grãos granados por panícula, em gramas, para 12 tratamentos.

\begin{tabular}{lcccc}
\hline \multicolumn{5}{c}{ Cultivares } \\
\hline Niveis de N & IAC 101 & IAC 102 & IAC 242 & Médias (1) \\
\hline $\mathrm{kg} / \mathrm{ha}$ & & & $\mathrm{g}$ & \\
0 & $0,66 \mathrm{a}$ & $0,33 \mathrm{a}$ & $0,00 \mathrm{a}$ & 0,33 \\
50 & $1,00 \mathrm{a}$ & $1,00 \mathrm{a}$ & $0,66 \mathrm{a}$ & 0,89 \\
100 & $1,00 \mathrm{a}$ & $1,66 \mathrm{a}$ & $1,00 \mathrm{a}$ & 1,22 \\
150 & $1,00 \mathrm{~b}$ & $2,33 \mathrm{a}$ & $1,00 \mathrm{~b}$ & 1,44 \\
\hline Médias (2) & $0,91 \mathrm{~b}$ & $1,33 \mathrm{a}$ & $0,66 \mathrm{~b}$ & \\
\hline CV\% & 39,70 & & \\
\hline D.M.S. (5\%) (cult) & 0,40 & & \\
\hline D.M.S. (5\%) (cultivares dentro de nitrogênio) 0,79 & \\
\hline
\end{tabular}

A comparação das médias de peso de grãos granados por panícula dos três cultivares no quadro 11 pelo teste de Tukey $(\alpha=0,05)$ permitiu constatar, que o cultivar IAC 102 foi superior aos demais cultivares, que não diferiram entre si. 
O teste de Tukey $(\alpha=0,05)$ aplicado às médias de peso de grãos granados por panícula, dos cultivares dentro de cada nível do fator nitrogênio, revelou que apenas para $150 \mathrm{~kg}$ de $\mathrm{N} /$ ha houve diferença significativa para cultivares, com o IAC 102 superando os cultivares IAC 101 e IAC 242, que não diferiram entre si.

A análise da variância da regressão polinomial para os níveis de nitrogênio, mostrou valor de F significativo para regressão linear conforme equação polinomial:

$$
\mathrm{Y}=0,422222+0,0073333 \mathrm{x}, \mathrm{com} \mathrm{r}^{2}=1,00
$$

onde:

Y é a variável dependente (peso de grãos granados por panícula);

X é a variável independente (níveis de nitrogênio).

Tendo em vista a significância apresentada pela interação cultivar $\mathrm{x}$ nitrogênio foi feito estudo da análise de regressão polinomial do peso de grãos granados por panícula em relação aos niveis de nitrogênio, para os cultivares separadamente.

Para o cultivar IAC 102 obteve-se valor de F significativo para regressão linear conforme a equação polinomial:

$$
\mathrm{Y}=0,333333+0,0133333 x, \operatorname{com}^{2}=1,00
$$

Em relação ao IAC 242, verificou-se valor de F significativo para regressão quadrática conforme a equação polinomial:

$$
Y=0+0,0166667-0,00006667 x^{2}, \operatorname{com~}^{2}=1,0
$$

Os efeitos de niveis de nitrogênio sobre a variável, peso de grãos granados por panícula, para os cultivares IAC 102 e IAC 242 encontram-se representados pelas curvas de respostas da Figura 8. 


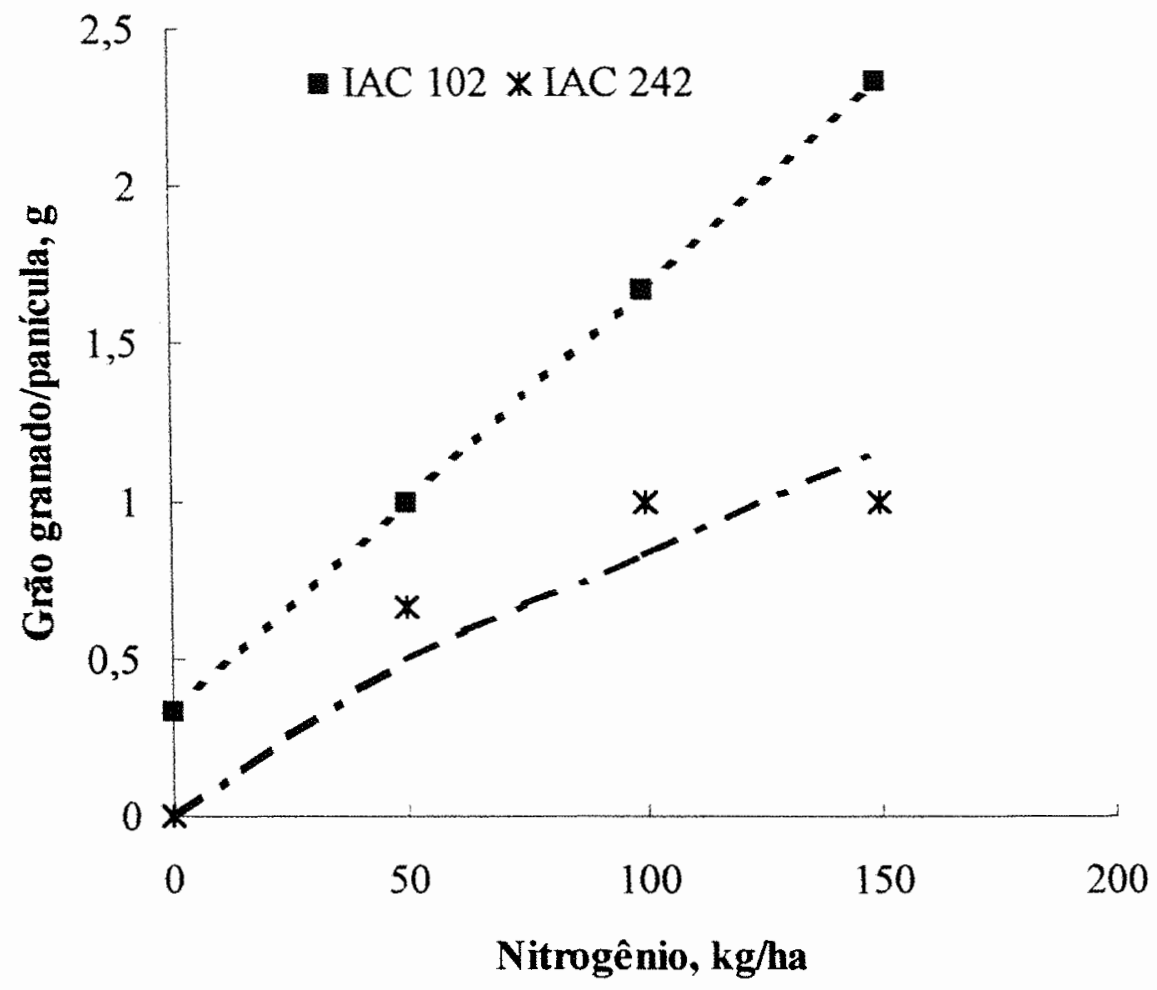

Figura 8. Curvas de resposta do peso de grãos granados por panícula dos cultivares IAC 102 e IAC 242. 


\subsection{Peso de grãos fanados por panícula}

A análise da variância para o peso de grãos fanados por panícula revelou valores de $\mathrm{F}$ significativos para cultivares e níveis de nitrogênio.

O Quadro 12 apresenta as médias de 3 repetições de grãos fanados por panícula, em gramas, o coeficiente de variação e a diferença mínima significativa.

Quadro 12. Médias de peso de grãos fanados por panícula, em gramas, para 12 tratamentos.

\begin{tabular}{lcccc}
\hline \multicolumn{5}{c}{ Cultivares } \\
\hline Niveis de N & IAC 101 & IAC 102 & IAC 242 & Médias (1) \\
\hline $\mathrm{kg} /$ ha & & 0,04 & 0,11 & 0,07 \\
0 & 0,06 & 0,12 & 0,13 & 0,13 \\
50 & 0,12 & 0,13 & 0,22 & 0,17 \\
100 & 0,17 & 0,15 & 0,28 & 0,21 \\
150 & 0,20 & $0,11 \mathrm{~b}$ & $0,20 \mathrm{a}$ & \\
\hline Médias (2) & $0,14 \mathrm{~b}$ & & & \\
\hline CV\% & 25,50 & & & \\
\hline
\end{tabular}

Constata-se pelas médias de peso de grãos fanados por panícula dos três cultivares no quadro 12, que o cultivar IAC 242 superou os cultivares IAC 101 e IAC 102, que não diferiram entre si, pelo teste de Tukey $(\alpha=0,05)$.

As médias mostram efeito positivo de níveis crescentes de nitrogênio sobre o peso de grãos fanados por panícula.

$\mathrm{Na}$ análise da variância da regressão polinomial para níveis de nitrogênio verifica-se valor de $\mathrm{F}$ significativo para regressão linear, conforme a equação polinomial: 
$\mathrm{Y}=0,081222+0,0009244 \mathrm{x}$, com $\mathrm{r}^{2}=0,99$

onde:

Y é a variável dependente (peso de grãos fanados por panícula); $\mathrm{e}$

$\mathrm{X}$ é a variável independente (níveis de nitrogênio).

Os efeitos dos níveis de nitrogênio sobre a variável, peso de grãos fanados por panícula, para os cultivares IAC 101, IAC 102 e IAC 242 podem ser observados pela curva de resposta da Figura 9.

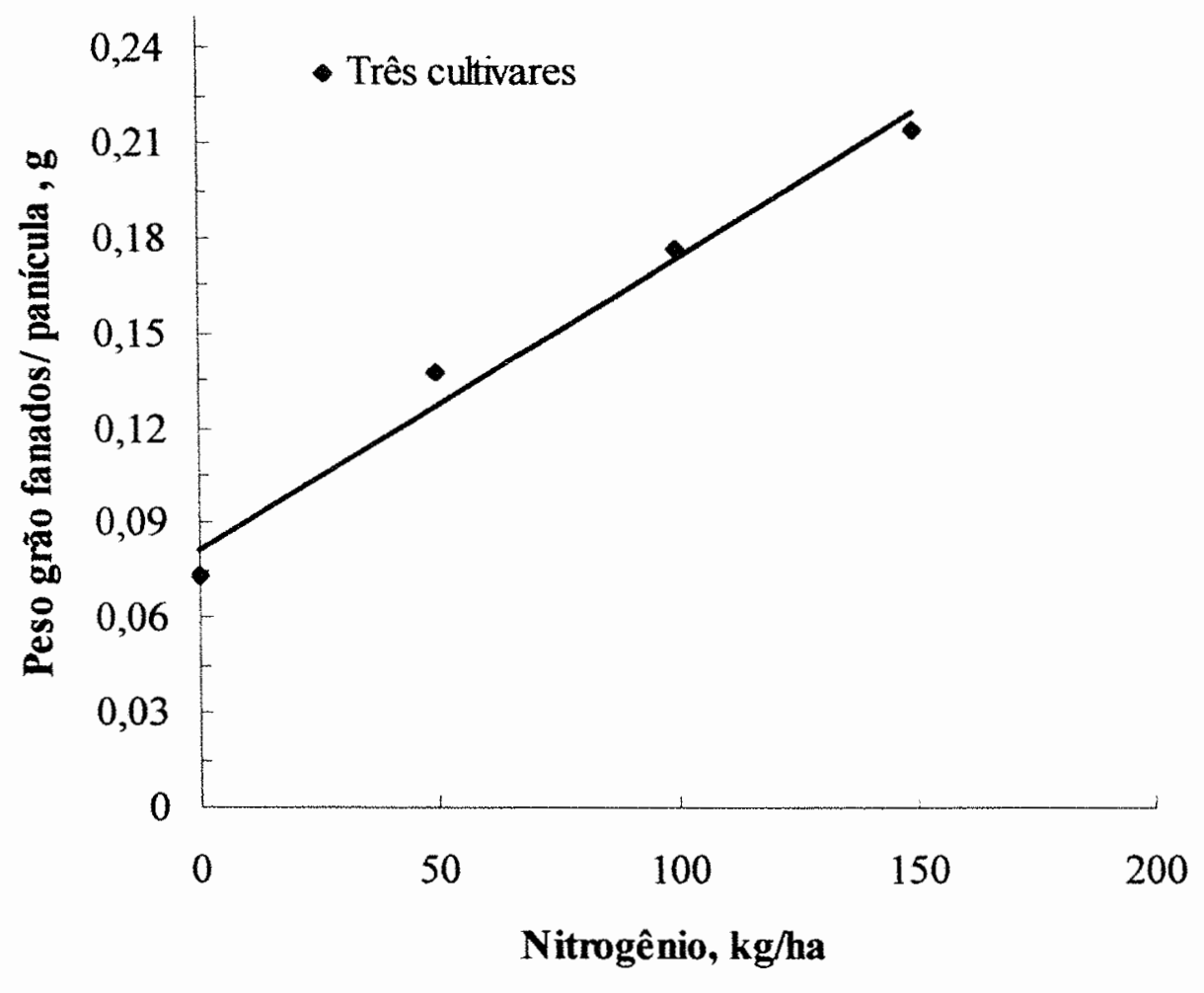

Figura 9. Curva de resposta do peso de grãos fanados por panícula dos três cultivares estudados. 


\subsection{Peso de 1000 grãos}

$\mathrm{Na}$ análise da variância foram encontrados valores de $\mathrm{F}$ significativos para cultivares e niveis de nitrogênio.

No Quadro 13 estão expostas as médias de peso de 1000 grãos em gramas, o coeficiente de variação e a diferença mínima significativa.

Quadro 13. Médias de peso de 1000 grãos, em gramas, para 12 tratamentos.

\begin{tabular}{lcccc}
\hline \multicolumn{5}{c}{ Cultivares } \\
\hline Níveis de N & IAC 101 & IAC 102 & IAC 242 & Médias (1) \\
\hline kg/ha & 35,00 & 29,00 & 30,66 & 31,55 \\
0 & 35,00 & 31,00 & 31,66 & 32,55 \\
50 & 36,33 & 31,33 & 31,66 & 33,11 \\
100 & 36,33 & 30,68 & 31,66 & 32,88 \\
150 & $35,66 \mathrm{a}$ & $30,50 \mathrm{c}$ & $31,41 \mathrm{~b}$ & \\
\hline Médias (2) & 1,96 & & & \\
\hline CV\% & 0,65 & & & \\
\hline
\end{tabular}

O teste de Tukey $(\alpha=0,05)$ aplicado às médias de peso de 1000 grãos permitiu constatar que o cultivar IAC 101 superou os demais. O cultivar IAC 242, com média intermediária, foi significativamente superior ao IAC 102.

Todos os cultivares mostraram aumento do peso de 1000 grãos para niveis de nitrogênio.

A análise da variância da regressão polinomial para niveis de nitrogênio mostrou valor de $\mathrm{F}$ significativo para regressão quadrática, conforme a equação polinomial: 
$Y=31,538889+0,0274444 x-0,00012222 x^{2}$, com $^{2}=0,99$

onde:

Yé a variável dependente (peso de 1000 grãos); e

X é a variável independente (níveis de nitrogênio).

A curva de resposta exibida na Figura 10 mostra os efeitos dos níveis de nitrogênio sobre o comportamento dos 3 cultivares em peso de 1000 grãos.

Observa-se que maiores ganho de peso de 1000 grãos ocorreram entre os níveis 0 e $50 \mathrm{~kg}$ de $\mathrm{N} / \mathrm{ha}$, estabilizando-se em $100 \mathrm{~kg}$ de $\mathrm{N} / \mathrm{ha}$, com tendência de diminuição para aplicação de quantidades maiores de nitrogênio.

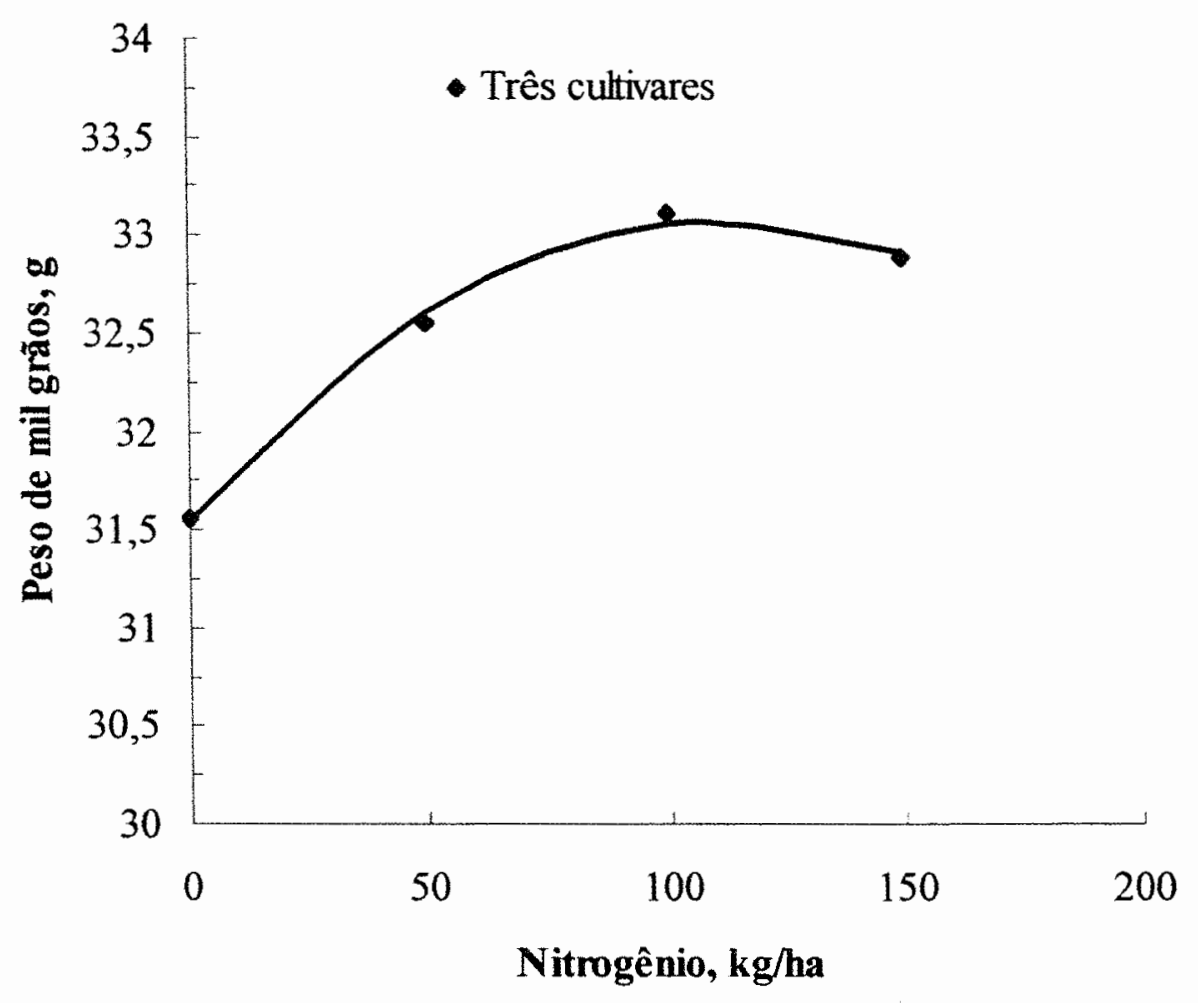

Figura 10. Curva de resposta, em peso de 1000 grãos, de três cultivares de arroz irrigado, submetidos a diferentes niveis de nitrogênio. 


\subsection{Dimensões dos grãos}

\subsubsection{Comprimento de grãos}

$\mathrm{Na}$ análise da variância encontrou-se valores de $\mathrm{F}$ significativos para cultivares e níveis de nitrogênio.

No Quadro 14, encontram-se as médias de comprimento de grãos, coeficiente de variação e diferença mínima significativa.

Quadro 14. Médias de comprimento de grãos, em milímetros, para 12 tratamentos

\begin{tabular}{lcccc}
\hline \multicolumn{5}{c}{ Cultivares } \\
\hline Niveis de N & IAC 101 & IAC 102 & IAC 242 & Médias (1) \\
\hline $\mathrm{kg} / \mathrm{ha}$ & 11,24 & 10,75 & 10,12 & 10,70 \\
0 & 11,40 & 11,24 & 10,29 & 10,98 \\
50 & 11,54 & 11,00 & 10,33 & 10,95 \\
100 & 11,48 & 11,00 & 10,33 & 10,93 \\
\hline 150 & $11,41 \mathrm{a}$ & $11,00 \mathrm{~b}$ & $10,27 \mathrm{c}$ & \\
\hline Médias (2) & 1,72 & & & \\
\hline CV\% & 0,19 & & & \\
\hline D.M.S. (5\%) & & & & \\
\hline
\end{tabular}

Comparando-se as médias de comprimento de grãos do quadro 14 pelo teste de Tukey $(\alpha=0,05)$ verificou-se que os dois cultivares diferiram do IAC 101, que superou os demais, e o cultivar IAC 102, com média intermediária, foi significativamente superior ao IAC 242.

A análise de regressão polinomial para niveis de nitrogênio mostrou valor de F significativo para regressão quadrática dado pela equação polinomial: 


$$
Y=10,7215+0,005722 x-0,00002944 x^{2}, \operatorname{com}^{2}=0,90
$$

onde:

Y é a variável dependente (comprimento de grãos); e

X é a variável independente (níveis de nitrogênio).

A Figura 11 exibe a curva de resposta do comprimento de grãos dos três cultivares, para niveis crescentes de nitrogênio.

Nota-se, pela figura 11, que os maiores ganhos para comprimento de grãos estão entre os niveis 0 e $50 \mathrm{~kg}$ de $\mathrm{N} / \mathrm{ha}$, com tendência de diminuição para nível de $100 \mathrm{~kg}$ de $\mathrm{N} / \mathrm{ha}$, a partir do qual a curva passa a exibir um declínio.

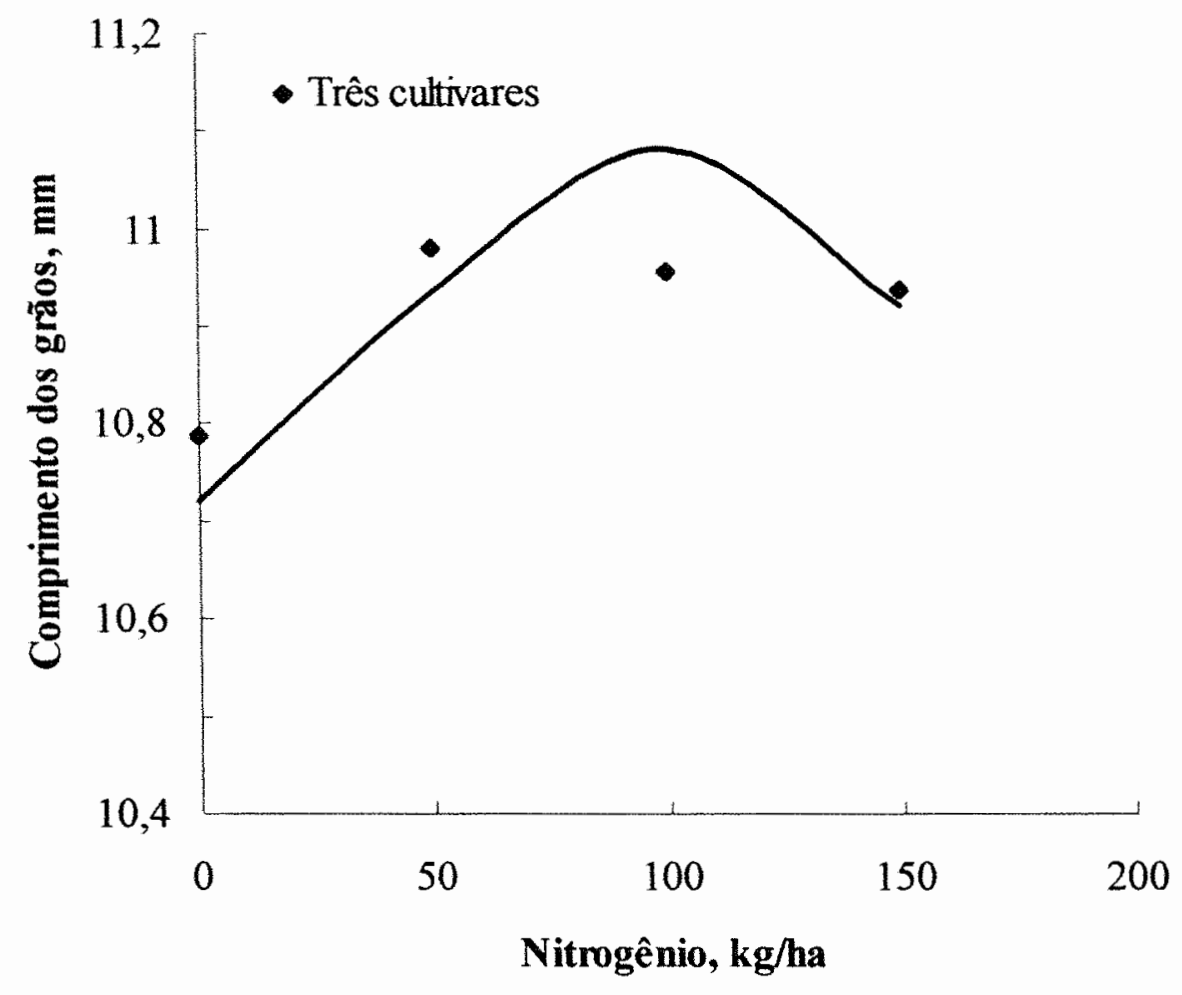

Figura 11. Curva de resposta dos cultivares IAC 101, IAC 102 e IAC 242 aos quatro níveis de nitrogênio. 


\subsubsection{Largura de grãos}

A análise da variância apresentou valores de $\mathrm{F}$ significativos para cultivares e níveis de nitrogênio.

Encontram-se no Quadro 15, as médias de largura de grãos em milímetros, o coeficiente de variação e diferença mínima significativa.

Observa-se pelo Quadro 15, que as médias de largura de grãos dos três cultivares, diferiram entre si pelo teste de Tukey $(\alpha=0,05)$, sendo que o IAC 242 superou os demais e o IAC 101, com média intermediária, foi significativamente superior ao IAC 102.

Quadro 15. Médias de largura de grãos, em milímetros, para 12 tratamentos.

\begin{tabular}{lcccc}
\hline \multicolumn{5}{c}{ Cultivares } \\
\hline Níveis de N & IAC 101 & LAC 102 & IAC 242 & Médias (2) \\
\hline $\mathrm{kg} / \mathrm{ha}$ & 2,71 & 2,50 & 2,80 & 2,67 \\
0 & 2,72 & 2,55 & 2,78 & 2,68 \\
50 & 2,72 & 2,54 & 2,83 & 2,70 \\
100 & 2,74 & 2,55 & 2,80 & 2,70 \\
150 & $2,72 \mathrm{~b}$ & $2,53 \mathrm{c}$ & $2,80 \mathrm{a}$ & \\
\hline Médias (2) & 1,10 & & & \\
\hline CV\% & 0,30 & & & \\
\hline D.M.S. (5\%) & & & \\
\hline
\end{tabular}

A análise de regressão polinomial mostrou efeito linear significativo para níveis de nitrogênio dado pela equação polinomial:

$Y=2,675222+0,0002156 x$, com $r^{2}=0,98$

onde:

Y é a variável dependente (largura de grãos); e

$\mathrm{X}$ é a variável independente (niveis de nitrogênio). 


\subsubsection{Espessura de grãos}

A análise da variància revelou valor de $\mathrm{F}$ significativo para cultivares.

No Quadro 16 são apresentadas as médias de espessura de grãos, coeficiente de variação e diferença mínima significativa.

Quadro 16. Médias de espessura de grãos, em milímetros, para 12 tratamentos.

\begin{tabular}{lcccc}
\hline \multicolumn{5}{c}{ Cultivares } \\
\hline Niveis de N & IAC 101 & IAC 102 & IAC 242 & Médias (2) \\
\hline $\mathrm{kg} /$ ha & & 2,10 & 2,08 & $2,13 \mathrm{a}$ \\
0 & 2,20 & 2,14 & 2,12 & 2,15 \\
50 & 2,18 & 2,11 & 2,13 & 2,15 \\
100 & 2,21 & 2,12 & 2,09 & 2,14 \\
150 & 2,21 & $2,11 \mathrm{~b}$ & $2,10 \mathrm{~b}$ & \\
\hline Médias (2) & $2,20 \mathrm{a}$ & & & \\
\hline D.M.S. (5\%) & 0,28 & & \\
\hline
\end{tabular}

As médias de espessura de grãos apresentadas no quadro 16 revelam que $o$ cultivar IAC 101 superou os demais cultivares que não diferiram significativamente entre si, pelo teste de Tukey $(\alpha=0,05)$.

\subsection{Produção de grãos}

A análise da variância revelou valores significativos de $\mathrm{F}$ para níveis de nitrogênio.

No Quadro 17 são apresentados os resultados de produção em $\mathrm{kg} / \mathrm{ha}$ de arroz, com $13 \%$ de umidade, o coeficiente de variação e a diferença mínima significativa. 
Quadro 17. Produção de arroz, em kg/ha, para 12 tratamentos.

\begin{tabular}{lcccc}
\hline \multicolumn{5}{c}{ Cultivares } \\
\hline Niveis de N & IAC 101 & IAC 102 & IAC 242 & Médias \\
\hline & & $-\mathrm{kg} / \mathrm{ha}$ & & \\
\hline 0 & 3193 & 2767 & 3368 & 3109 \\
50 & 4310 & 4482 & 4186 & 4326 \\
100 & 5404 & 4877 & 5377 & 5219 \\
150 & 5942 & 5783 & 5809 & 5845 \\
\hline Médias & $4712 \mathrm{a}$ & $4477 \mathrm{a}$ & $4685 \mathrm{a}$ & \\
\hline CV \% & 9,29 & & & \\
D.M.S. (5\%) & 441,25 & & & \\
\hline
\end{tabular}

O teste de Tukey $(\alpha=0,05)$ aplicado sobre as médias de produção de grãos permitiu constatar que os cultivares estudados não diferiram significativamente entre si.

A análise da variância da regressão polinomial para niveis de nitrogênio, mostrou valor de $\mathrm{F}$ significativo para regressão quadrática, conforme equação polinomial:

$$
Y=3112,477778+27,0662222 x-0,05911111 x^{2}, \operatorname{com~r}^{2}=1,0
$$

onde:

Y é a variável dependente (produção de grãos/ha); e

$\mathrm{X}$ é a variável independente (níveis de nitrogênio).

A curva de resposta da Figura 12, mostra o efeito de quatro níveis de nitrogênio sobre o rendimento de grãos, em $\mathrm{kg} / \mathrm{ha}$, dos cultivares de arroz IAC 101, IAC 102 e IAC 242. 


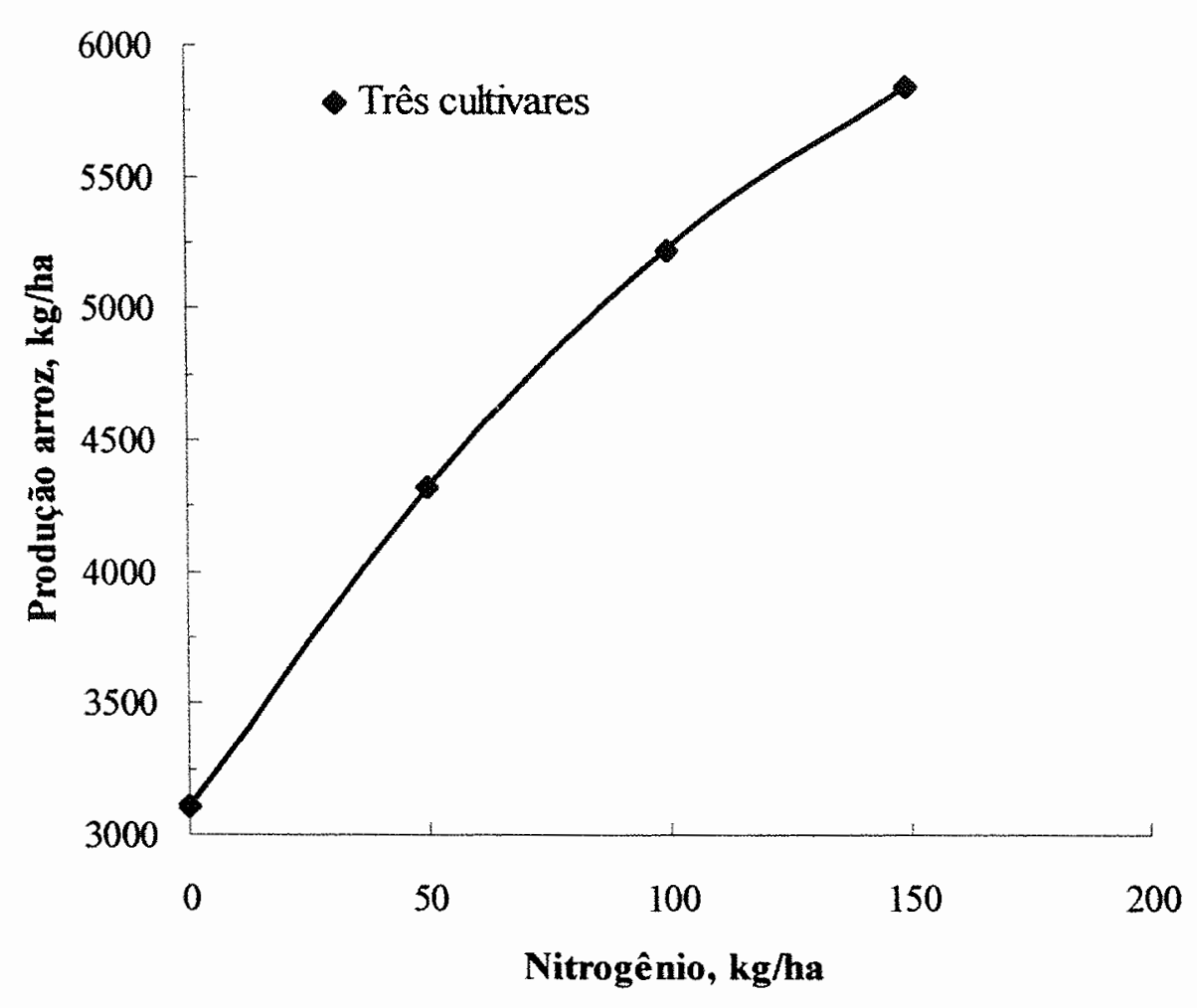

Figura 12. Curva de resposta de produção de grãos em casca dos cultivares aos quatro niveis de nitrogênio.

Os efeitos dos níveis de nitrogênio sobre a produção de arroz dos 3 cultivares, observadas na curva de resposta da figura 12 , revelam maiores ganhos entre os niveis 0 e $100 \mathrm{~kg}$ de $\mathrm{N} / \mathrm{ha}$, embora para $150 \mathrm{~kg}$ de $\mathrm{N} / \mathrm{ha}$ a curva ainda se encontra em ascensão, mostrando tendência de estabilidade da produção de grãos para niveis de nitrogênio, superior ao nível máximo estudado.

Derivando-se a equação de regressão polinomial (18), calculou-se que o nível de nitrogênio de máxima resposta é de $229 \mathrm{~kg}$ de $\mathrm{N} / \mathrm{ha}$, com o qual através da equação (18) obteve-se produção máxima de $6212 \mathrm{~kg}$ de grãos $/ \mathrm{ha}$. 


\subsection{Rendimento de grãos no beneficiamento}

\subsubsection{Peso de grãos inteiros beneficiados}

A análise da variância mostrou valores de F significativos para cultivares e níveis de nitrogênio.

$\mathrm{Na}$ análise estatística os dados obtidos em porcentagem foram transformados em arco seno $\sqrt{ } \mathrm{x} / 100$, porém, no Quadro 18 , estão expostos os dados originais do coeficiente de variação e diferença mínima significativa.

As médias de peso de grãos inteiros no beneficiamento (quadro 18), revelam que o cultivar IAC 242 superou os demais cultivares, que não diferiram significativamente entre si pelo teste de Tukey $(\alpha=0,05)$.

A análise de regressão polinomial revelou efeito linear significativo para os níveis de nitrogênio dado pela equação polinomial:

$$
\mathrm{Y}=45,700000+0,0751111 x, \text { com } r^{2}=0,99
$$

onde:

Y é a variável dependente (rendimento industrial); e

$\mathrm{X}$ é a variável independente (niveis de nitrogênio).

Os efeitos dos níveis crescentes de nitrogênio sobre os cultivares IAC 101, IAC 102 e IAC 242, conforme as médias de peso de grãos inteiros beneficiados expostas no quadro 18, encontram-se representados pela curva de resposta na Figura 13. 
Quadro 18. Médias do peso de grãos inteiros beneficiados, em gramas, para 12 tratamentos.

\begin{tabular}{lcccc}
\hline \multicolumn{5}{c}{ Cultivares } \\
\hline Niveis de N & IAC 101 & IAC 102 & IAC 242 & Médias (1) \\
\hline $\mathrm{kg} / \mathrm{ha}$ & 39,00 & 45,33 & 52,00 & 45,44 \\
0 & 45,00 & 48,33 & 55,33 & 49,55 \\
50 & 53,00 & 52,66 & 55,66 & 53,77 \\
100 & 54,00 & 55,66 & 60,00 & 56,55 \\
\hline 150 & $47,75 \mathrm{~b}$ & $50,50 \mathrm{~b}$ & $55,75 \mathrm{a}$ & \\
\hline Médias (2) & 9,00 & & & \\
\hline CV \% & 4,74 & & & \\
\hline
\end{tabular}

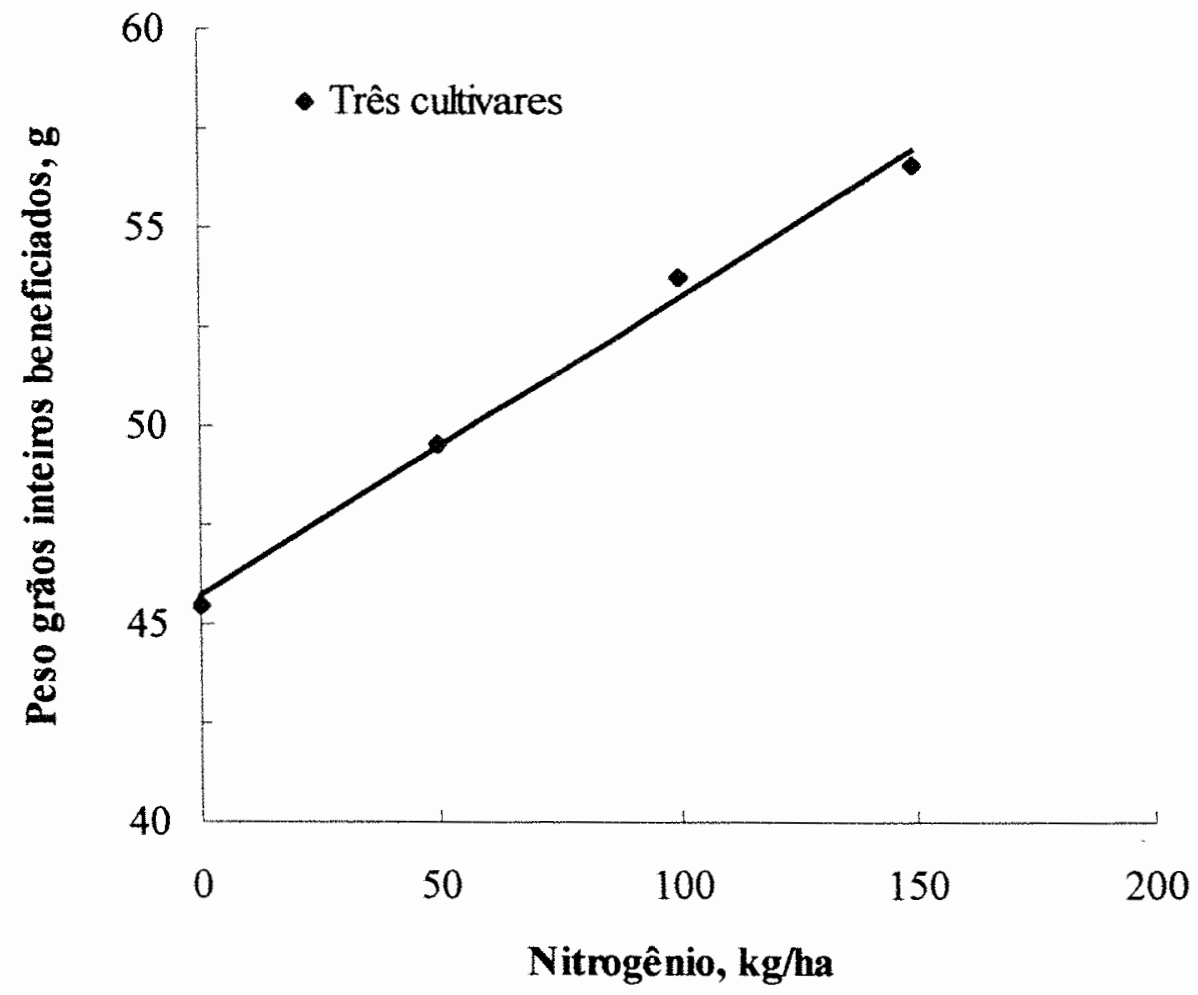

Figura 13. Curva de resposta do peso de grãos inteiros beneficiados dos três cultivares de arroz aos quatro níveis de nitrogênio. 


\subsubsection{Peso de grãos quebrados beneficiados}

$\mathrm{Na}$ análise da variância foram encontrados valores de $\mathrm{F}$ significativos para cultivares e niveis de nitrogênio.

Os dados obtidos em porcentagem, na análise estatística, foram transformados em arco seno $\bigvee_{x} / 100$ porém, no Quadro 19 abaixo estão expostos os dados originais, o coeficiente de variação e diferença mínima significativa.

Quadro 19. Médias de peso de grãos quebrados beneficiados, em gramas, para 12 tratamentos.

\begin{tabular}{lcccc}
\hline \multicolumn{5}{c}{ Cultivares } \\
\hline Niveis de N & IAC 101 & IAC 102 & IAC 242 & Médias (2) \\
\hline $\mathrm{kg} /$ ha & 32,33 & 24,66 & 18,00 & 25,00 \\
0 & 25,00 & 22,00 & 14,33 & 20,44 \\
50 & 15,66 & 17,66 & 14,33 & 15,88 \\
100 & 15,00 & 15,66 & 10,00 & 13,55 \\
150 & $22,00 \mathrm{a}$ & $20,00 \mathrm{a}$ & $14,16 \mathrm{~b}$ & \\
\hline Médias (1) & 23,50 & & & \\
\hline CV \% & 4,51 & & & \\
\hline D.M.S. (5\%) & & & \\
\hline
\end{tabular}

O teste de Tukey $(\alpha=0,05)$ aplicado sobre as médias de peso de grãos quebrados beneficiados permitiu constatar que os cultivares IAC 101 e IAC 102 foram iguais entre si e superiores ao IAC 242.

A análise de regressão polimonial revelou efeito linear significativo para os níveis de nitrogênio, conforme a equação polimonial:

$$
Y=24,555556-0,0777778 x, \text { com } r^{2}=0,99
$$


onde:

Y é a variável dependente (peso de grãos quebrados); e

X é a variável independente (níveis de nitrogênio).

Os efeitos dos níveis crescentes de nitrogênio sobre as médias de peso de grãos quebrados beneficiados expostas no quadro 19 , estão representados pela curva de resposta na Figura 14.

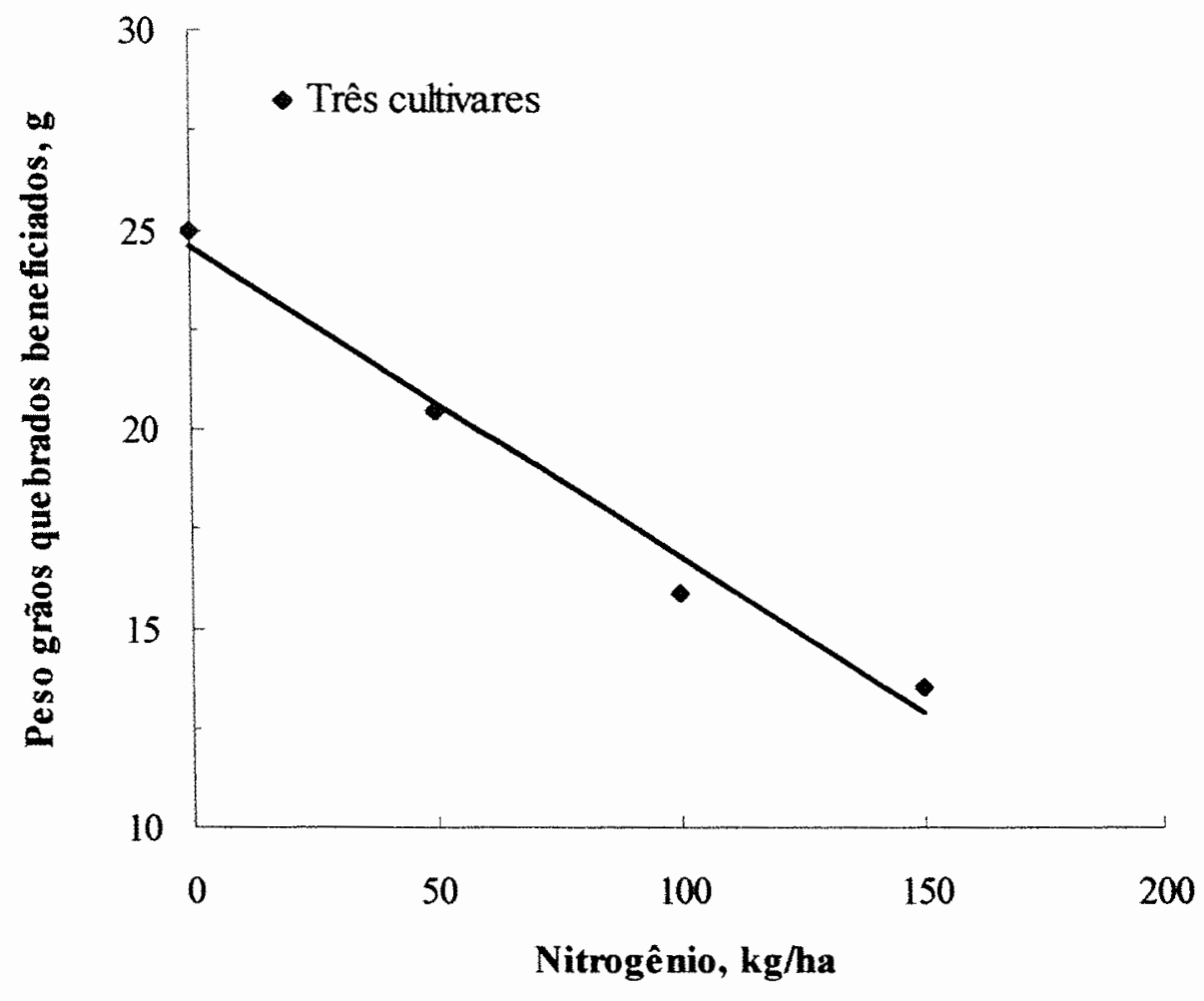

Figura 14. Curva de resposta dos pesos de grãos quebrados beneficiados dos cultivares de arroz aos níveis crescentes de nitrogênio. 


\subsubsection{Renda do beneficiamento}

A análise da variância acusou valor de $\mathrm{F}$ significativo para interação cultivares $\mathrm{x}$ nitrogênio.

$\mathrm{Na}$ análise estatística os dados obtidos em porcentagem foram transformados em arco seno $\sqrt{ } \mathrm{x} / 100$, estando expostos no Quadro 20 , os dados originais, o coeficiente de variação e diferença minima significativa.

As médias da renda do beneficiamento do quadro 20 mostram que não houve diferenças significativas entre cultivares, todavia pelo teste de Tukey $(\alpha=0,05)$, aplicado para médias da renda do beneficiamento dos cultivares dentro de cada nível do fator nitrogênio, verificou-se que para o nível 0 de nitrogênio, o cultivar IAC 101 foi superior ao IAC 102 e não diferiu do IAC 242, o qual foi estatisticamente igual ao IAC 102.

Para o nível de $150 \mathrm{~kg}$ de N/ha, o cultivar IAC 102 foi superior ao IAC 101 e não diferiu do IAC 242, o qual foi estatisticamente igual ao IAC 101.

Nos níveis intermediários de nitrogênio, 50 e $100 \mathrm{~kg}$ de $\mathrm{N} / \mathrm{ha}$ os três cultivares não diferiram significativamente entre si.

A análise de regressão polinomial para niveis de nitrogênio mostrou valor de F significativo para regressão quadrática, dado pela equação polinomial:

$$
\mathrm{Y}=71,000000-0,0255556 \mathrm{X}+0,0005556 \mathrm{x}^{2}
$$

$\operatorname{com} r^{2}=1,00$

onde:

Y é a variável dependente (renda); e

$\mathrm{X}$ é a variável independente (niveis de nitrogênio). 
Tendo em vista a significância apresentada pela interação cultivar $\mathrm{x}$ nitrogênio aplicou-se a análise de regressão polinomial em relação aos níveis de nitrogênio dentro do fator cultivar, individualmente.

No cultivar IAC 101 obteve-se valor de F significativo, com efeito quadrático negativo dado pela equação polinomial:

$Y=71,933333-0,0546667 x+0,0026667 x^{2}$ com r ${ }^{2}=0,98$

onde:

Y é a variável dependente (renda); e

X é a variável independente (níveis de nitrogênio).

Para o cultivar IAC 102 obteve-se valor de F significativo para efeito linear conforme a equação polinomial:

$$
\mathrm{Y}=70,000000+0,0100000 x, \operatorname{com~r}^{2}=0,88
$$

Quadro 20. Médias da renda do beneficiamento (peso de grãos inteiros mais peso de grãos quebrados ), em gramas, para 12 tratamentos.

\begin{tabular}{lcccc}
\hline \multicolumn{5}{c}{ Cultivares } \\
\hline Niveis de N & LAC 101 & IAC 102 & IAC 242 & Médias (1) \\
\hline kg/ha & & & & \\
\hline 0 & $72,00 \mathrm{a}$ & $70,00 \mathrm{~b}$ & $71,00 \mathrm{ab}$ & 71,00 \\
50 & $69,66 \mathrm{a}$ & $70,66 \mathrm{a}$ & $70,00 \mathrm{a}$ & 70,10 \\
100 & $69,33 \mathrm{a}$ & $70,66 \mathrm{a}$ & $70,00 \mathrm{a}$ & 70,00 \\
150 & $69,66 \mathrm{~b}$ & $71,66 \mathrm{a}$ & $70,66 \mathrm{ab}$ & 70,66 \\
\hline Médias (2) & $70,16 \mathrm{a}$ & $70,74 \mathrm{a}$ & $70,41 \mathrm{a}$ & \\
\hline CV \% & 1,27 & & & \\
\hline D.M.S. (5\%) & 0,92 & & & \\
D.M.S. (5\%) & 1,83 & & & \\
\hline
\end{tabular}

* cultivares $\quad$ ** cultivares dentro de nitrogênio 


\subsection{Produção de grãos inteiros beneficiados}

A análise da variância mostrou valores de $\mathrm{F}$ significativos para cultivares e níveis de nitrogênio.

As médias de produção de grãos inteiros de arroz beneficiado, em $\mathrm{kg} / \mathrm{ha}$, o coeficiente de variação e a diferença mínima significativa, encontram-se no Quadro 21.

Quadro 21. Produção de grãos inteiros de arroz, em kg/ha, para 12 tratamentos.

\begin{tabular}{lcccc}
\hline \multicolumn{5}{c}{ Cultivares } \\
\hline Níveis de N & IAC 101 & IAC 102 & IAC 242 & Médias (1) \\
\hline 0 & 1244 & 1262 & 1768 & 1425 \\
50 & 1963 & 2200 & 2330 & 2164 \\
100 & 2894 & 2599 & 3022 & 2838 \\
150 & 3250 & 3262 & 3523 & 3345 \\
\hline Médias (2) & 2338 a & $2331 \mathrm{a}$ & 2661 a & \\
\hline CV \% & 13,29 & & & \\
D.M.S. (5\%) & 333,28 & & & \\
\hline
\end{tabular}

As médias de produção de grãos inteiros apresentadas permitem constatar no quadro 21 , que os cultivares não diferiram significativamente entre si, pelo teste de Tukey $(\alpha=0,05)$, embora o cultivar IAC 242 apresentou maiores médias que os demais cultivares estudados.

Tendo em vista a significância apresentada para nitrogênio, foi feita a análise da variância da regressão polinomial para níveis de nitrogênio, que revelou valor de F significativo para regressão linear, conforme a equação polinomial: 
$Y=1477,711111+12,8708889 x \operatorname{com} r^{2}=0,99$

onde:

Y é a variável dependente (produção de grãos inteiros/ha); e

X é a variável independente (níveis de nitrogênio).

A Figura 15 mostra a curva de resposta dos cultivares IAC 101, IAC 102 e IAC 242, em grãos inteiros beneficiados por hectare, à 4 níveis de adubação nitrogenada.

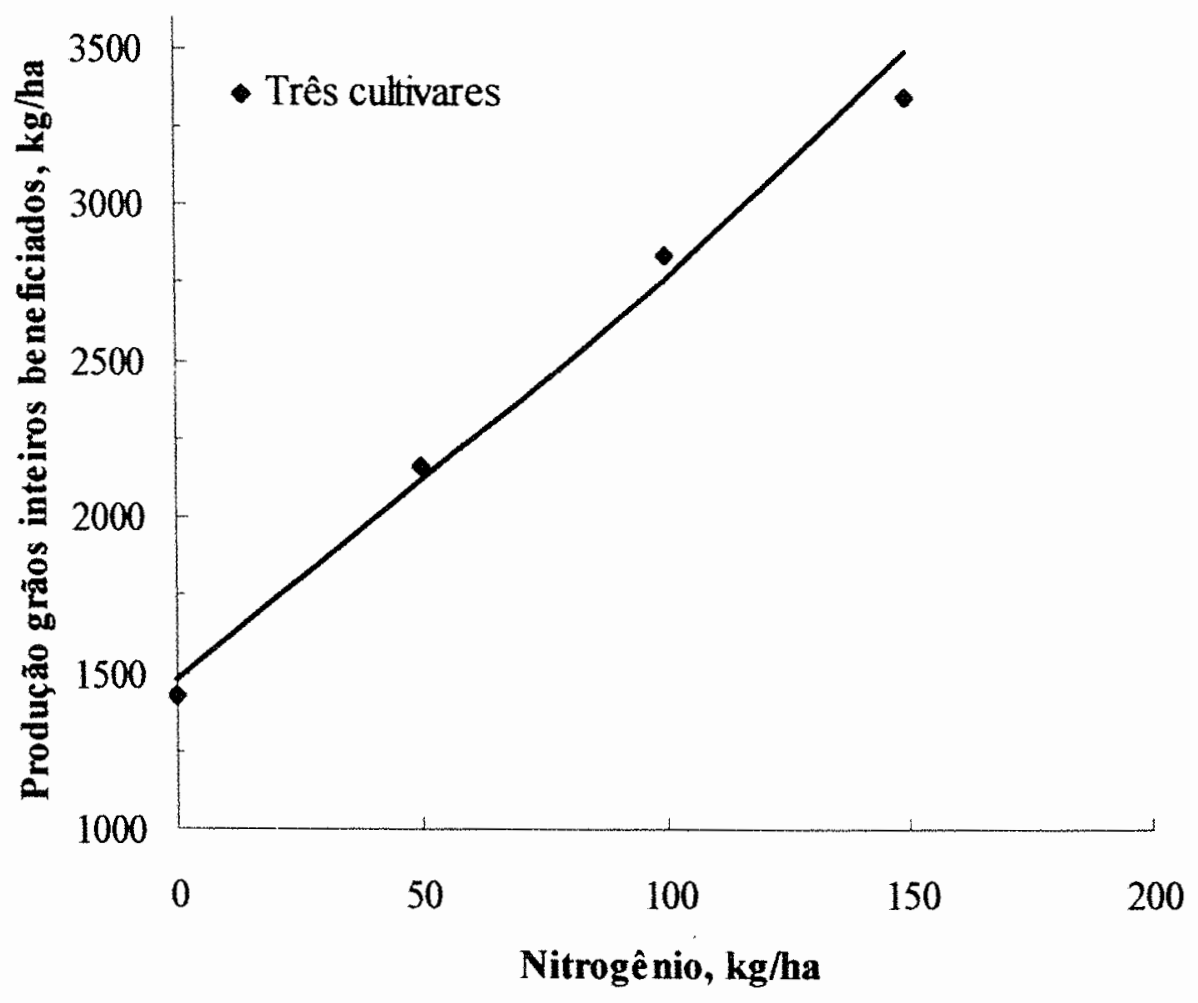

Figura 15. Curva de resposta de produção de grãos inteiros beneficiados dos três cultivares aos quatro níveis de nitrogênio. 


\subsection{Produção de grãos quebrados beneficiados}

A análise da variância acusou valor de $F$ significativo somente para cultivares.

No Quadro 22 são apresentados as produções médias de grãos de arroz quebrados, em $\mathrm{kg} / \mathrm{ha}$, após a operação de beneficiamento, bem como o coeficiente de variação e a diferença mínima significativa.

Quadro 22. Médias de produção de grãos quebrados beneficiados, em $\mathrm{kg} / \mathrm{ha}$, para 12 tratamentos.

\begin{tabular}{lcccc}
\hline \multicolumn{5}{c}{ Cultivares } \\
\hline Níveis de N & LAC 101 & LAC 102 & IAC 242 & Médias (1) \\
\hline 0 & 1068 & 692 & 629 & 796 \\
50 & 1093 & 998 & 629 & 907 \\
100 & 872 & 872 & 779 & 845 \\
150 & 907 & 915 & 593 & 805 \\
\hline Médias (2) & $985 \mathrm{a}$ & $872 \mathrm{a}$ & $657 \mathrm{~b}$ & \\
\hline CV \% & 24,22 & & & \\
D.M.S. (5\%) & 208,41 & & & \\
\hline
\end{tabular}

Aplicando-se o teste de Tukey $(\alpha=0,05)$ sobre as médias de produção de grãos quebrados do quadro 22, observou-se que os cultivares IAC 101 e IAC 102 foram iguais entre si e superiores ao cultivar IAC 242.

As produções médias de grãos quebrados, em $\mathrm{kg} / \mathrm{ha}$, dos cultivares IAC 101, IAC 102 e IAC 242, após o beneficiamento, encontram-se representadas na Figura 16. 
.74

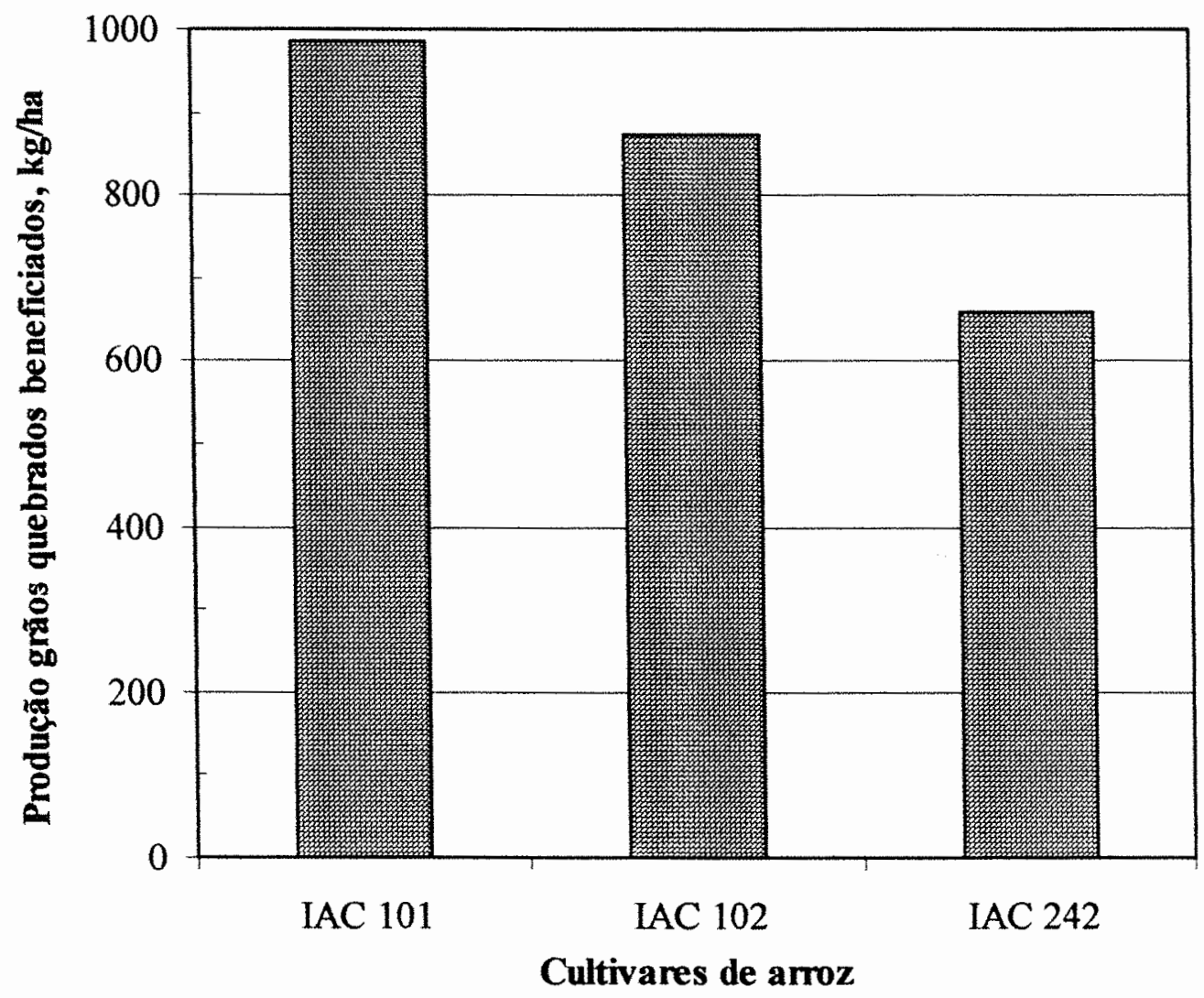

Figura 16. Produções de grãos quebrados de três cultivares de arroz no beneficiamento. 


\subsection{Germinação}

\subsubsection{Plântulas normais}

A análise da variância acusou valores de $\mathrm{F}$ significativo para cultivares.

No Quadro 23 encontram-se as médias de germinação obtidas em porcentagem e transformadas em arco seno da raiz de $\mathrm{x} / 100$, coeficientes de variação e diferença minima significativa.

Quadro 23. Porcentagens médias de plântulas normais para 12 tratamentos transformados em arco seno $\sqrt{x} / 100$

\begin{tabular}{|c|c|c|c|c|}
\hline \multicolumn{5}{|c|}{ Cultivares } \\
\hline Níveis de $\mathbf{N}$ & IAC 101 & IAC 102 & IAC 242 & Médias (1) \\
\hline $\mathrm{kg} / \mathrm{ha}$ & (-ב_ב-ב & - & - & - \\
\hline 0 & 71 & 76 & 65 & 70,66 \\
\hline 50 & 71 & 76 & 70 & 72,33 \\
\hline 100 & 72 & 71 & 73 & 72,00 \\
\hline 150 & 71 & 75 & 69 & 71,66 \\
\hline Médias (2) & $71,25 \mathrm{ab}$ & $74,50 \mathrm{a}$ & $69,25 \mathrm{~b}$ & \\
\hline $\mathrm{CV} \%$ & 4,98 & & & \\
\hline D.M.S. (5\%) & 3,68 & & & \\
\hline
\end{tabular}

Pelas médias de plântulas normais apresentadas no quadro 23, observa-se que o cultivar IAC 102 foi superior ao IAC 242 e não diferiu do IAC 101, o qual foi estatisticamente igual ao IAC 242 pelo teste de Tukey $(\alpha=0,05)$.

As médias de plântulas normais originais de tratamentos referentes aos cultivares IAC 101, IAC 102 e IAC 242 estão expostas na Figura 17. 


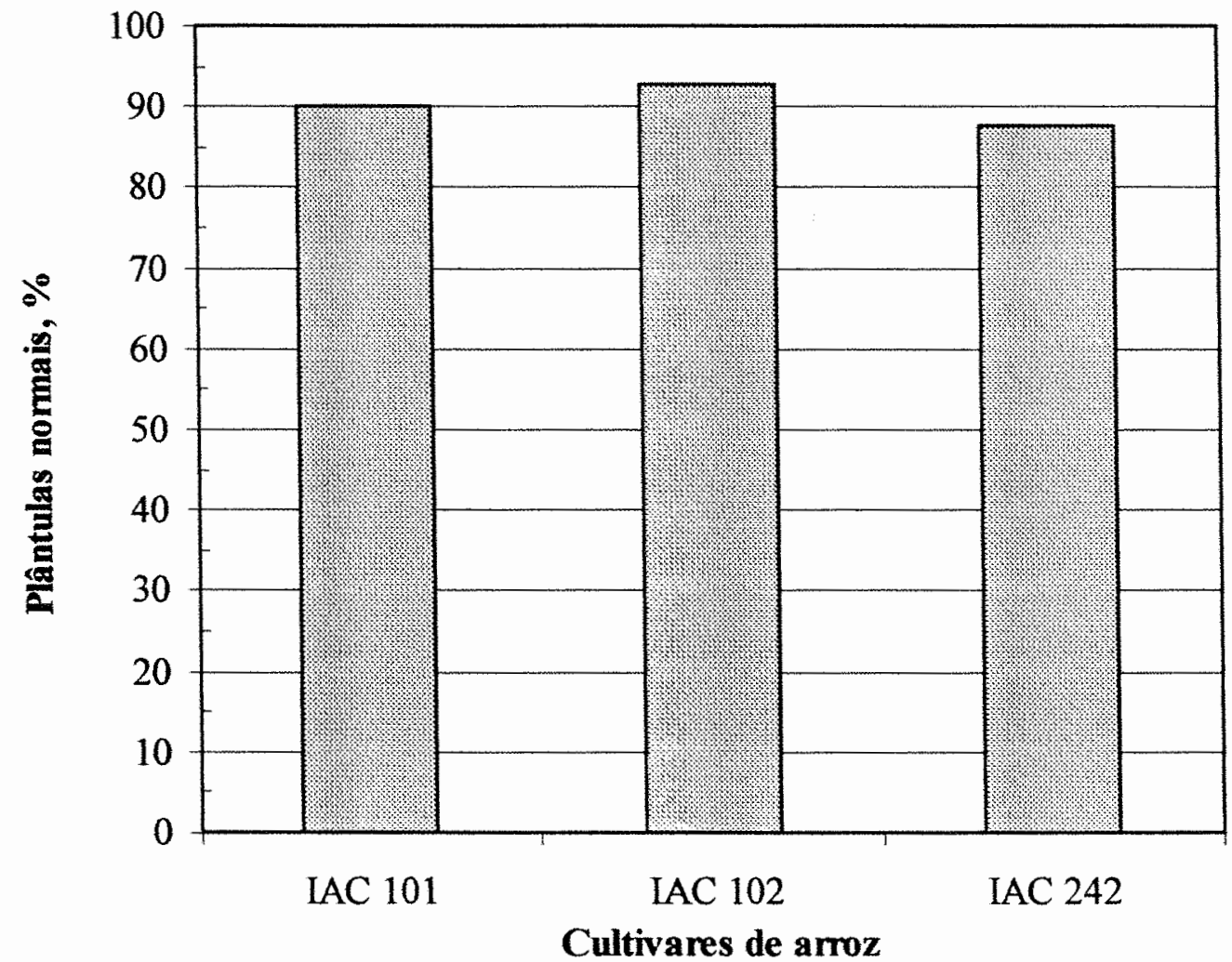

Figura 17. Médias de plântulas normais apresentadas pelos cultivares de arroz estudados. 


\subsubsection{Plântulas anormais}

$\mathrm{Na}$ análise da variância foi encontrado valor de $\mathrm{F}$ significativo ao nível de $5 \%$ de probabilidade para cultivares.

No Quadro 24 são apresentadas as médias de plântulas anormais obtidas em porcentagem e transformadas em arco seno da raiz de $\mathrm{x} / 100$, o coeficiente de variação e a diferença mínima significativa.

Quadro 24. Porcentagens médias de plântulas anormais para 12 tratamentos, transformadas em arco seno $\sqrt{ } \mathrm{x} / 100$.

\begin{tabular}{lcccc}
\hline \multicolumn{5}{c}{ Cultivares } \\
\hline Niveis de N & IAC 101 & IAC 102 & IAC 242 & Médias (1) \\
\hline kg/ha & 1,91 & 3,82 & 8,13 & 4,62 \\
0 & 3,82 & 2,71 & 3,82 & 3,45 \\
50 & 2,71 & 5,23 & 7,15 & 5,03 \\
100 & 1,91 & 1,91 & 7,33 & 3,71 \\
\hline 150 & $2,59 \mathrm{~b}$ & $3,42 \mathrm{ab}$ & $6,61 \mathrm{a}$ & \\
\hline Médias (2) & 83,05 & & & \\
\hline CV \% & 3,58 & & & \\
\hline D.M.S. (5\%) & & & \\
\hline
\end{tabular}

Pelo teste de Tukey $(\alpha=0,05)$ aplicado sobre as médias de plântulas anormais exibidas no quadro 24 , verifica-se que o cultivar IAC 242 foi superior ao IAC 101 e não diferiu do IAC 102, o qual foi estatisticamente igual ao IAC 101. 


\subsubsection{Plântulas infectadas}

A análise da variância revelou valor de F significativo para cultivares.

No Quadro 25 estão expostas as médias de plântulas infectadas obtidas em porcentagem e transformadas em arco seno da raiz de x/100, o coeficiente de variação e a diferença mínima significativa.

Quadro 25. Porcentagens médias de plântulas infectadas para 12 tratamentos, transformadas em arco seno $\sqrt{x}_{\mathrm{x}} / 100$.

\begin{tabular}{lcccc}
\hline \multicolumn{5}{c}{ Cultivares } \\
\hline Niveis de N & IAC 101 & IAC 102 & IAC 242 & Médias (1) \\
\hline kg/ha & & & $\%$ & \\
\hline 0 & 11,87 & 6,53 & 17,30 & 11,98 \\
50 & 12,35 & 5,76 & 13,91 & 10,69 \\
100 & 9,35 & 11,89 & 9,88 & 10,37 \\
150 & 11,48 & 8,93 & 9,73 & 10,04 \\
\hline Médias (2) & 11,26 ab & $8,27 \mathrm{~b}$ & $12,70 \mathrm{a}$ & \\
\hline CV \% & 33,42 & & & \\
\hline D.M.S. (5\%) & 3,69 & & \\
\hline
\end{tabular}

Verifica-se pelo quadro 25 que o cultivar IAC 242 superou o IAC 102 e não diferiu do IAC 101, que foi estatisticamente igual ao IAC 102 pelo teste de Tukey $(\alpha=0,05)$.

Na Figura 18 encontram-se representadas as médias originais de plântulas infectadas, referentes aos cultivares de arroz IAC 101, IAC 102 e IAC 242. 
79.

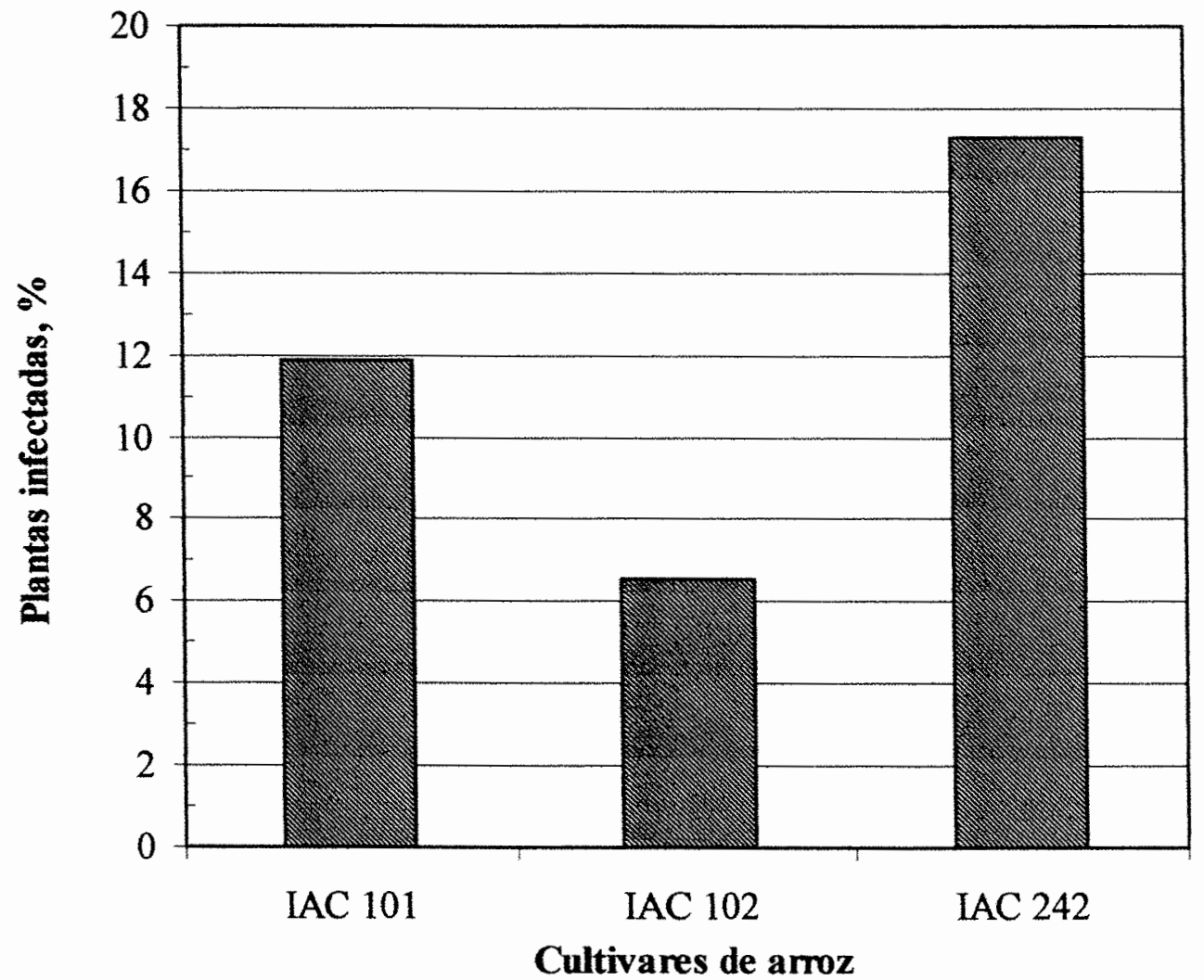

Figura 18. Médias de plântulas infectadas, apresentadas pelos cultivares estudados. 


\subsubsection{Sementes mortas}

A análise da variância não revelou valores de F significativos para todas as causas de variação.

No Quadro 26 são apresentadas as médias de sementes mortas obtidas em porcentagem e transformadas em arco seno da raiz de $\mathrm{x} / 100$, o coeficiente de variação e a diferença mínima significativa.

Quadro 26. Porcentagens médias de sementes mortas para 12 tratamentos transformadas em arco seno $\sqrt{x} / 100$

\begin{tabular}{lcccc}
\hline \multicolumn{5}{c}{ Cultivares } \\
\hline Niveis de N & IAC 101 & IAC 102 & IAC 242 & Médias (1) \\
\hline $\mathrm{kg} /$ ha & 13,34 & 10,30 & 14,85 & 12,83 \\
0 & 12,46 & 10,95 & 12,93 & 12,11 \\
50 & 13,72 & 12,87 & 11,74 & 12,77 \\
100 & 13,52 & 10,86 & 15,31 & 13,33 \\
\hline 150 & $13,26 \mathrm{a}$ & $11,24 \mathrm{a}$ & $13,70 \mathrm{a}$ & \\
\hline Médias (2) & 26,11 & & & \\
\hline CV \% & 3,41 & & & \\
\hline D.M.S. (5\%) & & & & \\
\hline
\end{tabular}




\subsection{Vigor}

\subsubsection{Plântulas normais}

$\mathrm{Na}$ análise da variância não foi encontrada significância para nenhuma causa de variação.

As médias de plântulas normais obtidas em porcentagem e transformadas em arco seno da raiz de $\mathrm{x} / 100$, o coeficiente de variação e a diferença mínima significativa, encontram-se no Quadro 27.

Quadro 27. Porcentagens médias de plântulas normais para 12 tratamentos, transformadas em arco seno $V_{\mathrm{X}} / 100$

\begin{tabular}{lcccc}
\hline \multicolumn{5}{c}{ Cultivares } \\
\hline Níveis de N & IAC 101 & IAC 102 & IAC 242 & Médias (1) \\
\hline $\mathrm{kg} / \mathrm{ha}$ & & & & \\
\hline 0 & 68 & 63 & 63 & 64,66 \\
50 & 66 & 62 & 62 & 63,33 \\
100 & 63 & 61 & 64 & 62,66 \\
150 & 70 & 68 & 63 & 67,00 \\
\hline Médias (2) & $66,75 \mathrm{a}$ & $65,5 \mathrm{a}$ & $63,00 \mathrm{a}$ & \\
\hline CV \% & 6,57 & & & \\
\hline D.M.S. (5\%) & 4,36 & & & \\
\hline
\end{tabular}




\subsubsection{Plântulas anormais}

A análise da variância revelou valores de $F$ significativos para niveis de nitrogênio.

No Quadro 28 estão expostas as médias de plântulas anormais obtidas em porcentagem e transformadas em arco seno da raiz de $\mathrm{x} / 100$, o coeficiente de variação $\mathrm{e}$ a diferença minima significativa.

Quadro 28. Porcentagens médias de plântulas anormais para 12 tratamentos transformadas em arco seno $V_{x} / 100$.

\begin{tabular}{lcccc}
\hline \multicolumn{5}{c}{ Cultivares } \\
\hline Niveis de N & IAC 101 & LAC 102 & IAC 242 & Médias (1) \\
\hline $\mathrm{kg} / \mathrm{ha}$ & 5,73 & 7,33 & 7,94 & 7,00 \\
0 & 5,23 & 1,91 & 1,91 & 3,02 \\
50 & 0,00 & 3,82 & 3,82 & 2,54 \\
100 & 1,91 & 3,32 & 3,24 & 2,82 \\
\hline 150 & $3,21 \mathrm{a}$ & $4,09 \mathrm{a}$ & $4,22 \mathrm{a}$ & \\
\hline Médias (2) & 94,28 & & & \\
\hline CV \% & 3,73 & & & \\
\hline
\end{tabular}

Verifica-se pelas médias do quadro 28 , que houve drástica diminuição de plântulas anormais entre os niveis 0 e $50 \mathrm{~kg}$ de $\mathrm{N} / \mathrm{ha}$, mantendo-se constante para doses mais elevados. A análise de regressão polinomial revelou efeito quadrático significativo para os niveis de nitrogênio dado pela equação polinomial:

$$
Y=6,869667-0,0901889 x+0,00042888 x^{2}, \text { com r }^{2}=0,97
$$

onde:

Y é a variável dependente (plântulas normais); e

$X$ é a variável independente (níveis de nitrogênio). 


\subsubsection{Plântulas infectadas}

Através da análise da variância não foi constatada significância para nenhuma causa da variação.

Encontram-se expostas no Quadro 29, as médias de plântulas anormais, obtidas em porcentagens e transformadas em arco seno da raiz de $\mathrm{x} / 100$, o coeficiente de variação e a diferença mínima significativa.

Quadro 29. Porcentagens médias de plântulas anormais para tratamentos transformadas em arco seno $\sqrt{ } \mathrm{x} / 100$.

\begin{tabular}{lcccc}
\hline \multicolumn{5}{c}{ Cultivares } \\
\hline Niveis de N & IAC 101 & IAC 102 & IAC 242 & Médias (1) \\
\hline $\mathrm{kg} / \mathrm{ha}$ & & & & \\
0 & 1,91 & 8,13 & 6,53 & 2,52 \\
50 & 2,71 & 5,23 & 1,91 & 3,28 \\
100 & 9,73 & 6,22 & 2,71 & 6,22 \\
150 & 9,36 & 3,82 & 7,94 & 7,04 \\
\hline Médias (2) & $5,93 \mathrm{a}$ & $5,85 \mathrm{a}$ & $4,77 \mathrm{a}$ & \\
\hline CV \% & 69,13 & & & \\
\hline D.M.S. (5\%) & 3,91 & & & \\
\hline
\end{tabular}




\subsubsection{Sementes mortas}

A análise da variância revelou valores de $\mathrm{F}$ significativos para os níveis de nitrogênio.

O Quadro 30 apresenta as médias de plântulas mortas obtidas em porcentagem e transformadas em arco seno da raiz de $\mathrm{x} / 100$, o coeficiente de variação e a diferença minima significativa.

Quadro 30. Porcentagens médias de sementes mortas para tratamentos, transformadas em arco seno $\sqrt{ } \mathrm{x} / 100$.

\begin{tabular}{lcccc}
\hline \multicolumn{5}{c}{ Cultivares } \\
\hline Níveis de $\mathbf{N}$ & IAC 101 & IAC 102 & IAC 242 & Médias (1) \\
\hline $\mathrm{kg} / \mathrm{ha}$ & & & & \\
0 & 21,12 & 24,29 & 19,32 & 21,57 \\
50 & 22,42 & 26,28 & 27,02 & 25,24 \\
100 & 24,40 & 27,06 & 25,30 & 25,58 \\
150 & 16,88 & 20,18 & 24,20 & 20,42 \\
\hline Médias (2) & $21,20 \mathrm{a}$ & $24,45 \mathrm{a}$ & $23,96 \mathrm{a}$ & \\
\hline CV \% & 23,80 & & & \\
\hline D.M.S. (5\%) & 5,67 & & & \\
\hline
\end{tabular}

As médias apresentadas no quadro 30 , revelam aumento de sementes mortas entre os níveis 0 e $50 \mathrm{~kg}$ de N/ha, estabilizando-se até o nível de $100 \mathrm{~kg}$ de N/ha, a partir do qual ocorreu diminuição. A análise de regressão polinomial revela efeito quadrático significativo para os níveis de nitrogênio dado pela equação polinomial:

$$
Y=21,469350+0,1262187 x-0,00088308 x^{2}, \text { com } r^{2}=0,98
$$

onde:

Y é a variável dependente (plântulas mortas); e

$\mathrm{X}$ é a variável independente (niveis de nitrogênio). 


\subsection{Massa seca de 100 sementes}

A análise da variância mostra valores de $\mathrm{F}$ significativos para cultivares e niveis de nitrogênio.

No Quadro 31 estão expostos as médias de massa seca de 100 sementes, o coeficiente de variação e a diferença mínima significativa.

Quadro 31. Médias de massa seca de 100 sementes, em gramas, para 12 tratamentos.

\begin{tabular}{lcccc}
\hline \multicolumn{5}{c}{ Cultivares } \\
\hline Níveis de N & IAC 101 & LAC 102 & LAC 242 & Médias (1) \\
\hline $\mathrm{kg} / \mathrm{ha}$ & & & $\mathrm{g}$ & \\
\hline 0 & 2,94 & 2,53 & 2,65 & 2,71 \\
50 & 2,95 & 2,64 & 2,66 & 2,75 \\
100 & 2,96 & 2,64 & 2,60 & 2,73 \\
150 & 3,05 & 2,61 & 2,60 & 2,75 \\
\hline Médias (2) & $2,97 \mathrm{a}$ & $2,60 \mathrm{~b}$ & $2,62 \mathrm{~b}$ & \\
\hline CV \% & 1,37 & & & \\
\hline D.M.S. (5\%) & 0,39 & & & \\
\hline
\end{tabular}

As médias de massa seca de 100 sementes apresentadas no quadro 31 revelam que o cultivar IAC 101 superou os cultivares IAC 102 e IAC 242, que não diferiram significativamente entre si pelo teste de Tukey $(\alpha=0,05)$.

A análise de regressão polinomial revelou efeito linear significativo para níveis de nitrogênio, dado pela equação polinomial:

$$
Y=2,721889+0,0002378 x, \operatorname{com} r^{2}=0,53
$$

onde: 
Y é a variável dependente (massa seca de 100 sementes); e

X é a variável independente (níveis de nitrogênio).

Na Figura 19 encontram-se representadas as médias de massa seca de 100 sementes, em gramas, dos cultivares IAC 101, IAC 102 e IAC 242.

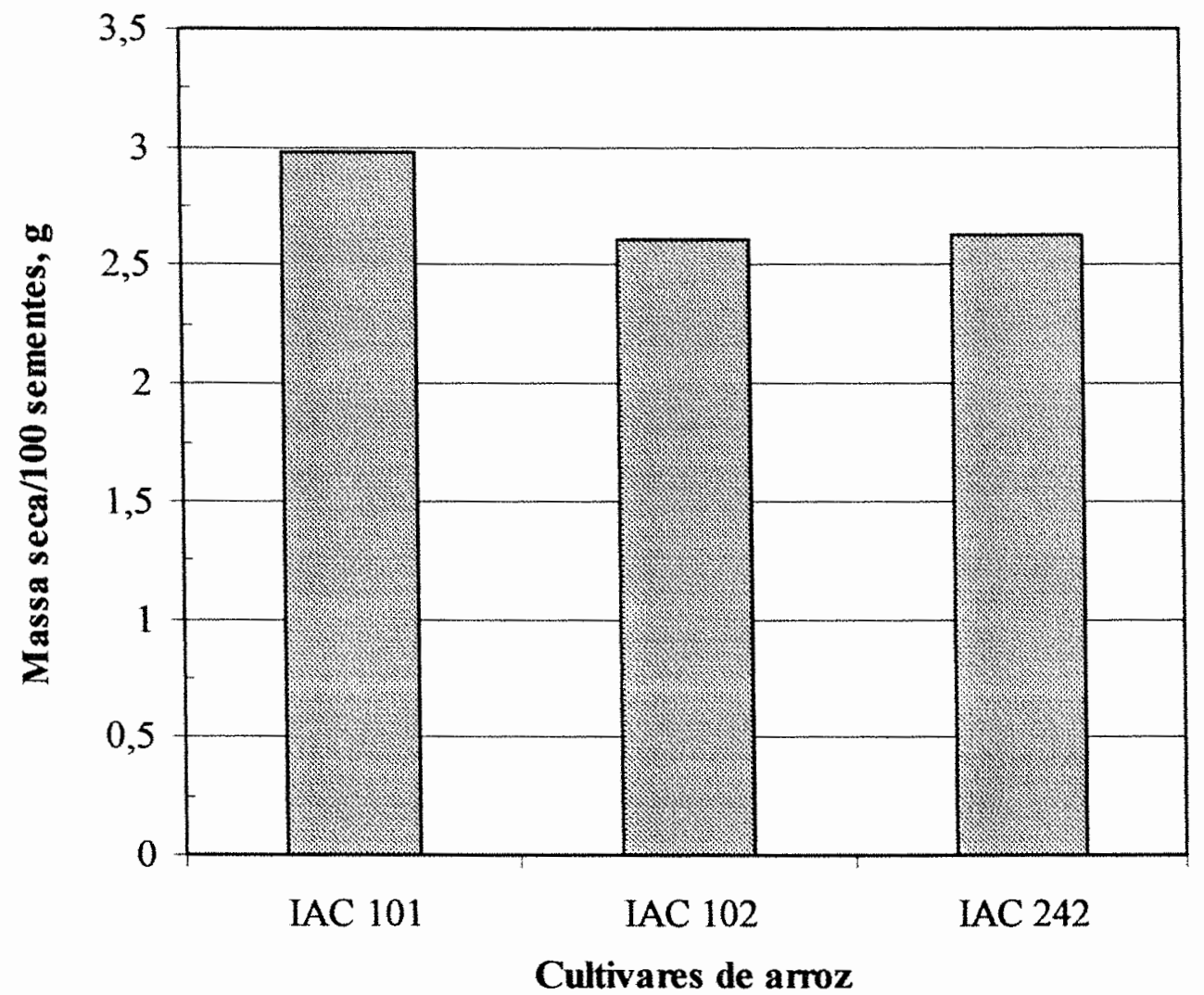

Figura 19. Médias de massa seca de 100 sementes apresentadas pelos três cultivares de arroz estudados. 


\subsection{Peso hectolítrico}

Através da análise da variância foi encontrado valor de $\mathrm{F}$ significativo para os níveis de nitrogênio.

O Quadro 32 apresenta as médias de peso hectolítrico, em gramas, coeficiente de variação e diferença mínima significativa.

A análise de regressão polinomial mostrou efeito quadrático significativo para níveis de nitrogênio, dado pela equação polinomial:

$$
Y=53,544444-0,0313333 x+0,00011111 x^{2}, \operatorname{com}^{2}=0,99
$$

onde:

Y é variável dependente (peso hectolítrico); e

X é a variável independente (níveis de nitrogênio).

Quadro 32. Médias de peso hectolítrico, em gramas, para 12 tratamentos.

\begin{tabular}{|c|c|c|c|c|}
\hline \multicolumn{5}{|c|}{ Cultivares } \\
\hline Níveis de $\mathrm{N}$ & IAC 101 & IAC 102 & IAC 242 & Médias (1) \\
\hline $\mathrm{kg} / \mathrm{ha}$ & (2. & (n- & 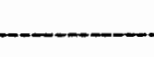 & - \\
\hline 0 & 53,66 & 53,00 & 54,00 & 53,55 \\
\hline 50 & 52,00 & 52,00 & 52,66 & 52,22 \\
\hline 100 & 51,66 & 51,66 & 51,33 & 51,55 \\
\hline 150 & 51,33 & 52,00 & 50,66 & 51,33 \\
\hline Médias (2) & $52,16 \mathrm{a}$ & $52,16 \mathrm{a}$ & $52,16 a$ & \\
\hline $\mathrm{CV} \%$ & 1,26 & & & \\
\hline D.M.S. $(5 \%)$ & 0,67 & & & \\
\hline
\end{tabular}


Os efeitos dos níveis crescentes de nitrogênio sobre o peso hectolítrico dos três cultivares, conforme as médias, encontram-se representados pela curva de resposta na Figura 20.

Observa-se pela figura 20 , que o peso hectolitrico variou inversamente aos niveis crescentes de nitrogênio, verificando-se decréscimos mais acentuados entre os níveis de 0 a $100 \mathrm{~kg}$ de $\mathrm{N} / \mathrm{ha}$, com tendência à estabilidade para níveis de nitrogênio superiores.

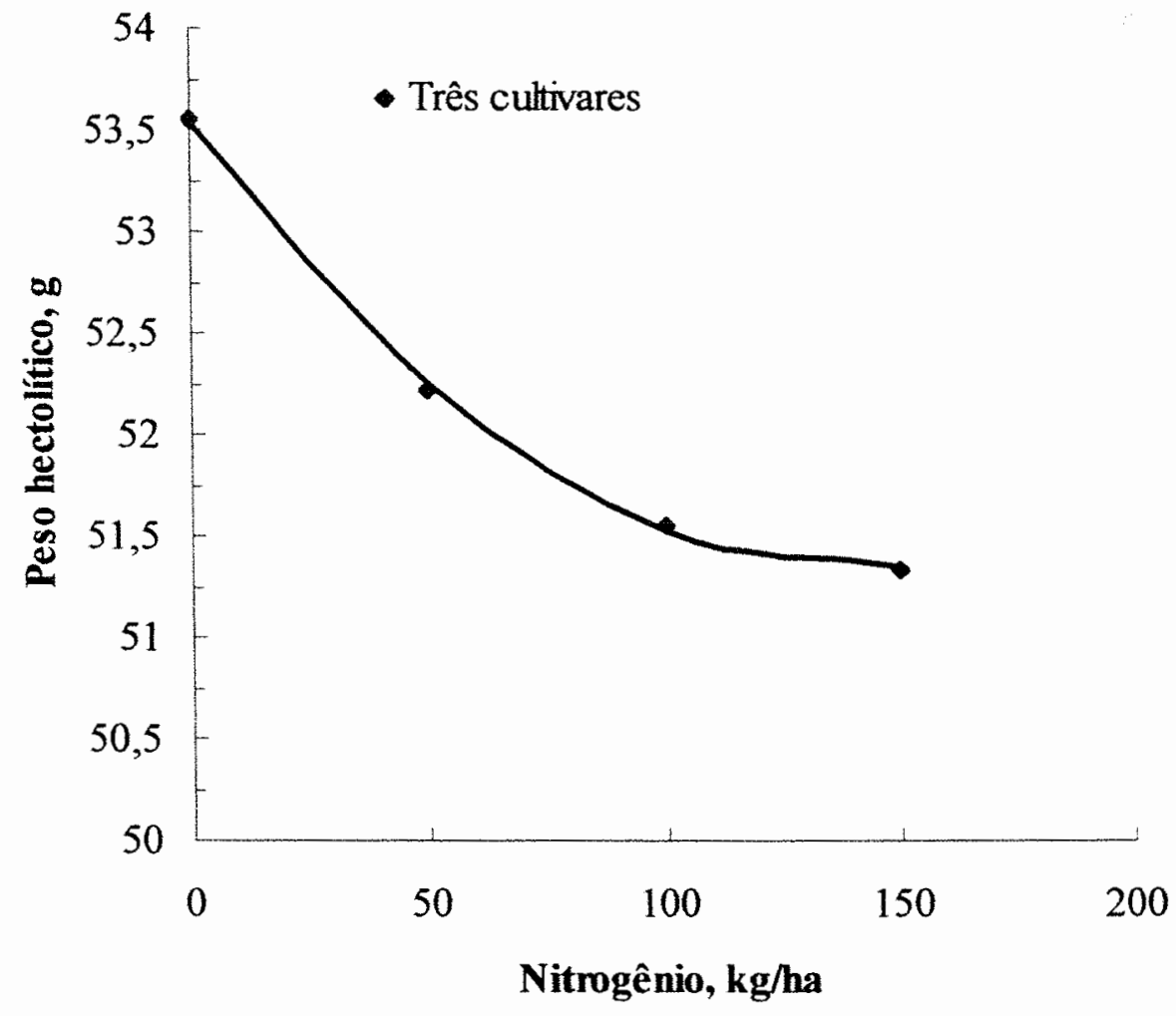

Figura 20. Curva de resposta do peso hectolítrico dos três cultivares aos quatro niveis de nitrogênio. 


\section{DISCUSSÃO}

Pela literatura consultada observou-se, de uma forma geral, que o arroz responde positivamente à fertilização nitrogenada em relação a produção de grãos, componentes da produção e estatura das plantas, encontrando-se poucas informações quanto a influência do nitrogênio sobre o ciclo do arroz, qualidade das sementes e qualidade de grãos.

Os ciclos dos três cultivares de arroz estudados, mostraram-se pouco influenciados pela fertilização nitrogenada, e os valores médios de ciclo dos cultivares, obtidos neste trabalho, são bastante inferiores aos apresentados na descrição de cultivares (Bastos et al., 1991; Bastos et al., 1993 e Schmidt et al., s.d.), provavelmente devido à fatores climáticos ocorridos nos diferentes anos em que foram realizadas as respectivas observações, ou também como efeito de diferenças entre épocas de plantio, que segundo Villela et al., ${ }^{2}$ (1987), em condições edafoclimáticas semelhantes às deste trabalho, observaram que plantios tardios (novembro-dezembro) induziram redução de ciclo aos cultivares.

Os resultados obtidos no experimento revelam que a estatura das plantas foi fortemente influenciada pela fertilização nitrogenada, confirmando a literatura consultada (Alvarenga et al., 1979; Mueller, 1980; Lopes, 1989 e Lopes et al., 1996).

\footnotetext{
${ }^{2}$ VILLELA, O.V.; SCHMIDT, N.C. \& TISSELLI FILHO, O. Comportamento de cultivares de arroz irrigado no Vale do Paraiba em diferentes épocas de plantio. III Reunião Nacional de Pesquisa de Arroz. Goiânia-GO, 1989.
} 
Os três cultivares estudados responderam positivamente em estatura, às aplicações crescentes de nitrogênio, porém apenas o cultivar IAC 102 atingiu estatura semelhante à relatada na descrição de cultivares por Bastos et. al. (1993).

A interação cultivares $x$ niveis de nitrogênio revela comportamento distinto entre os cultivares dentro dos niveis $\mathrm{N}_{1}$ e $\mathrm{N}_{2}$ de nitrogênio.

Quanto ao número de panículas $/ \mathrm{m}^{2}$, não se observou nenhum efeito da fertilização nitrogenada, contrariando os resultados encontrados na literatura (Iglesias \& Vargas, 1980; Andrade \& Amorim Neto, 1996) obtidos em experimentos de campo instalados pelos métodos de semeadura em linha em solo drenado e transplantio manual de mudas, que contribuem para existência de espaços vazios no início do desenvolvimento das plantas.

No experimento em questão, provavelmente a distribuição uniforme das sementes pré-germinadas sobre o solo e a elevada densidade de sementes por unidade de área adotada, suprimiram a formação de perfilhos produtivos.

As variáveis comprimento de panícula, número de grãos por panícula, número de grãos granados por panícula e número de grãos fanados por panícula, foram influenciadas positivamente nos três cultivares estudados, pelos acréscimos de níveis de nitrogênio aplicados, conforme se constata através da literatura consultada (Iglesias \& Vargas, 1980; Carvalho et al., 1995; Lopes et al. 1996; Bernal et. al., 1985 e Mueller, 1980).

Comparando os resultados apresentados nos quadros $6,7,8$ e 9 , verificou-se que houve correspondência entre comprimento de panícula e número de grãos por panícula. Como exemplo o cultivar IAC 102, com maior comprimento de 
panícula que os demais cultivares, também apresentou maior número de grãos por panícula, número de grãos granados por panícula e número de grãos fanados por panícula.

O peso de grãos por panícula, peso de grãos granados por panícula e peso de grãos fanados por panícula foram influenciados positivamente pelos acréscimos de níveis de nitrogênio, revelando comportamento semelhante ao apresentado pelas variáveis número de grãos por panícula, número de grãos granados por panícula e número de grãos fanados por panícula, incluindo-se as comparações entre as médias dos três cultivares.

$\mathrm{O}$ peso de 100 grãos mostrou-se influenciado positivamente pela fertilização nitrogenada, principalmente para os níveis de nitrogênio entre 0 e $50 \mathrm{~kg}$ de $\mathrm{N} / \mathrm{ha}$, sendo que a partir de $150 \mathrm{~kg}$ de $\mathrm{N} / \mathrm{ha}$ observou-se decréscimo para esta variável. Esses dados estão conflitantes com os resultados obtidos por (Iglesias \& Vargas, 1980), que encontraram resposta positiva em peso de 100 grãos somente para aplicação de $150 \mathrm{~kg}$ de $\mathrm{N} / \mathrm{ha}$, com os obtidos por Dario et al. (1989), que não constataram qualquer efeito, e por outros autores, que observaram decréscimo no peso de 100 grãos com o incremento de níveis de nitrogênio (Carvalho et al., 1995; Mueller, 1980).

Observou-se maiores variações no peso de 100 grãos, nas médias dos cultivares do que nos niveis de nitrogênio, sugerindo que esta caracteristica está mais fortemente ligada ao cultivar, conforme se observa na descrição dos cultivares (Bastos et al., 1991; Bastos et al., 1993 e Schmidt et al., s.d.). 
Quanto ao efeito da fertilização nitrogenada sobre as dimensões dos grãos de arroz, verificou-se que o comprimento mostrou efeito quadrático com as maiores variações ocorridas entre os niveis $\mathrm{N}_{0}$ e $\mathrm{N}_{1}$ de nitrogênio e a largura com efeito linear, não sendo observado qualquer efeito do nitrogênio sobre a espessura dos grãos dos cultivares estudados.

Os ganhos obtidos no comprimento e largura dos grãos revelaram-se modestos e discordantes da literatura consultada, na qual se constatou não haver efeito significativo de acréscimos de niveis de nitrogênio sobre as dimensões dos grãos (Silva \& Brandão, 1987) e as diferenças observadas entre as médias, praticamente foram devido aos cultivares.

Os efeitos positivos da adubação nitrogenada sobre o rendimento de grãos do arroz irrigado no Vale do Paraiba, têm sido demonstrados a partir dos primeiros experimentos instalados na região utilizando adubos químicos sintéticos (Leite et al., 1970a; Leite et al., 1970b; Leite et al., 1970c; Schmidt \& Gargantini, 1963 e Hiroce et al., 1985).

Neste estudo o rendimento de grãos apresentou alta significância para os niveis de nitrogênio, não se observando diferenças significativas entre cultivares, cujas médias contidas no quadro 17 são inferiores àquelas apresentadas na descrição de cultivares (Bastos et al., 1991; Bastos et al., 1993 e Schmidt et al., s.d.).

O comportamento produtivo dos cultivares estudados foi bastante influenciado por niveis crescentes de nitrogênio, com a maior produção de grãos correspondendo ao nível máximo ( $150 \mathrm{~kg}$ de $\mathrm{N} / \mathrm{ha}$ ), embora se tenha observado na literatura (Lopes et al., 1996 e Spanu \& Pruneddu, 1997), que valores máximos de 
produção de grãos tenham sido atingidos com niveis inferiores à $100 \mathrm{~kg}$ de N/ha (Alvarenga et al., 1979 e Mueller, 1980).

Pela análise dos componentes da produção estudados, verificou-se que o número de grãos granados por panícula foi o componente da produção que mais contribuiu para os incrementos de produção de grãos, obtidos com os acréscimos de niveis de nitrogênio, entretanto, dividindo-se as médias de grãos granados por panícula, referentes aos 4 niveis de nitrogênio do quadro 8 , pelas respectivas médias de grãos fanados por panícula do quadro 9 , verificou-se que houve aumento de grãos fanados por panícula em relação aos grãos granados, para incremento de níveis de nitrogênio o que deve ter contribuído para as reduções de ganhos de rendimento de grãos para níveis crescentes de nitrogênio, observadas tanto no quadro 17 , como na figura 10 , cuja curva mostra tendência de estabilidade de produção de grãos para nível de nitrogênio superior ao nível máximo estudado.

A redução na eficiência de utilização de nitrogênio, semelhante entre os três cultivares estudados para tratamentos superiores a $100 \mathrm{~kg}$ de $\mathrm{N} / \mathrm{ha}$, representada pelo parâmetro $E_{\mathrm{N}}(\mathrm{kg}$ de grãos/kg N) também foi constatada por diversos autores (Soares et al., 1994; Sudjadi et al., 1987 e Valdivieso et al., 1980).

O rendimento de grãos no beneficiamento, um dos mais relevantes fatores de qualidade do arroz para consumo, mostrou ser influenciado tanto pela fertilização nitrogenada como também pela característica varietal. Os efeitos lineares positivos do peso de grãos inteiros beneficiados e linear negativo do peso de grãos quebrados beneficiados, obtidos pelos incrementos nos níveis de nitrogênio aplicados ao experimento são discordantes dos encontrados na literatura consultada (Bernal et al., 
1985 e Silva \& Brandão, 1987), cujos resultados de grãos inteiros no beneficiamento, revelam modestos ganhos de qualidade, como também diferenças não significativas para nível crescentes de nitrogênio.

Observa-se no quadro 18 que, nos níveis $N_{0}$ e $N_{1}$ de nitrogênio, os cultivares IAC 101 e IAC 102 apresentam pesos de grãos inteiros no beneficiamento inferiores ao IAC 242, mostrando resultados mais próximos nos níveis $\mathrm{N}_{2}$ e $\mathrm{N}_{3}$, concordando com aqueles apresentados na descrição dos cultivares (Bastos et al., 1991; Bastos et al., 1993 e Schmidt et al., s.d.).

Os resultados de peso de grãos quebrados no beneficiamento, contidos no quadro 19, cujos comportamentos estão inversamente associados ao peso de grãos inteiros no beneficiamento, também refletem efeito positivo de acréscimos de níveis de nitrogênio sobre a qualidade industrial do arroz. Os cultivares IAC 101 e IAC 102 que apresentaram maiores médias de peso de grãos quebrados nos níveis $N_{0}$ e $N_{1}$ de nitrogênio, apresentaram maiores reduções para acréscimos de níveis de nitrogênio que o cultivar IAC 242.

As produções de grãos inteiros e quebrados no beneficiamento, apresentadas nos quadros 21 e 22 , respectivamente, refletem o comportamento das variáveis peso de grãos inteiros e peso de grãos quebrados no beneficiamento, respectivamente. Dessa forma o peso de grãos inteiros no beneficiamento e a produção de grãos em casca, por unidade de área, são componentes importantes para o sucesso econômico da cultura do arroz.

As médias de plântulas normais, plântulas anormais e plântulas infectadas, apresentadas nos quadros 23,24 e 25 respectivamente, revelam que a germinação não 
foi influenciada pelo nitrogênio, havendo diferenças significativas apenas entre cultivares.

$\mathrm{Na}$ análise do vigor das sementes, pelo teste de envelhecimento rápido, não foi constatada significância para qualquer causa de variação em relação às médias de plântulas normais e plântulas infectadas (quadros 27 e 29 respectivamente). As médias de plântulas anormais e plântulas mortas, (quadro 28 e 30) apresentaram significância variando inversamente em relação à niveis crescentes de nitrogênio. Comparando-se as médias do quadro $29 \mathrm{com}$ as dos quadros 28 e 30 , verifica-se que houve uma compensação numérica dos efeitos observados sobre as médias, resultando na não influência do nitrogênio sobre o vigor das sementes.

Dessa maneira os resultados da avaliação fisiológica das sementes, germinação e vigor, estão de acordo com os observados na literatura por (Costa, 1978).

A massa de 100 sementes apresentou efeito altamente significativo, revelando ser componente de qualidade fisica das sementes, com forte influência de origem genética. De comportamento semelhante ao peso de 100 grãos, apresenta relação positiva com acréscimos de níveis de nitrogênio, não tendo sido encontrada na literatura consultada nenhuma referência a este parâmetro estudado.

O peso hectolítrico das sementes mostrou ser inversamente influenciado por niveis crescentes de nitrogênio, apresentando efeito quadrático. Não se encontrando qualquer citação referente à esta variável na literatura consultada, considera-se que a explicação mais plausível para esse comportamento seja dada pelo aumento nas dimensões, comprimento e largura dos grãos, que resultou em maiores espaços vazios entre os grãos. 
Os resultados obtidos neste trabalho sugerem que sejam realizadas as seguintes pesquisas complementares:

a) Determinação da eficiência de utilização do nitrogênio no desenvolvimento das plantas e produção de grãos, dos cultivares de arroz irrigado mais amplamente utilizados no Estado de São Paulo.

b) Influência do nitrogênio sobre a qualidade industrial e culinária do arroz.

c) Direcionar programas de melhoramento para seleção de plantas de arroz portadoras de panículas de maior comprimento, com maior número de ramificações e de grãos, que os cultivares de irrigado recomendados para plantio. 


\section{CONCLUSÃO}

Os resultados obtidos neste estudo permitem concluir:

a) A fertilização nitrogenada influencia positivamente a estatura das plantas, o número e o peso de grãos por panícula, o peso de 1000 grãos, as dimensões dos grãos, a produção de grãos e o rendimento de grãos no beneficiamento.

b) O número de grãos granados por panícula é o componente de produção que mais influencia no aumento de rendimento de grãos.

c) As maiores respostas à fertilização nitrogenada ocorre entre os níveis 0 e $50 \mathrm{~kg}$ de $\mathrm{N} / \mathrm{ha}$, e para níveis acima de $100 \mathrm{~kg}$ de N/ha ocorre redução de eficiência de utilização de N.

d) O ciclo dos cultivares e as características fisiológicas das sementes não são influenciadas pela fertilização nitrogenada. 


\section{REFERÊNCIAS BIBLIOGRÁFICAS}

ALVARENGA, M.A.R.; AQUINO, A.R.L. de; STONE, L.F.; AJIMURA, G.M.; SILVEIRA FILHO, A. Espaçamento, densidade de semeadura e controle de ervas daninhas na resposta de arroz irrigado ao nitrogênio. Pesquisa Agropecuária Brasileira, v.14, n.4, p.377-385, Out. 1979.

ANDRADE, W.E. de B.; AMORIN NETO, S. Influência da adubação nitrogenada sobre o rendimento e outros parâmetros de duas cultivares de arroz irrigado na Região Norte Fluminense. Ciência e Agrotecnologia, v.20, n.3, p.293-300, 1996. Resumo em CAB Abstracts on CD-ROM, 1996-98.

BASTOS, C.R.; SOAVE, J.; MELO DE CASTRO, L.H.S.; AZZINI, L.E.; SAKAI, M.; VILLELA, O.V.; TISSELLI FILHO, O. \& GALLO, P.B. IAC 101: Novo cultivar de arroz para o Estado de São Paulo. Campinas: Instituto Agronômico, 1991. (Folder)

BASTOS, C.R.; SOAVE, J.; SAES, L.A.; AZZINI, L.E.; VILLELA, O.V.; TISSELLI FILHO, O. \& GALLO, P.B. IAC 102: novo cultivar de arroz para o Estado de São Paulo. Campinas: Instituto Agronômico, 1993. (Folder).

BERNAL, R.J.H.; CASTILLO, R.D. del; MUÑOZ, B.D. Influencia de la arquitetura de la planta de arroz (Oriza sativa L.) y algumas practicas culturales em el rendimento y calidad. Acta Agronômico, v.35, n.1, p.23-33, Eng./mar. 1985.

BRASIL. Ministério da Agricultura. Divisão de Sementes e Mudas. Regras para análise de sementes. Brasília: SNDA/DNPV/CLV. 1992. 365p. 
CANTARELLA, H.; SILVA, N.M. da; ESPIRONELO, A. et al. Avaliação agronômica de fertilizantes nitrogenados. EMPRESA DE PESQUISA AGROPECUÁRIA. Relatório Bienal. 1984-1985. Convênio EMBRAPA/ PETROFÉRTIL. Brasília: EMBRAPA, 1986. p.47-58.

CARVALHO, G.J. de; CARVALHO, J.G. de; OLIVEIRA, P.S.R. de; SOARES, A.A. Efeito de diferentes níveis de nitrogênio nas características agronômicas de quatro cultivares e uma linhagem de arroz (Oriza sativa L.). Ciência e Prática, v.19, n.4, p.390-396, Out./Dez. 1995.

CENTRO INTERNACIONAL DE AGRICULTURA TROPICAL. Sistema de Evaluación estándar para arroz. Cali: CIAT, 1983. 61p.

CENTRO INTERNACIONAL DE AGRICULTURA TROPICAL. Latencia y pregerminacion de las semillas de arroz. Cali: CIAT, 1978. 30p.

CHABARIEBERRY, D.; MARTINS, S.S. Arroz. Prognóstico Agrícola. São Paulo. v.2, p.161-168, 1998.

COORDENADORIA DE ASSISTÊNCIA TÉCNICA INTEGRAL (CATI). Arroz - Recomendações técnicas para o Estado de São Paulo. Campinas, 1996. 73p. (Documento técnico, 100).

COSTA, N.P. da. Influência da adubação nitrogenada sobre a qualidade fisiológica de sementes de quatro cultivares de arroz. Pelotas, 1978. 48p. Dissertação (M.S.) Universidade Federal de Pelotas.

DARIO, G.J.A.; DARIO, P.W.; ONODA, S.M.; RIBEIRO, R.C.S.; VIEIRA, J.V. Efeitos de doses e épocas de aplicação de nitrogênio em cobertura, na cultura do arroz (Oryza sativa L.) irrigado, cultivado em área recém sistematizada. In: REUNIÃo DA CULTURA DO ARROZ IRRIGADO, 18., Porto Alegre, 1989. Anais. Porto Alegre: IRGA, 1989. p.202-209. 
DELOUCHE, J.C.; BASKIN, C.C. Accelerated aging techniques for predicting the relative storability of seed lots. Seed Science Technology, Zurich, v.1, n.2, p.427-452, 1973.

FAGERIA, N.K.; BABOSA FILHO, M.P. Avaliação preliminar de cultivares de arroz irrigado para maior eficiência de utilização de nitrogênio. Pesquisa Agropecuária Brasileira, v.17, n.12, p.1707-1712, Dez. 1982.

FAGERIA, N.K. Adubação e nutrição mineral da cultura do arroz. Goiânia: Editora Campus, 1984. 341p.

FERNANDES, M.S. Efeitos de fontes e níveis de nitrogênio sobre a absorção e assimilação de N em arroz. Revista Brasileira de Fisiologia Vegetal, v.2, n.1 p. 1-6, 1990.

FERRAZ JÚNIOR, A.S. de L.; SOUZA, S.R. de; FERNANDES, S.M.; ROSSIELLO, R.O.P. Eficiência do uso de nitrogênio para produção de grão e proteína por cultivares de arroz. Pesquisa Agropecuária Brasileira, v.32, n.4, p.435-442, Abr. 1997.

FURLANI, P.R.; BATAGLIA, O.C.; FURLANI, A.M.C.; AZZINI, L.E. \& SCHMIDT, N.C. Composição química inorgânica de três cultivares de arroz. Bragantia, v.36, n.8, p.435-442, 1977.

FURLANI, A.M.C.; BATAGLIA, O.C.; AZZINI, L.E. Comportamento diferencial de linhagens de arroz na absorção e utilização de nitrogênio em solução nutritiva. Revista Brasileira de Ciência do Solo, v. 10, n.1, p.51-9, Jan/Abr. 1986.

HEENAN, D.P.; BACON, P.E. Effect of nitrogen fertilizer timing on crop growth and nitrogen use efficiency by diferente rice varieties. In: THE INTERNATIONAL NETWORK ON SOIL FERTILITY AND FERTILIZER EVALUATION FOR RICE, New South Wales, 1985. Efficiency of nitrogen fertilizers for rice. Manila: IRRI, 1987. p.97-105. 
HIROCE, R.; FURLANI, A.M.C.; GALLO, J.R.; SOUZA, D.M.; IGUE, T.; SCHMIDT, N.C. \& LAVORENTI, A. Estudos nutricionais em arroz "IAC-841", "IAC-436" e "IAC-47" em diferentes estádios de crescimento e níveis de adubação N, P e K. Campinas, Instituto Agronômico, 1985, 27p. (Boletim Científico, 5).

IGLESIAS, E.N. \& VARGAS, Z.J.P. Respuesta del arroz (O. sativa L.) var. CICA-8 a la aplicación fraccionada de nitrogênio em condiciones de campo. Acta Agronomica. v.30, n.1/4, p.49-60, Feb./Dic. 1980.

INSTITUTO DE ECONOMIA AGRICOLA. Informações Estatísticas da Agricultura - Anuário IEA 1997, São Paulo, v.9, n.1, 1998. 176p.

LEITE, ; GARGANTINI, H. \& HUNGRIA, S.L. Efeito das adubações nitrogenada e fosfatada em cultura de arroz, em condições de várzea irrigada. Bragantia. v.29, n.11, p.115-125, 1970.

LEITE, N.; GARGANTINI, H.; GOMES, A.G.; IGUE, T. Efeito de diferentes fertilizantes nitrogenados no aumento da produtividade do arroz irrigado. Bragantia, v.29, p.263-272, 1970.

LEITE, N.; GARGANTINI, H.; HUNGRIA, L.S.; IGUE, T. Efeitos do nitrogênio, fósforo, calcário e micronutrientes em cultura de arroz irrigado no Vale do Paraiba. Bragantia, v.20, p.273-285, 1970.

LOPES, M.S. Fontes e épocas de aplicação de nitrogênio em arroz-parcelas demonstrativas. In: REUNIÃO DA CULTURA DO ARROZ IRRIGADO, 18., Porto Alegre, 1989. Anais. Porto Alegre: IRGA, 1989. p.210-218.

LOPES, S.I.G.; BARROS, J. de A.I. de; OLIVEIRA, M.A.B. Doses e épocas de aplicação de nitrogênio para a cultivar IRGA 416. Lavoura Arrozeira, v.46, n.408, p.6-7, Maio/Jun. 1993.

LOPES, S.I.G.; LOPES, M.S.; MACEDO, V.R.M. Curva de resposta à aplicação de nitrogênio para quatro genótipos de arroz irrigado. Lavoura Arrozeira. v.49, n.425, p.3-6, Jan./Fev. 1996. 
MARCOS FILHO, J.; CÍCERO, S.M.; SILVA, W.R. Avaliação da qualidade de sementes. Piracicaba: FEALQ, 1987. 230p.

MUELER, S. Influência da adubação nitrogenada sobre o rendimento e outros parâmetros de três cultivares de arroz irrigado (Oryza sativa L.). Pelotas, 1980. 191p. Dissertação (M.S.) - Universidade Federal de Pelotas.

PERPÉTUO, A. da S.; BRASIL SOBRINHO, M. de O. da; GUIMARÃES, G. Época de aplicação do nitrogênio e seu efeito sobre a produtividade do arroz irrigado (Oryza sativa L.). Revista de Agricultura, v.64, n.2, p.163-177, Out. 1989.

RAZERA, L.F.; LAGO, A.A.; MAEDA, J.A.; ZINK, E.; GODOY JÚNIOR, G.; TELLA, R. Armazenamento de sementes de arroz e milho em diferentes embalagens e localidades paulistas. Bragantia, Campinas, v.45, n.2, p.337-352, 1986.

SCHMIDT, N.C. \& GARGANTINI, H. Adubação nitrogenada para arroz em solos argilosos de várzea. Separata de Bragantia, v.22, p.367-372, 1963.

SCHMIDT, N.C. \& GARGANTINI, H. Aplicação de nitrogênio em cobertura, em cultura do arroz. Bragantia, v.45, n.5, p.57-63, 1966.

SCHMIDT, N.C.; AZZINI, L.E.; TISSELLI FILHO, O.; VILLELA, O.V.; SOAVE. J.; BASTOS, C.R.; GALLO, P.B.; SAKAI, M. \& TORRES, S.G. IAC- 238 e IAC-242: Cultivares promissores para o Estado de São Paulo. Campinas: Instituto Agronômico, s.d. (Folder).

SILVEIRA, J.A. da; MACHADO, E.C. Mobilização de nitrogênio e de carboidratos durante o desenvolvimento de panículas de duas cultivares de arroz. Revista Brasileira de Fisiologia Vegetal, v.2, n.2, p.37-46, 1990.

SILVA, P.S.L. e; BRANDÃO, S.S. Rendimento no beneficiamento e translucidez de grãos de cultivares de arroz em função de níveis de nitrogênio. Pesquisa Agropecuária Brasileira, v.22, n.9/10, p.943-949, Set./Out. 1987. 
SOARES, A.A.; CARVAlHO, J.G.; CARVALHO, G.J. de; FONSECA, J.R.; OLIVEIRA, P.S.R. de. Diferenças varietais na absorção, translocação e exportação de nitrogênio em arroz (Oryza sativa L.) de sequeiro. Ciência e Prática, v.18, n.3, p.248-257, Jul./Set. 1994.

SPANU, A.; PRUNEDDU, G. Effect of increasin nitrogen rates on the yeld o sprinkler irrigated rice (Orysa sativa L.). Agricoltura Mediterranea, v.127, n.4, p.379-387, 1997. /Resumo em CAB Abstracts on CD-ROM, 1996-98/

SUDJADI, M.; PRAWIRASUMANTRI, Y.; WETSELAAR, R. Nitrogen Fertilizer Efficiency in lowland rice in Indonesia. In: PROCEEDINGS OF THE MEETING OF THE INTERNATIONAL NETWORK ON SOIL FERTILITY AND FERTILIZER EVALUATION FOR RICE, New South Wales, 1985. Efficiency of nitrogen fertilizers for rice. Manila: IRRI, 1987. p.106-117.

VALDIVIESO, L.F.S.; TENORIO LOURIDO, G.A.; GONZALEZ FRANCO, J.A. Desarrollo y rendimento de dos variedades de arroz (Oriza sativa L.) bajo dos distancias de transplante y tres niveles de nitrogenio. Acta Agronomica, v.30, n.44, p.61-70, Feb./Dic. 1980.

WETZEL, C.T. Contribuição ao estudo da aplicação do teste de envelhecimento visando a avaliação do vigor em sementes de arroz (Oryza sativa L.), trigo (Triticum aestivum L.) e de soja \{Glycine $\max (L)$ Merril\}. Piracicaba, 1972. 116p. Tese (Mestrado). Escola Superior de Agricultura "Luiz de Queiroz"/USP. 